PARADOSIS

Contributions to the History of Early Christian Literature and Theology XXIII

Sr. DOMINIQUE CUSS, F. C. J.

\title{
IMPERIAL CULT AND HONORARY TERMS IN THE NEW TESTAMENT
}


PARADOSIS is intended as a series of studies in ancient Christian literature and theology. The Greek term, already familiar to the earliest Christian writers, has been adopted as a title since it is convenient for quotation and reference, while at the same time serving to cover contributions in various languages. It implies, furthermore, both a principle and a programme. Christian theology is by its nature rooted in the past. Only in so far as it remains in living contact therewith is it capable of further growth. Hence any study, however unassuming, that throws light on tradition or its sources becomes by the very fact a contribution to the theology of the present.

Othmar Perler.

Fribourg, Switzerland. 
PARADOSIS

Contributions to the History of Early Christian Literature and Theology XXIII

Sr. DOMINIQUE CUSS, F.C.J.

\section{IMPERIAL CULT AND HONORARY TERMS IN THE NEW TESTAMENT}


Publication subsidized by the Fribourg University Council Fribourg Switzerland

(C) 1974 by the Fribourg University Press, Fribourg Switzerland

Imprimerie St. Paul, Fribourg 


\section{ACKNOWLEDGMENTS}

I wish to express my appreciation for the interest and help of Mme Lilly Kahil, Professor of Ancient History at the University of Fribourg/Switzerland, during my years of study under her guidance. My thanks are also due to Révérend Père C. Spicq, O. P. for his helpful criticism and suggestions. I thank Mr. P. Devambez, Conservateur-en-Chef du Département des Antiquités grecques et romaines au Musée du Louvre, Dr. R. Higgins and the members of the Department of Greek and Roman Antiquities at the British Museum, and Professor T. Zawadzki, of Fribourg University.

I am grateful to all those who encouraged and helped me, especially during the months of research at the British Museum, and to P. and K. Gill and J. T. McGrath, M. S. F. S. for reading and correcting my work.

The photos of the coins and the "Apotheosis Diptych" are reproduced with the permission of the Trustees of the British Museum. 


\section{PLAN}

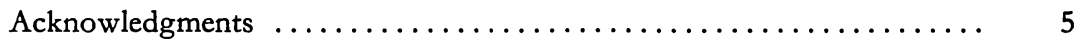

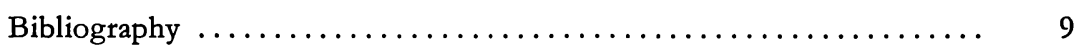

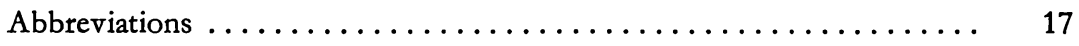

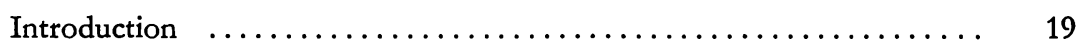

I. The Sources of the Imperial Cult and Its Early Development ........ 23

a) Divine Honours in the Hellenistic East $\ldots \ldots \ldots \ldots \ldots \ldots . \ldots \ldots$

b) Divine Honours in the Roman Republic ............ 27

c) Divine Honours in the Early Empire ............. 30

II. New Testament Implications towards the Roman Empire and the Emperor. 36

a) The Attitude of Christ towards the Roman Empire ...... 36

b) The Attitude of St. Paul towards the Emperor ........... 39

c) The Attitude of Pilate and the Significance of the Expression 'Friend of Caesar' .......................... 44

III. References to the Imperial Cult in the Apocalypse............. 50

1. The 'Blasphemous Titles' of the First Beast ............. 50

a) The Title 'Kúpros' in Imperial and Christian Usage ....... 53

b) ' $\Sigma \omega \tau \eta \dot{p} \rho$ ' - Its Hellenistic and Christian Meaning ........... 63

c) The Title of 'Divi Filius' $\ldots \ldots \ldots \ldots \ldots \ldots \ldots \ldots \ldots \ldots . \ldots \ldots \ldots \ldots$

2. Acclamations - a Possible Interpretation of the Term 'Blasphemous Titles' as Used in the Apocalypse ................. 74

3. The Legend of 'Nero Redivivus' $\ldots \ldots \ldots \ldots \ldots \ldots \ldots \ldots \ldots . \quad 88$

IV. The Significance of the 'Second Beast' of the Apocalypse and Its Implications

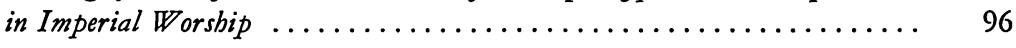

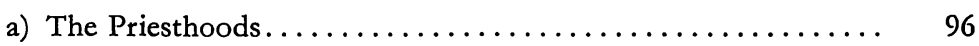

b) The Significance of the Term 'Image of the Beast' and the Importance of Statues in Imperial Cult Worship $\ldots \ldots \ldots \ldots$ 
1. The Notion of 'Ascension' as an Expression of Glorification

2. The Profane and Religious Implications of the Term 'E $\pi \iota \varphi \alpha$ ' $\varepsilon\llcorner\alpha$ '

VI. Persecution in Relation to the Imperial Cult ............... 145

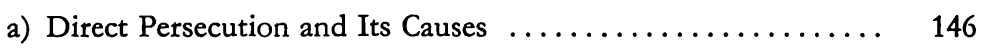

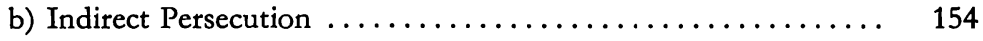

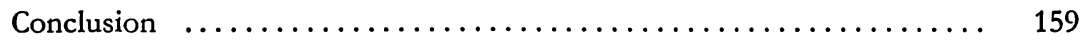

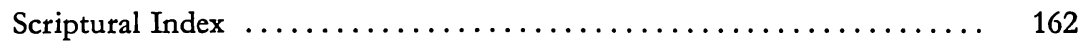

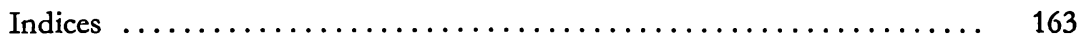

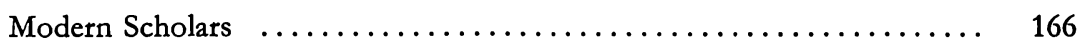




\section{BIBLIOGRAPHY}

\section{A. Literary Sources}

Appian, Roman History, LCL, tr. H. White. 4 vols. 1955-1958.

Arrian, Anabasis, tr. E. J. Chinnock (The Greek Historians. Vol. II, ed. F. R. Godolphin) New York, 1942.

S. Aurelius Victor, De Caesaribus, ed. Fr. Pichlmayr. Leipzig, 1961.

Dro Cassius, Roman History. LCL. in 9 volumes, tr. E. Cary, 1955.

Drodorus of Sicily, History. LCL, tr. R. M. Geer, 1954.

Dionysius of Halicarnassus, Roman Antiquities, LCL, in 7 vols, tr. E. Cary, 1953.

Eusebius, The History of the Church from Christ to Constantine, tr. G. A. Williamson. New York, 1966.

Josephus, Jewish Antiquities, tr. R. Marcus. LCL, 1961.

- - Jewish War. LCL, tr. H. Thackeray, 1957.

Lrvy, Roman History, in 14 vols. LCL, tr. B. O. Foster, 1957.

Philo, Legatio ad Gaium, ed. M. Smallwood. Leiden, 1961.

Pliny, Natural History. LCL, tr. H. Rackham, 1958.

Plutarch, The Parallel Lives, LCL, tr. B. Perrin. Alexander VII, 1958. Antony IX, 1959. Caius Gracchus X, 1959. Caius Marius IX, 1959. Cato the Younger VIII, 1959. Camillus \& Cato Major II, 1959. Demetrius IX, 1959. Lysander IV, 1959. Romulus I, 1959. Titus Flamininus X, 1959.

Polybius, Histories. LCL, tr. W. R. Paton, 1954.

Seneca, L'Apocoloquintose du divin Claude, éd. et tr. par R. Waltz. Paris, 1934.

Suetonius, Vie des douze Césars. tr. H. Ailloud. Paris, 1931.

TAcitus, Annales, ed. C. D. Fisher. Oxford, 1953.

Tertullian, Apologeticus. LCL, tr. T. R. Glover. London, 1931.

Zonaras, Epitome Historiarum. Leipzig, 1868.

\section{B. Literature for Archaeological Aspects}

Babelon, E., Catalogue des camées antiques et modernes de la Bibliothèque Nationale. Paris, 1897.

Charbonneaux, J., L'art au siècle d'Auguste. Paris / Lausanne, 1948.

Charles-Picard, G., L'art romain. Paris, 1962.

Curtius, L., Ikonographische Beiträge zum Porträt der römischen Republik und der Julisch-Claudischen Familie. RM I (1948) pp. 53-94.

Dalton, O. M., Catalogue of Ivory Carvings of the Christian Era. London, 1909. 
Delbrück, R., Die Consulardiptychen. Berlin / Leipzig, 1929.

Fossing, P., Catalogue of the Antique Engraved Gems and Cameos. Copenhagen, 1929.

Furtwaengler, A., Die antiken Gemmen. Vols. I-III. Amsterdam/Osnabrück, 1964-65.

Graeven, H., Heidnische Diptychen. RM XXVIII (1913) pp. 198-304.

Jucker, H., Auf den Schwingen des Göttervogels. JBM XXXIX-XL (1959-60).

Kitzinger, E., Early Medieval Art in the British Museum. London, 1963.

Maskell, A., Ivories. London, 1905.

Middleton, J. H., The Engraved Gems of Classical Times. Cambridge, 1891.

Moretri, G., Ara Pacis Augustae. Romae, 1948.

Peirce, H., Tyler, R., L'art byzantin. T. I. Paris, 1932.

Rodenwaldt, G., Kunst um Augustus. Berlin, 1942.

Ryberg, I. Scott, Rites of the State Religion in Roman Art. MAAR XXII, 1955.

St. Clair, A., The Apotheosis Diptych. The Art Bulletin XLVI (1964) p. $207 \mathrm{ff}$.

Toynbee, J., The Ara Pacis Re-considered. PBA XXXIX (1953) pp. 67-95.

- - The Ara Pacis Augustae. JRS LI (1961) pp. 153-156.

VolвACH, W. F., Elfenbeinarbeiten der Spätantike und des früben Mittelalters. Mainz, 1952.

WeSSEL, K., Eine Gruppe oberitalischer Elfenbeinarbeiten. JdI LXIII-LXIV (1950) pp. 143-146.

Weinstock, S., Pax and the Ara Pacis. JRS L (1960) pp. 44-58.

Wheeler, Sir M., Roman Art and Architecture. New York, 1964.

WILL, E., Sur quelques figures de la gemma augustéenne. Latomus XIII (1954) p. $597 \mathrm{ff}$.

\section{Numismatic Evidence}

Abaecherli, A. L., Imperial Symbols on Certain Flavian Coins, CLPh XXX(1935) pp. 131-140.

Alföldi, A., The Main Aspects of Political Propaganda on the Coinage of the Late Republic. Oxford, 1956.

Grunau, G., Inscbriften und Darstellungen römischer Kaisermünzen von Augustus bis Diocletian. Biel, 1899.

Mattingly, H., Coins of the Roman Empire in the British Museum. London, 1930.

Matringly, H., Sydenham, E., The Roman Imperial Coinage. London, 1923 repr. 1948.

Strack, P. L., Die Reichsprägung zur Zeit des Antoninus Pius (Untersuchungen zur römischen Reichsprägung. Teil III) Stuttgart, 1937.

\section{Inscriptions, Papyri, and Ostraka}

Bureth, P., Les titulatures impériales dans les papyrus, les ostraca et les inscriptions d'Egypte. Bruxelles, 1964.

Dessau, H., Inscriptiones latinae selectae. Berlin, $1892 \mathrm{ff}$.

Ehrenberg V. \& Jones, A. H. M., Documents Illustrating the Reigns of Augustus and Tiberius. Oxford, $1955^{2}$.

Fraenkel, M., Die Inschriften von Pergamon. Berlin, 1895. 
McNeILl, G., Latin Historical Inscriptions Illustrating the History of the Early Empire. London, 1938.

Meyer, P., Griechische Texte aus Agypten. Berlin, 1916.

Newton, C. T., Collection of Ancient Greek Inscriptions in the British Museum. Oxford, 1874.

Paton, W. R. \& Hicks, E. L., The Inscriptions of Cos. Oxford, 1891.

SEYRIG, H., Inscriptions de Gythion. RA XXIX (1929) pp. 84-106.

Wenger, L., Griechische Inschriften zum Kaiserkult und zum Grabrecht. ZRG XLIX (1929) pp. 308-328.

Wilcken, U., Griechische Ostraka. Leipzig \& Berlin, 1899.

\section{E. Modern Literature}

Alföldi, A., Die Ausgestaltung des monarchischen Zeremoniells am römischen Kaiserbofe. RM XLIX (1934) 1-118.

- - Insignien und Tracht der römischen Kaiser. RM L(1935) 134-139.

Allard, P., Histoire des persécutions pendant les deux premiers siècles. Paris, 1885.

Allo, E. B., Les dieux sauveurs du paganisme gréco-romain. RSPhT XV (1926) 5-24.

- - St. Jean: L'Apocalypse. Paris, 1933.

Altheim, Fr., La religion romaine antique. Paris, 1955.

Balley, C., Phases in the Religion of Ancient Rome (Sather Classical Lectures, Vol. 10) California, 1932.

Barclay, W., The Revelation of Jobn. Edinburgh, 1959.

Bate, H. N., The Sibylline Oracles (Bks. III-V) London, 1918.

Baudissin, W. W. von, Kyrios als Gottesname im Judentum und seine Stelle in der Religionsgeschichte. 4 vols. Gießen, 1926.

Benort, P., Exégèse et Théologie, Paris 1961.

Beurlier, E., Le culte impérial: son bistoire et son organisation depuis Auguste jusqu'à Justinien. Paris, 1891.

Bevan, E., Histoire des Lagides. Paris, 1934.

BI(c)kerman(N), E., Die römische Kaiserapotheose. ARW XXVII (1929) pp. 1-34.

- - Institutions des Séleucides. Paris, 1938.

Blumenthal, F., Der ägyptische Kaiserkult. APF V (1913) pp. 317-345.

Boemling, H., Zum Begriff Kyrios bei Paulus. ZNTW XIV (1913) 23-37.

Bömer, F., Tityrus und sein Gott. WJA IV (1949-50) pp. 60-70.

Boismard, M. E., L'Apocalypse. Paris, 1950.

Borssier, G., La religion romaine d'Auguste aux Antonins. Paris, 1874.

- - L'opposition sous les Césars. Paris, $1902^{2}$.

Born, L. K., The Perfect Prince According to the Latin Panegyrists. AJPh LV (1934) pp. 20-35.

Bousset, W., Der Gebrauch des Kyriostitels als Kriterium für die Quellenscheidung in der ersten Hälfte der Apostelgeschichte. ZNTW XV (1914) 141-162.

BrÉHIER, L. \& BATIFFol, P., Les survivances du culte impérial romain. Paris, 1920.

Brun, L., Die römischen Kaiser in der Apokalypse. XXVI ZNTW (1927) 128-151.

Buckler, W. H., Auguste, Zeus Patroos (Sur l'origine du culte rendu aux Césars). $\mathrm{RPh}$ IX (1935) 3e sér. 177-188. 
Bultmann, R., Theology of the New Testament. London, 1965.

Camelot, Th., Martyre de Polycarpe. Sources chrétiennes. Paris, 19694.

Canfield, L. H., The Early Persecutions of the Christians. (Studies in History, Economics and Public Law. Vol. LV, no. 2). New York, 1913.

Cerfaux, L., Le titre Kyrios, dans Recueil Lucien Cerfaux, Gembloux 1954, I, pp. 3-188.

Cerfaux, L. \& Tondriau, J., Le culte des souverains. Tournai, 1956.

Charles-Picard, G., Les trophées romains. Paris, 1957.

- - Auguste et Néron. Le secret de l'empire. Paris, 1962.

Charlesworth, M.P., Some Observations on the Ruler Cult, Especially in Rome. HThR XXVIII (1935) 1 pp. 5-44.

- - Providentia and Aeternitas. HThR XXIX (1936) 2 pp. 107-132.

Cochrane, C. N., Christianity and Classical Culture. Oxford, 1944. Reprint: New York, 1957.

Cullmann, O., The State in the New Testament. New York, 1956.

- - The Christology of the New Testament. London, 1963.

Cumont, Fr., Un serment de fidélité à l'empereur Auguste. REG XIV (1901) 26-45.

- - Astrology and Religion among the Greeks and Romans. London, 1912.

- - Etudes syriennes. (L'aigle funéraire d'Hiérapolis et l'apothéose des Empereurs.) Paris, 1917.

- - Les religions orientales dans le paganisme romain. Paris, 19294.

- - Recherches sur le symbolisme funéraire des Romains. Paris, 1942.

- - Lux Perpetua, Paris 1949.

Deissmann, A., Light from the Ancient East (Licht vom Osten) trans. by L. R. R. Strachan. London, 1927.

Deonna, W., La légende d'Octave-Auguste, dieu, sauveur et maître du monde. RHR LXXXIII (1921) 32-58.

Dessau, H., Geschichte der römischen Kaiserzeit. Berlin, 1924-30. 2 vols.

Dibelius, M., Rom und die Christen im ersten Jabrbundert (Sitzungsberichte der Heidelberger Akademie der Wissenschaften. Phil. Hist. Klasse. Jahrg. 194142. Abh. 2.) Heidelberg, 1942.

Dieckmann, H., Die Auferstehungsberichte der vier Evangelien nach ibrer Verschiedenbeit und Eigenart. Scholastik II (1928) 321-340.

Dовеsch, G., Caesars Apotheose zu Lebzeiten und sein Ringen um den Königstitel. Vienna, 1966.

Doвschưtz, E. von, Kúpıos 'Inбoũs. ZNTW XXX (1931) 97-123.

Dodd, C. H., The Epistle of Paul to the Romans. London, 1932 (Fontana Books. 4th impression, 1965)

- - The Bible and the Greeks. London, 1935.

- - According to the Scriptures. London, 1952.

Duchesne, L., Le Concile d'Elvire et les Flamines chrétiens. Mélanges Renier, pp. 159-174. Paris, 1887.

Durrwell, F. X., The Resurrection. London / Melbourne, 1960.

Eitrem, S., Zur Apotheose. VI. Kaiserbilder. SO XV (1936) 111-137. 
Etienne, R., Le culte impérial dans la péninsule ibérique d'Auguste à Dioclétien (Bibliothèque des Ecoles françaises d'Athènes et de Rome. Fasc. 191) Paris, 1958.

FARNELL, L. R., Greek Hero-Cults and Ideas of Immortality. Oxford, 1921.

FARrer, A. M., The Revelation of St. Jobn the Divine. Oxford, 1964.

Festugtère, A. J., L'idéal religieux des Grecs et l'Evangile. Paris, 1932.

Filson, F. V., The New Testament against its Environment. London, 1950.

- - A New Testament History. London, 1965.

Fincke, A., De appellationibus Caesarum bonorificis et adulatoriis usque ad Hadriani aetatem apud scriptores Romanos obviis. Regimonti, 1867.

Foerster, W. \& Quell, G., Lord. London, 1958.

French, S. H., An Exposition of the Book of Revelation. London, 1968.

Fuller, R. H., The Foundations of New Testament Christology. London, 1965.

GAGÉ, J., La Victoria Augusti et les auspices de Tibère. RA XXXII (1930) 1-35.

- - Romulus-Augustus. MEFR XLVII (1930) 138-181.

- - Les sacerdoces d'Auguste et ses réformes religieuses. MEFR XLVIII (1931) $75 \mathrm{ff}$.

- - Divus Augustus. RA XXXIV (1931) 11-41.

- - Un thème de l'art impérial romain. La Victoire d'Auguste. MEFR XLIX (1932) 61-92.

- - La théologie de la Victoire impériale. RH CLXXI (1933) 1-43.

Glasson, T. F., The Revelation of John. Cambridge, 1965.

Goppelt, L., Christentum und Judentum im ersten und zweiten Jabrbundert. Gütersloh, 1954.

Grant, F. C., Roman Hellenism and the Neev Testament. Edinburgh and London, 1962.

Grant, M., From Imperium to Auctoritas. Cambridge, 1946.

Grant, R. M., A Historical Introduction to the New Testament. New York, 1963.

Green, W. M., Notes on the Augustan Deities. CLJ Nov. XXIII (1927) 86-93.

GrÉgoIre, H., Les persécutions dans l'empire romain. Mémoires de l'Académie royale, XLVI. 1. Bruxelles, 19642.

Gsell, S., Essai sur le règne de Domitien. Paris, 1894.

- - Les statues du temple de Mars Ultor à Rome. RA XXXIV (1899) 37-43.

Guterman, S. L., Religious Tolerance and Persecution in Ancient Rome. London, 1951.

Haвicht, C., Gottmenschentum und griechische Städte. München, 1956.

Haerens, H., $\Sigma \omega \tau \eta^{\prime} \rho$ et $\Sigma \omega \tau \eta \eta \dot{\alpha} \alpha$. Stud. Hell. V (1948) 57-68.

HaHn, Fr., The Titles of Jesus in Christology. London, 1969.

Haight, E. H., An 'Inspired Message' in the Augustan Poets. AJPh XXXIX (1918) 341-366.

Halliday, W. R., The Pagan Background of Early Cbristianity. Liverpool \& London, 1925.

Hatт, J. J., Histoire de la Gaule romaine. Paris, $1966{ }^{2}$.

Hefele, C. J., Histoire des conciles d'après les documents originaux, Paris, tome I, 1907.

HeINEN, H., Zur Begründung des römischen Kaiserkultes. "Chronologische Übersicht von 48 v. bis 14 n. Cbr. Klio XI (1911) pp. 129-177. 
Hoffman Lewis, M. W., The Official Priests of Rome under the Julio-Claudians. MAAR Papers and Monographs XVI (1955).

Hülsen, C., The Burning of Rome under Nero. AJA XIII (1909) 45-48.

IDRIs-Bell, H., Cults and Creeds in Graeco-Roman Egypt. Liverpool, 1954.

IмміsсH, O., Zum antiken Herrscherkult: (Aus Roms Zeitwende): Das Erbe der Alten. 2. Reihe, 20, Leipzig, 1931, pp. 1-36.

Jacquier, E., Les Actes des Apôtres. Paris, 1926.

Jeanmaire, H., Le messianisme de Virgile. Paris, 1930.

Kampers, F., Die Geburtsurkunde der abendländischen Kaiseridee. HJ XXXVI (1915) 233-270.

Kennedy, H. A. A., Apostolic Preacbing and Emperor Worship. The Expositor. April (1909) 289-307.

- - St. Paul and the Mystery-Religions. London, 1913.

Kiddle, M., The Revelation of St. John. London, 1940.

Kittel, G., Theological Dictionary of the New Testament (Theologisches Wörterbuch zum Neuen Testament, trans. G. W. Bromiley). Michigan, 1967.

Klauser, T., Reallexikon für Antike und Christentum. Stuttgart, $1950 \mathrm{ff}$.

Koenler, L., Christus im Alten und im Neuen Testament. ThZ IX (1953) 241-259.

Kornemann, E., Zur Geschichte der antiken Kaiserkulte. Klio I (1901) 51-146.

Kraus, Th., Das römische Weltreich. Berlin, 1967.

LAST, H., The Study of the Persecutions. JRS XXVII (1937) 80-92.

Lattimore, R., Portents and Prophecies in Connection with the Emperor Vespasian. CLJ XXIX (1934) 441-449.

Lepper, F. A., Some Reflections on the Quinquennium Neronis. JRS XLVII (1957) 95-103.

Linssen, H., Theos Soter. Diss. Bonn, 1929. JLW VIII (1928) 1-75.

Loesch, S., Deitas Jesu und antike Apotheose. Rottenburg. 1933.

Loewe, H., Render unto Caesar. Cambridge, 1940.

LoHse, E., Die Offenbarung des Jobannes. Göttingen, 1960.

Marsh, F. B., The Reign of Tiberius. London, 1931.

Maranon, G., Tiberius. London, 1956.

Magre, D., Roman Rule in Asia Minor to the End of the Third Century after Christ. 2 vols. Princeton, 1950.

Macmullen, R., Enemies of the Roman Ordier. Cambridge, Mass. and London, 1967.

Mattingly, H., Christianity in the Roman Empire. Otago, 1955.

Millar, F. G. B., A Study of Cassius Dio. Oxford, 1964.

Mohrmann, C., Epiphania. RSPhT XXXVII (1953) 644-670.

Moreau, J., La persécution du christianisme dans l'empire romain. Paris, 1956.

Morrison, C. D., The Pouvers that Be. London, 1960.

Moule, C. F. D., The Birth of the New Testament. New York, 1963.

Moulton, J. H. \& Milligan, G., The Vocabulary of the Greek Testament. London, 1930.

Nilsson, M. P., The Dionysiac Mysteries of the Hellenistic and Roman Age. Lund, 1957.

Nock, A. D., Notes on the Ruler-Cult. JHS XLVIII (1928) 21-43. 
Nolan, B.M., The Parousia and New Testament Theology. Irish Theological Quarterly XXXVI (1969) 283-314.

Nordstroem, C. O., Ravennastudien. Figura 4. Stockholm, 1953.

Owen, E. C. E., Some Authentic Acts of the Early Martyrs. Oxford, 1927, London, 1933.

Perler, O., Die Mosaiken der Juliergruft im Vatikan. Freiburg i. Ue. 1953.

- Die Darstellung der Eucharistie auf dem Theodor-Mosaik in Aquileia. Rivista di Archeologia Christiana. (Roma) XLIII (1967) 233-249.

Peterson, E., Els @eós. Göttingen, 1926.

- - Göttliche Monarchie. ThQ CXII (1931) 537-564.

- - Zeuge der Wabrbeit. Leipzig, 1937.

Pippidr, D. M., Le 'Numen Augusti'. REL IX (1931) 83-111.

- - La date de l'Ara Numinis Augusti de Rome. REL XI (1933) 453-456.

Pleket, H. W., An Aspect of the Emperor Cult: Imperial Mysteries. HThR LVIII (1965) 331-347.

Preston, R. H. \& Hanson, A. T., The Revelation of St. Jobn the Divine. London, 1949.

Prümm, K., Herrscberkult und Neues Testament. Biblica, IX (1928) 3-25; 129-142; 289-301.

- - Religionsgeschichtliches Handbuch fïr den Raum der altchristlichen Umwelt. Rome, 1954.

ReID, J. S., Roman Ideas of Deity. JRS VI (1916) 171-184.

RIEwald, P., De Imperatorum Romanorum cum certis dis et comparatione et aequatione. Diss. Phil. Hal. 20. 3 (1912) 265-344.

Rigaux, B., L'antéchrist et l'opposition messianique dans l'Ancien et le Nouveau Testament. Paris, 1932.

Rissr, M., Zeit und Geschichte in der Offenbarung des Jobannes. Basel, 1952.

Roes, A., L'aigle psychopompe de l'époque impériale. Mélanges Charles Picard II 1949. 881-891.

- - L'aigle du culte solaire syrien. RA XXXVI (1950) 129-146.

Roнde, E., Gottesglaube und Kyriosglaube bei Paulus. ZNTW (1933) 43-57

Rose, H. J., Roman Religion. JRS L (1960) 161-172.

Rostovtzeff, M., L'empereur Tibère et le culte impérial. RH CLXIII (1930) 1-26.

Rouffiac, J., Recherches sur les caractères du grec dans le Nouveau Testament d'après les inscriptions de Priène. Paris, 1911.

Sabourin, L., Les noms et les titres de Jésus. Paris, 1963.

Sanders, J. N., Christianity and Paganism - Some Reflections on the History of the Roman Empire. Cam. J. I (1948) 292-304.

Sattler, P., Augustus und der Senat. Göttingen, 1960.

SAuter, F., Der römische Kaiserkult bei Martial und Statius. Stuttgart / Berlin, 1934.

Schnabel, P., Zur Frage der Selbstvergötterung Alexanders. Klio XX (1926) 398-414.

Schonfield, H. J., Saints against Caesar. London, 1948.

Scotr, K., Identification of Augustus with Romulus. TAPhA LVI (1925) 82-105.

- - Plutarch and the Ruler Cult. TAPhA LX (1929) 117-135.

- - Emperor Worship in Ovid. TAPhA LXI (1930) 43-69. 
Scotr, K., The Significance of Statues in Precious Metals in Emperor Worship. TAPhA LXII (1931) 101-123.

- - Humor at the Expense of the Ruler Cult. CLPh XXVII (1932) 317-328.

- - The Elder and Younger Pliny on Emperor Worship. TAPhA LXIII (1932) 156165.

- - The Imperial Cult under the Flavians. Stuttgart, 1936.

Selwyn, E. G., The Persecutions in I Peter. SNTS Bulletin I (1950) $47 \mathrm{ff}$.

SpicQ, C., Agapé dans le Nouveau Testament. 3 vols. Paris, 1959.

- - Les Epîtres Pastorales. Paris, 19694.

Starr, C. G., Civilization and the Caesars. New York, 1954.

Stauffer, E., Christ and the Caesars. London, 1955.

TAEger, F., Charisma. Studien zur Geschichte des antiken Herrscherkults. II Stuttgart, 1960.

TAYLOR, L. R., Livy and the Name Augustus. CR XXXII (1918) 158-161.

- - The Worship of Augustus in Italy during bis Lifetime. TAPhA LI (1920) 116-136.

- - The 'Proskynesis' and the Hellenistic Ruler Cult. JHS XLVII (1927) 53-62.

- - Tiberius' Refusals of Divine Honours. TAPhA LX (1929) 87-101.

- - The Divinity of the Roman Emperor. Middletown, Conn. 1931.

TAYLOR, V., The Names of Jesus. London, 1953.

Thieme, G., Die Inschriften von Magnesia am Mäander und das Neue Testament. Göttingen, 1906.

TONDRIAU, J., Le point culminant du culte des souverains. LEC XV (1947) 100-113.

- - Romains de la république assimilés à des divinités. SO XXXVII (1949) 128-140.

Touilleux, P., L'Apocalypse et les cultes de Domitien et de Cybèle. Paris, 1935.

Trench, R. C., Synonyms of the New Testament. London, 1871.

WAGNER, W., U'ber ' $\Sigma \Omega Z E I N '$ und seine Derivata im Neuen Testament. ZNTW VI (1905) 205-235.

Ward, M., The Associations of Augustus with Jupiter. SMSR IX (1933) 213-218.

WeNDlaND, P., ' $\Sigma \Omega T H P '$. ZNTW V (1904) 335-353.

Wetter, G. P., Der Sobn Gottes. Göttingen, 1916.

White, A. N. Sherwin, Racial Prejudice in Imperial Rome. Cambridge, 1967.

- - Roman Society and Roman Law in the New Testament. Oxford, 1963.

Wilamowitz-Moellendorff, U. von \& Zucker, F., Zwei Edikte des Germanicus auf einem Papyrus des Berliner Museums. SbB XXXIII (1911) 794-821.

Windisch, H., Das Neue Testament im Lichte der neu gefundenen Inschriften, Papyri und Ostraka. NJbb (1910) 201-222.

Wissowa, G., Religion und Kultus der Römer. Munich, $1912^{2}$.

ZeILler, J., L'Empire romain et l'Eglise. Paris, 1928. 


\section{ABBREVIATIONS}

ABSA Annual of the British School in Athens (London).

AHR American Historical Review (New York).

AJA American Journal of Archaeology (Princeton).

$\mathrm{AJPh}$ American Journal of Philology (Baltimore).

APF Archiv für Papyrusforschung und verwandte Gebiete (Leipzig).

ARW Archiv für Religionswissenschaft (Freiburg i. Br., Tübingen).

BJ Bonner Jahrbücher des Rhein. Landesmuseums in Bonn und des Vereins von Altertumsfreunden im Rheinlande.

BMC H. Mattingly, Coins of the Roman Empire in the British Museum.

$\mathrm{CAH}$ Cambridge Ancient History. Cambridge, 1923-39.

Cam. J Cambridge Journal.

CIL Corpus Inscriptionum Latinarum. Leipzig/Berlin, $1862 \mathrm{ff}$.

CLJ Classical Journal (Ohio).

CLPh Classical Philology (Chicago).

CLR Classical Review (Oxford).

ET Expository Times.

HE Eusebius, Church History.

HJ Historisches Jahrbuch (Köln).

HThR Harvard Theological Review (Cambridge, Mass.).

JBM Jahrbuch des Bernischen Historischen Museums (Bern).

JdI Jahrbuch des Deutschen Archäologischen Instituts (Berlin).

JLW Jahrbuch für Liturgiewissenschaft (Münster).

JHS Journal of Hellenic Studies (London).

JRS Journal of Roman Studies (London).

LCL Loeb Classical Library. London \& Cambridge / Mass.

LEC Les Etudes Classiques (Namur).

MAAR Memoirs of the American Academy in Rome.

MEFR Mélanges d'Archéologie et d'Histoire de l'Ecole Française de Rome (Paris).

NJbb Neue Jahrbücher für antike und deutsche Bildung (Leipzig).

OGIS Orientis Graeci Inscriptiones Selectae, ed. W. Dittenberger. 2 vols. Leipzig, 1903-05.

Ox. Pap. The Oxyrhynchus Papyri, ed. B. Grenfell \& A. Hunt, 1898 ff.

PBA The Proceedings of the British Academy (Oxford).

PL J. Migne, Patrologiae cursus completus. Series Latina (Paris, $1845 \mathrm{ff}$.). 


\begin{tabular}{|c|c|}
\hline RA & vue archéologique (Paris). \\
\hline RBl & Revue Biblique (Paris). \\
\hline $\mathrm{RE}$ & $\begin{array}{l}\text { Paulys Real-Encyclopädie der classischen Altertumswissenschaft } \\
\text { (Stuttgart). }\end{array}$ \\
\hline REG & Revue des Etudes grecques (Paris). \\
\hline REL & Revue des Etudes Latines (Paris). \\
\hline RH & Revue Historique (Paris). \\
\hline RHPR & Revue d'Histoire et de Philosophie religieuse (Paris). \\
\hline RHR & Revue d'Histoire des Religions (Paris). \\
\hline RM & $\begin{array}{l}\text { Mitteilungen des deutschen archäologischen Instituts. Römische Ab- } \\
\text { teilung (Rome). }\end{array}$ \\
\hline $\mathrm{RPh}$ & Revue de Philologie, de Littérature et d'Histoire ancienne (Paris). \\
\hline RSPhT & Revue des Sciences Philosophiques et Théologiques (Paris). \\
\hline $\mathrm{SbB}$ & $\begin{array}{l}\text { Sitzungsberichte der preußischen Akademie der Wissenschaften } \\
\text { (Berlin). }\end{array}$ \\
\hline SMSR & Studi e Materiali di Storia delle Religioni (Rome). \\
\hline SNTS & Studiorum Novi Testamenti Societas. \\
\hline SO & Symbolae Osloenses (Oslo). \\
\hline Syll. & $\begin{array}{l}\text { Sylloge Inscriptionum Graecarum, ed. W. Dittenberger, vol. I-IV, } \\
\text { Leipzig, ed. 3, 1915-1924. }\end{array}$ \\
\hline TAPhA & $\begin{array}{l}\text { Transactions and Proceedings of the American Philological Asso- } \\
\text { ciation (Cleveland, Ohio). }\end{array}$ \\
\hline ThDNT & Kittel, Theological Dictionary of the New Testament. Michigan, 1965. \\
\hline ThQ & Theologische Quartalschrift (Tübingen). \\
\hline ThWNT & $\begin{array}{l}\text { Kittel, Theologisches Wörterbuch zum Neuen Testament. Stuttgart, } \\
1933 \text { ff. }\end{array}$ \\
\hline ThZ & Theologische Zeitschrift (Basel). \\
\hline TTZ & Trierer theologische \\
\hline WJA & Würzburger Jahrbücher für die Altertumswissenschaft (Würzburg). \\
\hline YCLSt & Yale Classical Studies (New Haven, Conn.). \\
\hline ZNTW & $\begin{array}{l}\text { Zeitschrift für die neutestamentliche Wissenschaft und die Kunde } \\
\text { der älteren Kirche (Berlin). }\end{array}$ \\
\hline ZRG & $\begin{array}{l}\text { Zeitschrift der Savigny-Stiftung für Rechtsgeschichte. Romanistische } \\
\text { Abteilung (Weimar). }\end{array}$ \\
\hline
\end{tabular}




\section{INTRODUCTION}

In this work, I have confined myself to certain aspects of imperial cult-worship which are mentioned or implied in the New Testament. Necessarily this does not give an overall view of the imperial cult in the first century, but, since such a study presupposes a knowledge of the general situation in this sphere, the sources and early development of the cult will be discussed briefly in the first part of this work. The mass of material - particularly inscriptions and papyrus texts is so vast that complete lists have not been included, although reference to where they may be found has been made in the footnotes.

In the way of general background and introduction to this work, a brief survey of the development of imperial honours in the Hellenistic East has been included, and I am particularly indebted to Miss L. R. Taylor's book, The Divinity of the Roman Emperor, in this section which is no more than a review of the situation and a study of some of the sources of the imperial cult. The writings of L. Cerfaux and J. Tondriau, in particular, their joint book Le Culte des Souverains, give general outlines of many of the points which have been considered in this work. It is perhaps too facile to see Christian aspects of cult as the direct descendants of Hellenistic worship, but at the same time, one has often to admit the possibility of Hellenistic influences, even if indirectly and in a negative way.

In exegetical works, especially those dealing with the Apocalypse, reference is made to various aspects of cult-worship and terms are used in the New Testament which imply a knowledge or an influence of imperial cult-practices. In this work, I have attempted to study in more detail some of these references, and to add to the interpretations which have already been suggested by the various New Testament commentators, besides giving the historical context and the pagan usage of cult-terms and expressions. In particular, E. B. Allo's work, L'Apocalypse, has constantly been consulted, as it is still one of the 
fundamental works of criticism of the Apocalypse. The twelfth, thirteenth and seventeenth chapters have received the most consideration, for the veiled references to the activities of the two beasts are interpreted as aspects of cult worship.

In dealing with these two 'beasts' of the Apocalypse, there is much that I have deliberately avoided repeating; for example, the question of the 'number of the beast' and the identification of 'the seven heads'. For these points, no attempt has been made to re-assess the problems involved, since this would have been outside the scope of this work.

The chapter concerning the 'blasphemous titles' of the first beast deals with the implications behind the most obvious titles common both to Christ and the emperor, and in addition, I have suggested that the increasing use of acclamations, especially those savouring of the divine, could have scandalized the Christians of the first century and thus occasioned the remarks made in the Apocalypse. The symbol of the beast as described in the seventeenth chapter of the Apocalypse has given rise to speculation as to whether John's words could have been influenced by the legend of Nero Redivivus. A section has been devoted mainly to the accounts of this legend as found in the early texts, and the reasons why such legends could have evolved about this particular emperor.

The most likely interpretation of the mysterious 'second beast' is that it was the symbol of those men who furthered in any way the imperial cult, and this would refer particularly to the imperial priesthood and the pagan priesthoods insofar as they were tools for imperial propaganda and cult-worship. The mention of the image of the beast' gives rise to speculation as to the importance of cult-images in imperial worship and how they were regarded by adherents of the imperial cult or by so-called atheists.

Having given the historical context of such apocalyptic phrases, the significance of two expressions which are striking in the New Testament has been considered, those of Ascension and Epiphany. Both had a considerable influence in fashioning imperial propaganda for the masses, and they had their roots in older civilizations as well. The symbols for the ascension of a ruler were varied and popular in art in all its forms, and reverses of coins especially illustrate the variety of representations in this field.

Persecutions have been dealt with over the years in such detail that it would seem superfluous to add a chapter on this point. Yet 
some mention must be made in order to judge how far the author of the Apocalypse had been influenced by his knowledge of past atrocities committed against the Christians. This, like the first chapter, is a necessary repetition to understand more clearly the background in which the New Testament writers and, in particular, the author of the Apocalypse, were living. 



\section{THE SOURCES OF THE IMPERIAL CULT AND ITS EARLY DEVELOPMENT}

There are very real difficulties in assessing the implications behind the deification of a Roman emperor due in great part to the sophistication of modern thinking, which tends to make a clear, even exaggerated distinction between man and the divine. Christian beliefs have, no doubt, done much to influence this trend away from primitive ideas of divinity and there is little likelihood today that one would accept the possibility of a man passing from the human state to the divine as a result of his heroic actions.

Yet the legends from the most primitive races make us aware of the extent of this belief in the ancient world; heroes evolved into divine beings as a reward for their deeds of great courage during their lifetime. Pliny the Elder acknowledges this fact when he proclaims that to enrol such men - that is, rulers - among the deities, is the most ancient method of showing gratitude for their benefactions ${ }^{1}$. In this manner the heroes received those honours which were normally reserved for the gods; in Greece, for example, prayers and libations were offered to former heroes before an important event, and an illustration of this is given by Plutarch when he relates how Alexander made a sacrifice to Athena at Ilium and poured out libations to the heroes to obtain favour for his expedition against Persia ${ }^{2}$.

While considering the parallels to the symbolism of the emperorcult in the New Testament, it is necessary to understand the effect such a cult would have had on the minds of the Romans of this epoch, and the traditions and conceptions which, over the centuries,

1 Pliny, Natural History II 19: «hic est vetustissimus referendi bene merentibus gratiam mos, ut tales numinibus adscribant."

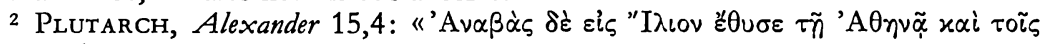

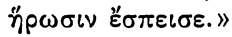


had stimulated this particular form of worship. To grasp fully the position of the first Roman emperor, it is necessary to trace back these traditions to the real predecessor of Augustus, Alexander, who conquered for himself an immense empire, embracing as it did those Oriental kingdoms which had previously known periods of great glory and a developed culture - Persia, Babylon and Assyria.

\section{a) Divine Honours in the Hellenistic East}

In the Greek world, divine honours had been bestowed by many cities on their founder or ruler after his death, and he came to be regarded as the patron and protector of the city, to whom it was expedient that the inhabitants should offer their prayers. Internal crises led cities to go even farther, in rendering divine honours to their deliverers or 'Saviours', even during their lifetime ${ }^{1}$. We learn from Plutarch that Lysander was the first Greek to receive such honours during his lifetime, with altars, offerings and paeans, the songs of triumph ${ }^{2}$. The same author also recounts how the Samians decided to change the name of their festival formerly dedicated to Hera, and to give it the new title of Lysandreia, in honour of Lysander ${ }^{3}$.

The cross-currents of Oriental influences in the Greek world makes it possible to understand how the demand of Alexander, that he should be regarded as a god, came to be accepted as reasonable, for the achievements of Alexander seemed to be those of a super-man and had never been equalled in the past. By the end of the fourth century B. C., few Greeks would have regarded deification or even the rendering of divine honours as an impious act worthy of blame.

Divine honours were not always imposed from above, however, and even in the case of Alexander, it is probable that the honours resulted in some measure from the spontaneous enthusiasm of the people. Yet it was Alexander himself who made the demand for

1 As M. P. Charlesworth points out (Some Observations on the Ruler Cult, Especially in Rome. HThR XXVIII (1935), p. 11), these honours would have been given to their saviour "had he died in the moment of achievement.»

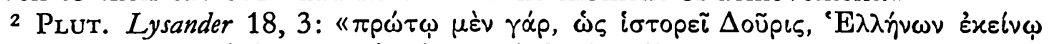

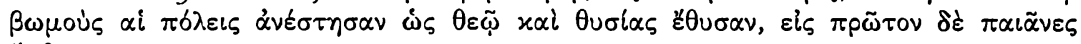
$\ddot{\eta} \sigma \theta \eta \sigma \alpha \nu \ldots .$.

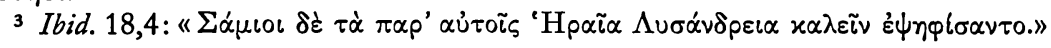


divine worship ${ }^{1}$, and who encouraged the belief that he was Dionysus incarnate. This cult of Alexander was the corner-stone of the developing ruler-cult and formed the basis for the imperial cult which was to play such an important role in the political and religious life of the Empire ${ }^{2}$.

The Orientals were accustomed to giving divine honours, not only to their heroes, but also to their kings, for whom deification was a key factor in the upholding of their position. In Egypt, for example, it had been the practice to look on the Pharaoh as «the great and good god», transformed by the act of coronation into «the Son of the Sun".

The Ptolemies continued the tradition of the Pharaohs, organizing the cult of all the princes who had reigned in Egypt since the time of Alexander. The apotheosis of the living ruler, however, did not hold a deep significance for the Greeks in Egypt at this epoch. Thus the Hellenistic rulers followed the precedent started by Alexander of forming State cults in their kingdom. The inscriptions and coins of this period testify to a flourishing cult, for such titles as 'Soter' and 'Theos' are very common at this time ${ }^{3}$. Having formed a cult to Alexander at Alexandria by about 285/4 B. C., Ptolemy I gave a new look to cult worship in Egypt, and after his death, Ptolemy II formed a combined cult of the deceased ruler and Berenice under the title of ' $\theta \varepsilon \circ i \Sigma \omega \tau \eta \tilde{p} \varepsilon \varsigma^{\prime}$ and later a festival known as Ptolemaieia was founded in their honour. Ptolemy II and Arsinoë shared a cult during their lifetime with the deceased rulers.

The cult-forms rendered to rulers in Egypt fall into two main divisions; that going back to Ancient Egypt and the official state cult with its Greek form and origin ${ }^{4}$. This division is perhaps too 28.

1 L. R. TAYLOR, The Divinity of the Roman Emperor, Middletown, 1931, pp. 21-

2 For more details of the cult to Alexander, cf. P. Schnabel, Zur Frage der Selbstvergötterung Alexanders. Klio XX (1926) pp. 398-414. - U. WILCKEN, Alexanders $Z$ ug in die Oase Siwa. SbB XXX (1928) pp. 576-603. In particular, pp. 588590: Die Gewinnung der Gottessohnschaft als Motiv. - W. W. TARN, The Hellenistic Ruler-Cult and the Daemon, JHS XLVIII (1928) pp. 206-219. - A. D. Nock, Notes on the Ruler-Cult, JHS XLVIII (1928) pp. 21-30. - L.R. FarNeLL, Hellenistic Ruler-Cult, JHS XLIX (1929) pp. 79-81. - K. PRÜмM, Der christliche Glaube und die altheidnische Welt, I. Leipzig, 1935, pp. 180-182. - C. НАвICHт, Gottmenschentum und griechische Städte, Munich, 1956, pp. 17-36.

3 E. Bikerman, Les Institutions des Séleucides, Paris, 1938, Ch. VII.

4 This distinction is made by TaYlor, Divinity, p. 30; cf. also, E. Bevan, Histoire des Lagides, Paris, 1934, pp. 66-67. 
superficial once the inscriptions are studied more closely - the private cult offered by the Greeks according to their own customs, and the application to the ruler of such divine titles as were fitting, had no connection with the cult offered by the Egyptians in their temples, and attested by the language of the priestly decrees such as is found on the famous Rosetta Stone. There is also evidence for cult-worship offered by cities in particular for their special patron, such as that of Alexander in Alexandria, not to be confused with the official cult of Alexander which was established by the government for the whole country.

The Seleucids received divine honours in many towns and were officially deified after their death. Seleucos I was honoured as

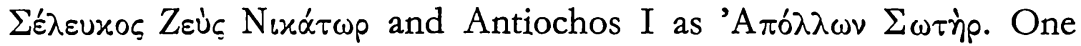
searches in vain for uniformity of cult in the vast Empire of the Seleucids but the various Oriental influences which exercised a certain pressure in the development of cult-forms, seem to have led to certain deviations from the Greek form of worship ${ }^{1}$.

Besides the conferring of such titles as 'God' or 'Saviour' on the ruler, titles which at once point to a flourishing cult, other honours were offered to the Seleucids, parallels of which we find repeated in the early Roman Empire. A month was occasionally renamed in honour of the ruler, and already in 281 B. C., Ilium had a month called 'Seleuceios' 2. Towns were likewise renamed in honour of certain rulers, as is seen with Seleucia in Pieria and Antioch in Syria. This custom continued during the Empire; for example, Tiridates rebuilt Artaxata and renamed it Neronia in 66 A. D. ${ }^{3}$. We find similar examples for this practice during the reign of Augustus; soon after 25 B. C., Juba II of Mauretania began the construction of his residence of Iol, which he called Caesarea in honour of Augustus sometime after this year ${ }^{4}$. In 22 B. C., Herod began the construction kiden.

1 Cf. Навіснт, Gottmenschentum, pp. 105-108: Gründerkulte der ersten Seleu-

2 Bikerman, Institutions, p. 246, note 3. - An interesting point has been noted by D. Magie, Roman Rule in Asia Minor to the End of the Third Century after Christ, Princeton, 1950, p. 490. The Samians introduced a new system of dating years based on the 'years of apotheosis' of Augustus. IGR IV 1726, 1732.

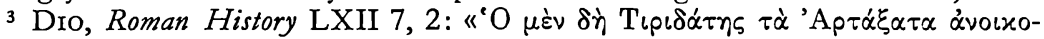

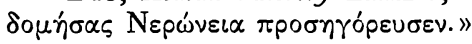

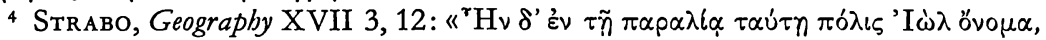

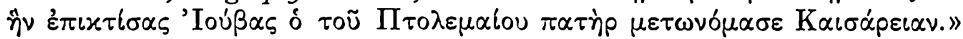


of another town which he called Caesarea in honour of Augustus, although official dedication did not take place until 9 B.C. Describing Judaea, Strabo mentions how Herod re-named Samaria Sebaste, that is, in Latin, Augusta, in honour of Augustus ${ }^{1}$. In Cilicia, there is evidence that Anazarbus received the name of Caesarea from Augustus, and some years later, the emperor allowed the inhabitants of Paphos to call their newly erected town, Augusta.

There is another interesting parallel between the cult paid to the Hellenistic rulers and that of Augustus; in Pergamum, the ruler was only deified at his death, and only at this point did he receive the title of 'theos', although later coins bear the portrait of an eponymous priest of the reigning ruler.

During the Hellenistic period, the ruler replaced the democratic policy of the Classical period, and it was for this reason that men looked towards the ruler for all their temporal needs. He was their protector, the providence of the gods on earth and he became the object of their prayers and sacrifices that he might safeguard their livelihoods and even their lives.

\section{b) Divine Honours in the Roman Republic}

Thus it may be appreciated how general the notion of deification for rulers and heroes was in the East, and it was freely accepted that honours should be paid to such persons. It was from the East that the cult rendered to the sovereigns and their representatives passed to the West. Contact with the East was the link which made the idea of worship of a man acceptable to the Roman mind; the Greek attitude was particularly prone towards deification after periods of tension, and in particular, the deliverance from a foreign aggressor. Roman governors who gave the impression of justice were looked on as liberators from oppressors, and Tacitus tells of Smyrna's declaration that she had erected a temple to Rome as early as $195 \mathrm{~B}$. C., in the consulship of Marcus Porcius ${ }^{2}$.

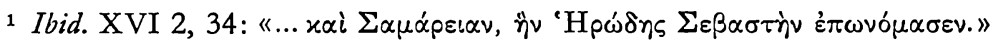

2 Tacirus, Annales IV 56 (ed. C. D. Fisher. Oxford, 1953): «seque primos templum urbis Romae statuisse, M. Porcio consule.» In his book Christianity and Classical Culture, New York, 1953, p. 25, C. N. Cochrane writes that in order to understand the meaning of the emperor-cult, it is necessary to look into the «mental processes which led to its formation». Its expression was «the veneration 
The liberation of Greece by Rome's representative, Titus Quinctius Flamininus, earned for him the general adulation of the people of Greece - altars were erected in his name, hymns of praise were sung in his honour, and sacrifices were offered which continued, Plutarch points out, "even down to our own day" ${ }^{1}$. Inscriptions show that his name was linked with those of the gods, and dedications were

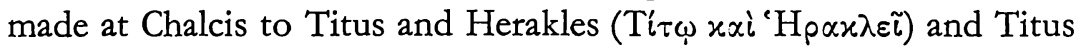

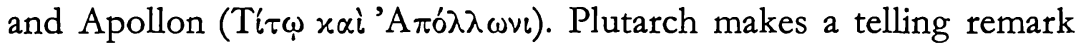
concerning these and other honours which Titus received from the Greeks: "that these honours were made sincere by the astonishing good-will which his equitable nature called forth" ${ }^{2}$. This phrase suggests an underlying sense - that other honours offered in less favourable circumstances lacked the sincerity and spontaneity which gave them real meaning; a suggestion which gives a clue to the attitude of Roman citizens faced with much the same situation but without the "astonishing good-will» of the people, as, for example, during the latter part of the reign of Domitian.

Roman governors continued to receive such honours from the grateful provincials who recognized the justice and tolerance of the distant power of Rome in the representative who ruled directly over them; the example of Cicero is well-known, how the provincials of Cilicia offered him "statues, shrines and sculptured chariots», which were, nevertheless, refused ${ }^{3}$.

The religious traditions of the Romans differed greatly from those of the Greeks, yet the notion of deification for their ancient kings was not totally absent from the Roman way of thinking, for, according to Virgil, they adored Picus, Faunus and Latinus who were said to have reigned on the Latium, and to whom he gives the title of $« \mathrm{Di}$ patrii, indigetes» ${ }^{4}$. Similarly, there is the legend of Romulus who

of the living and the deification of the dead emperor ". Neither of these two forms were a novelty to Rome. Roman magistrates received veneration like the sovereigns in the Hellenistic world.

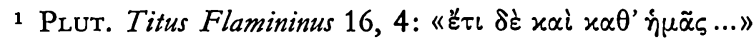

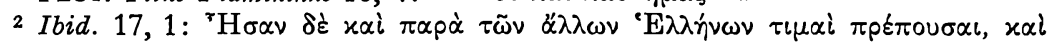

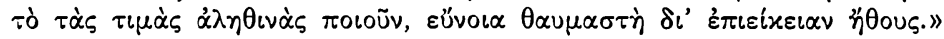

3 Cicero, Ad. Att. V 21,7 (ed. D. R. Shackleton Bailey, Cambridge 1968): "Ob haec beneficia, quibus illi obstupescunt, nullos honores mihi nisi verborum decerni sino; statuas, fana, $\tau \varepsilon \theta \rho \imath \pi \pi \alpha$ prohibeo.»

4 Virgil, Georgics I 498 (Commentary by J. Connington and H. Nettleship) Hildesheim, 1963. 
was caught up into heaven where he became «a benevolent god for them instead of a good king ${ }^{1}$.

The Di Manes were given a general veneration; there seems to have been nothing in early Roman history which compares with the Greek hero-cult, but already towards 150 B. C., foreign ideas and practices had influenced the Roman conception of apotheosis, and even Romans themselves developed little by little this tendency to offer divine honours to their deliverers ${ }^{2}$.

After the murder of the Gracchi, the people attempted to show how much they missed and longed for the brothers, offering them divine honours in a remarkably lavish manner. Statues of the Gracchi were set in a conspicuous place, the very ground where they had been killed was consecrated and the first-fruits of the season were placed before them. In his description of these honours, Plutarch paints a picture of the most extravagant worship, for many went so far as to prostrate themselves and offered their sacrifices before the statues each day, acting in the same way as they did before the shrines of the gods ${ }^{3}$. Plutarch also recounts how, after the defeat of the Teutones and Cimbri, the victory was attributed entirely to Marius, and the people acclaimed him the third founder of Rome, besides which, during their celebrations at home with their families, they brought the ceremonial offerings to Marius as they did to the gods ${ }^{4}$. It is difficult to judge whether these examples are of honours offered to 'divine men', or merely the expression of the gratitude of an enthusiastic and over-demonstrative people; it depends on whether the people made the offerings to the Gracchi or to Marius as if they were gods, or whether the phrase "as they did to the gods" is Plutarch's interpretation of the actions and motives of the people.

Cicero's views on the subject are worth a closer glance, for he himself refused the honours offered him by the provincials of Cilicia, yet showed no indignation at such exceptional honours as statues and incense as were offered to Marius Gratidianus as a mark of gratitude

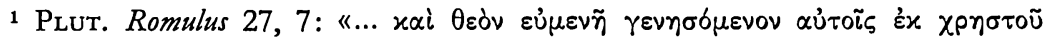
$\beta \alpha \sigma \iota \lambda \dot{c} \omega \varsigma . »$

2 Cf. M. P. Charlesworth, Observations on the Ruler Cult, p. 22.

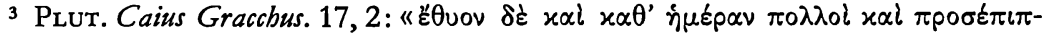

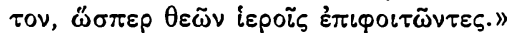

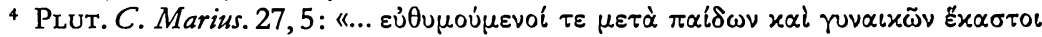

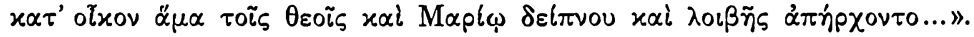


for an edict issued while he was praetor ${ }^{1}$. The Roman belief that deceased parents should be regarded as gods is another point supported by Cicero ${ }^{2}$, and he also stresses that the rites of the family and ancestors should be preserved ${ }^{3}$. The Lares were the souls of the ancestors of each family, who according to Servius, received this honour because they had originally been buried in the home ${ }^{4}$.

Although the imperial cult as such was an Augustan innovation, much was adapted from the earlier Roman traditions, or through contacts with the Hellenistic world, or from more primitive civilizations. Honours offered to deliverers and benefactors were certainly foreign to the Roman mind, yet contact with these notions certainly accustomed the Romans to the Eastern ideas concerning the deification of their great men. Towards the end of the Roman Republic, as later during the Augustan age, poetic licence allowed the title of 'deus' to be attributed to a man more readily than was customary, which must certainly have influenced the people in their acceptance of Caesar's official apotheosis.

Opinion is divided as to whether Caesar allowed divine honours during his lifetime, though the fact that the Senate voted to give him these honours after his death shows that, officially at least, Caesar only received deification with all its implications as a dead hero - in much the same way as the Gracchi were honoured unofficially.

\section{c) Divine Honours in the Early Empire}

As has already been noted, Roman succession to the rule of the East where provincial governors were awarded divine honours, did much to strengthen the infiltration of Eastern influences into the Roman way of life. The development of the mystery-religions and the growth of scepticism in the traditional gods of the State prepared the ground for new religious forms which were more suited to the trends in the

1 Cicero, De Officiis III 80: "et ea res, si quaeris, ei magno honori fuit. Omnibus vicis statuae; ad eas tus et cerei...».

${ }^{2}$ Crcero, De Legibus II 22: "Deorum Manium iura sancta sunto. Humanos leto datos divos habento."

3 Ibid. II 19: «Ritus familiae patrumque seruanto».

4 Servius, Aeneidos commentarii (G. Thilo \& H. Hagen, Leipzig \& Berlin, 1923), VI 152: "apud maiores, et supra diximus, omnes in suis domibus sepeliebantur, unde ortum est ut Lares colerentur in domibus.» 
philosophy of the late Hellenistic world, stressing as they did that which was divine in man. Already in Roman religion, kindred elements were evident, as is seen in the worship of the Manes and Lares, but the genuine Roman restraint avoided the extravagance of worship of the Eastern cults. The popularity of Julius Caesar and the adulation paid to him by the enthusiastic masses led to the formation of the cult of Divus Julius after his death, which soon spread throughout Italy.

Even in its original form, the imperial cult was very much more complicated than would appear at first glance. Augustus was not divine in himself, and officially it was his Genius that was adored during his lifetime, but an absolute prohibition of the worship of the person of the emperor was not practical in the provinces or even in Italy outside of Rome, as Augustus was soon to discover. However, this worship was only allowed in conjunction with that of the Dea Roma, although deviations from this ruling are apparent from the inscriptions. At Rome, Augustus was at pains to link up the newlyestablished emperor-cult with the traditions rooted in the Republican era, in order to supply an ideal for the masses while respecting those men who were wary of innovations which were not firmly rooted in the past.

The divinity of the emperor was honoured in diverse ways - the inhabitants of the Roman Empire adored the Genius of the reigning emperor at least in the early stages of the development of the imperial cult, homage was paid to members of the imperial family, the 'domus Augusta', as well as to the imperial Lares, to the Victory of the emperor, and to the many deified qualities which seemed most significant of an emperor's reign ${ }^{1}$. In spite of their apparent differences, all these aspects of the imperial cult were derived from a similar concept, and were inspired by a similar sentiment, which was essentially a religious devotion to the master of the Roman Empire.

It is essential to realize that in dealing with his vast empire, Augustus adopted the safe principle that in the East it was permissible to regard

1 For example, Pax, Clementia, Justitia... W. M. Green, in Notes on the Augustan Deities, CLJ 23 (1927) pp. 86-93, gives a full list of deified abstractions, (apart from omitting Honos). I found evidence of the following abstractions on coins of the Ist Century in the British Museum - Abundantia, Aequitas, Aeternitas, Annona, Bonus Eventus, Concordia, Felicitas, Fides, Fortuna, Genius, Iustitia, Liberalitas, Libertas, Moneta, Pax, Pietas, Providentia, Salus, Securitas, Spes, Victoria, Virtus. 
the emperor in the same way as the previous ruler. Thus we have seen how, in Egypt, to the native, Augustus was the successor of the Ptolemies, and, as such, a divine figure. In the Hellenized East, a distinction was made between the Roman and non-Roman citizens; the natives continued their practice of worshipping Rome's representative, in this case, the emperor, along with the goddess Roma, while the Roman citizens were free to continue worshipping the traditional gods of Rome. Augustus refused to admit direct worship of his person, but official disapproval did not prevent such worship in the East. The cult of the Divi and the Genius of the living emperor gradually developed and came to hold a prominent position in the empire. Politically, this policy of Augustus was a tremendous revolution; this reorganization of the imperial religion in an attempt to unite the vast Roman Empire by a common bond of loyalty towards the person of the emperor, linked with the personification of the power of Rome. With the varied nationalities within its frontiers, the Roman Empire needed this unifying force which the emperor himself could supply; Roman citizens had to learn to recognize their common enemies, which were the enemies of the emperor.

It has already been noted that a usual form of honour was the renaming of towns in honour of the emperor and his family ${ }^{1}$. Apart from the honour attached, it was also a subtle method of propaganda insofar as the towns became constant reminders of the central authority in the person of the emperor. But the imperial cult was not merely an invention to form a bond of unity throughout the empire and to provide the people with a common object of loyalty - at the same time, there was a deep feeling of relief for the era of peace established by Augustus which found an outlet in the official and private forms of cult-worship. The political significance of the cult did, however, increase steadily, and, as Cyril Bailey has summed up

1 Pliny, Natural History IV 112 speaks of Augusta, a town belonging to the Bracae: «Bracarum oppidum Augusta.» cf. CIL II 6230 "Bracara Augusta», CIL II 4747 \& 4749 «Bracaraug. », 4869 «... caraug», 2423 «Bracara August.» (Tarraconensis), CIL XII 1385 «(brac)arum Augustanorum». PlinY, Nat. Hist. IV 119 mentions a town at Cadiz whose population have Roman citizenship and are called Augustans: "Habet oppidum civium Romanorum qui appellantur Augustani.» The same author also mentions tributary towns named Augustobriga and Caesarobriga (IV 118) and Caesarina (117). These are a few examples from the West; there are countless examples in the Eastern provinces. 
so aptly, "there can be no doubt that the worship of the imperial house had given new life and reality to the state cult» ${ }^{1}$.

When one considers the tremendous upheavals and factions during the last years of the Roman Republic, followed by the Golden Era of Peace brought about by the administration and reorganization of the provinces under Augustus and the developing sense of unity throughout the Empire, one is tempted to regret that there is so little in the Gospels to tell us of Christ's attitude towards this new world power which had swallowed up the Eastern Mediterranean soon after the rise of Pompey. The latter had sought to settle Eastern affairs by reorganization, and part of his work included the annexation of Syria, which, with Judaea, was organized as a province under the rule of the High Priests.

In the Eastern provinces, the emperor was revered as a god even during his lifetime, and although this position was not officially encouraged, the attitude of Augustus and his successors was to allow the Eastern mentality that mode of expression with regard to the worship of their ruler which was most acceptable to them. This attitude was especially prevalent in Asia Minor and Egypt, and the inscriptions are often addressed directly to the emperor himself, and not to his Genius or Numen.

The person of the emperor was, naturally enough, the centre and life-force of the imperial-cult; even Tiberius' attempt to minimize direct worship was not wholly successful and he was obliged to make concessions in his seemingly rigid policy. Even from the first years of his reign, Tiberius made it clear that excessive worship was contrary to his tastes, although he was willing to follow the precedents established by Augustus during his reign. Not only did Tiberius remain adamant in his refusals to the many letters and petitions which were sent by cities and provinces, asking permission to confer divine honours on him ${ }^{2}$, but he also showed himself to be extremely reticent

1 C. BaIley, Pbases in the Religion of Ancient Rome, California, 1932, p. 176.

2 TAC. Ann. IV 38, 4: "Perstititque posthac secretis etiam sermonibus aspernari talem sui cultum.» Tacitus maintains that Tiberius persisted in disdaining the honours offered to his person through his modesty, defiance and ignoble soull Cf. Dio LVII 8,3 declares that he would not allow any particular festivities in honour of his birthday. For Tiberius' correspondence with the Gythiates, cf. L. R. TAYLOR, Tiberius' Refusal of Divine Honours. TAPhA LX (1929) pp. 87-101. In particular, p. 89 ff., which give the reply of Tiberius. 
about the honours proposed for Livia ${ }^{1}$. He even promulgated an edict after the death of Augustus, advising the people to avoid an excess of zeal such as they had shown before the funeral of Divus Julius ${ }^{2}$.

In spite of the seemingly negative attitude of Tiberius towards divine honours, there are, however, examples of the cult of Tiberius in many Eastern cities, and even in the Western provinces; for instance, Pergamum honoured him as 'euergetes' before 4 A. D. ${ }^{3}$. Examples are not nearly so numerous as the inscriptions for the cult of Augustus, but they do witness to the fact that inspite of his seeming refusals, a cult was organized in honour of Tiberius throughout the empire. Rostovtzeff considers that the argument supporting Tiberius' inability to stem the tide of honours which were imposed upon him contrary to his will, is unconvincing, inasmuch as the emperor had the power to impose his will and put an end to such honours, if indeed this was really his desire ${ }^{4}$. Tiberius realized only too well that it would be farcical to attempt to occupy the place of Augustus, but, at the same time, he understood the importance of the imperial cult as a political institution, and seemed anxious to avoid impeding its development by any misplaced 'modesty' on his own part.

It is interesting to note the genuine need of the faithful of diverse cults and religions, which flourished particularly in the first century, to have some figure at the centre of their religion, who represented for them the supreme model of virtue. For the followers of the imperial cult, not only was the emperor the source of all virtues, in a

1 Dio LVIII 2, 2-3. Dio shows Tiberius in a bad light by declaring that he made no arrangements for any honours for Livia after her death, except for the public funeral and images and "some other small matters of no importance.» $\mathrm{He}$ forbade absolutely that she should be deified. Cf. also Suetonius, Tiberius 50, 4-5: "Tulit etiam perindigne actum in senatu, ut titulis suis quasi Augusti, ita et 'Liviae filius' adiceretur. Quare non 'parentem patriae' appellari, non ullum insignem honorem recipere publice passus est.»

2 TAC. Ann. I 8, 5: "Remisit Caesar adroganti moderatione, populumque edicto monuit ne, ut quondam nimiis studiis funus diui Julii turbassent, ita Augustum etc.»

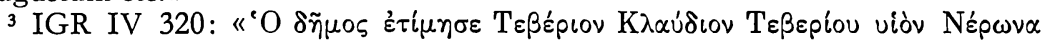

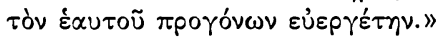

${ }_{4}$ M. RostovtzefF, L'empereur Tibère et le culte impérial. RH 163 (1930) p. 23. The inscriptions of Gythium (14-19 A.D.) show the attitude of Tiberius towards honours for himself and his family. The text for these inscriptions is given by L. Wenger, Griechische Inschriften zum Kaiserkult und zum Grabrecbt. ZRG 49 (1929) pp. 308-328. Other references: TAYLOR, Divinity p. $231 \& 239$ and Tiberius' Refusals TAPhA LX (1929) pp. 87-101. H. SEYRIG, Inscriptions de Gythion. RA XXIX (1929) pp. 84-106. 
certain sense, but these virtues were themselves personified and honoured, to a greater or lesser degree.

Though for the Christians, it was Christ who was the central figure, the ideal and model of all virtues, there is no parallel personification of the virtues of Christ, even for the most ardent of his followers. Yet there are great similarities between the position of the pagan rulers of the Roman Empire and that of Christ in the Christian world; similarities which find expression in the divine titles, the ceremonial and the formulae of the official cult-worship. Christianity is a mystical religion inasmuch as there is more emphasis on the interior development of the soul, and for Christians, especially in the first century, Christ was a living and divine person. Deissmann has drawn our attention to the many expressions and titles common to both the imperial cult and Christianity, and these will be discussed in a later chapter. Suffice it to say here that these were deliberately chosen by the Christians insofar as they were appropriate and fitting, although how far they were used in contrast to those used for the emperor is far more difficult to judge ${ }^{1}$.

The exteriorization of the Christian worship was built up with existing material, adapted and remoulded to suit the needs of the early Church. It is impossible to say with any degree of certainty how far the emperor-cult influenced the early Christian rites - the imperial cult was in itself far more complex than would seem at first sight, for it is impossible to generalize or to apply a principle or idea to the whole empire.

At the time of Christ, the great diversity of religious beliefs flourishing within the Roman Empire did little to create that sense of unity which Augustus and his successors desired. The emperors used their position to put forward and foster the idea of their divinity throughout the empire, as a means of strengthening that unity so vital, yet so difficult to achieve in an empire of that size and containing such a diversity of peoples. Christ, claiming as he did to be both God and man, offered a real challenge to those rulers who strove to encourage the myths that they were 'epiphanes' gods. In order to salute and reverence Christ as God, the early Christians used similar formulae to those used currently in the imperial cult and for official state apotheosis.

1 A. Deissmann, Light from the Ancient East, London, 1910, p. 342. 


\section{NEW TESTAMENT IMPLICATIONS TOWARDS THE ROMAN EMPIRE AND THE EMPEROR}

\section{a) The Attitude of Christ towards the Roman Empire}

As an introduction to the whole question of possible New Testament references to the imperial cult, I intend to give a brief «resumé» of the attitude of Christ and St. Paul towards the Roman Empire in general. There is a similarity between the attitude of Christ as seen through the Gospel writings and that of St. Paul in his Epistles with regard to the Roman Empire, although the latter goes into even more detail and writes more directly on the subject as was fitting for a loyal subject of Rome. Both refer to the State as a legitimate power ${ }^{1}$, and their followers are encouraged to abide by its laws in all that comes under its jurisdiction, presupposing at the same time, that it was possible to 'render to God' his due.

Reviewing the mass of inscriptions and monuments bearing witness to the flourishing imperial cult, it would seem impossible to reconcile these facts with the apparent tolerance of New Testament writings, excluding the Apocalypse. However, it must be borne in mind that the aim of these writings was far from political, and when the Roman Empire, was mentioned, it was seen only insofar as it remained within its legitimate limits. The demands of the early emperors for cultworship was singularly modest and it would seem that the rendering of honours came more from a desire of the people, who welcomed the era of peace brought about by the establishment of the empire, rather than an authoritative imposition of these honours by the emperor himself.

There was no question at this early stage of compulsory worship, and the Jews were largely left to themselves when there was a question

1 The notion that the State could be accepted as a legitimate power so long as it kept within its rights, was never explicitly stated in the New Testament. 
of a religious nature. During the first half of the first century at least, followers of Christ were looked on as members of a Jewish sect, and they could therefore enjoy the same privileges and exemptions as the Jews. Obviously there were not the complications which developed during the second century, when both Christianity and the imperial cult had thrust down their roots more deeply and both were more aware of their demands and ideals.

The much-discussed episode of the paying of the tribute-money was one such occasion when Christ spoke of the lawful aspect of the Empire, without considering its excesses, which were later regarded as infringements of the sovereignty of God, and which were so definitely condemned in the Apocalypse. During the reigns of Augustus and Tiberius, direct worship of the emperor was frowned on in theory at least, although in the East, Oriental influences were too strong and the emperor was forced to adapt his policy to the Eastern mind, and received direct honours as had been the due of the Eastern rulers before him.

There are two main aspects of this particular episode of the Gospel narrative ${ }^{1}$, and both are sufficiently relevant to bear development in these pages, although perhaps only indirectly concerned with imperial worship. The first point is obvious; the legitimacy of paying taxation to the Roman State, the religious policy of which was in opposition to the teaching of Christ. It has been maintained that the paying of such taxes was a direct contribution towards the prayers and sacrifices offered for the well-being of the emperor, yet it is most uncertain whether this implication was realized by the ordinary people of the time; it was generally looked on as another tax imposed by the State. Yet the members of Herod's party who introduced this topic with the words recorded by St. Matthew ${ }^{2}$ : «... we know... that you are not afraid of anyone, because a man's rank means nothing to you» implied that most men of the time recognized distinctions between men, the most obvious case being that of the emperor, who was the object of worship for so many of his subjects, whether directly as was the case in so many of the Eastern cities, or indirectly through the worship of the emperor's Genius.

The second aspect is less apparent and concerns the indirect way of promulgating the imperial cult by means of a contemporary

1 Matt. XXII 16-22. Mk. XII 13-17. Lk. XX 25.

2 Matt. XXII 16. 
method of propaganda as was used on the coins. At this stage, coins were in general use and passed freely from hand to hand in commerce; thus it was possible to influence citizens all over the Empire in a relatively short time by means of the coinage system with its various symbols and captions.

At this period, when the coin was looked upon as a political symbol much more than it is today, certain emblems were regarded as idolatrous, and this in itself complicated the issue to a very great extent ${ }^{1}$. The silver coin in question is generally considered to have been a denarius of Tiberius ${ }^{2}$, but although it is possible, there is no means of proving this view. The picture or bust of the emperor was not in itself idolatrous, but the denarius contained the title of 'Divus' which might have provoked some of the more devout Jews to attempt resistance to the tax. Loewe suggests two interpretations of the action of Jesus when he asked for a silver coin and displayed it to those around him; the first is that in all probability there were at least some provincials who did not understand Latin fluently, and for whom the term 'Divus' would have had little or no meaning, and they could therefore make transactions with such coins without the slightest scruple that they were offending God.

The second possibility is that Christ concealed the idolatrous symbols on the reverse of the coins and showed merely the laureated head

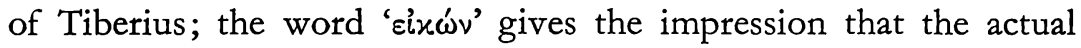
head of the emperor was on view, but even this image of the person was the object of divine honours would have been intolerable to many Jews or early Christians.

Christ's words underline the distinction which he makes between the interests of the world with those of his Kingdom, 'which is not of this world', yet $\mathrm{He}$ makes no pronouncement on the burning question as to whether the effigy of the emperor on Roman coins should be considered idolatrous or not, for this was not the point under consideration. Christ sums up his teaching on this point with the words, "Give back to Caesar what belongs to Caesar - and to God what belongs to God,» and $\mathrm{He}$ thereby shelves the whole political question by separating the two spheres of authority ${ }^{3}$.

1 H. Loewe, Render unto Caesar. Cambridge, 1940, p. 14.

2 Ibid. p. 97. Cf. Mattingly, BMC I pp. 125 ff. Pl. B 5.

3 Cf. G. H. Dalman, The Words of Jesus, Edinburgh, 1902, p. 138: «His verdict as to the tribute money shows that he did not consider the political dominance of 
Other situations arose later with the persecutions under Nero and Domitian which made it impossible to compromise between the allegiance due to God and that due to Caesar since the latter had usurped those honours which belonged to God alone, and such a concession could have been interpreted as condoning those practices which were so obviously in opposition to Christian beliefs and teaching. This does not exclude the fact that it was often the people themselves who took the initiative in the rendering of honours to the emperor, especially in the first part of the first century, though this would not change the situation as far as a Christian was concerned.

In the situation at the end of the century, there was less chance of remaining neutral, and this accounts for the abrupt change in the tone of the Apocalypse; in similar circumstances Christ Himself would have been obliged to condemn such blatant excesses on the part of the pagan emperor, whose self-deification clashed directly with Christian monotheistic thought.

\section{b) The Attitude of St. Paul towards the Emperor}

The position of Paul in the early Church was particularly significant, for as a Roman citizen he would have had many of the loyalties of his fellow citizens, including the respect due to his emperor, the rendering of certain honours and, as a Jew, the recognition that all lawful authority comes from God ${ }^{1}$. One of the most frequently-quoted passages from the writings of St. Paul is found in his Epistle to the Romans, written during the Quinquennium Neronis, 54-59 A. D. when Roman citizens had become aware of the advantages of the security ensured by the Pax Romana. Knowing that Paul had lived through the reign of Caligula and most of Nero's, it seems strange

the Romans to be any infringement of the sovereignty of God.» For other literature: E. Peterson, Göttliche Monarchie. ThQ 112 (1931) pp. 537-564. St. Loesch, Deitas Jesu und antike Apotheose. Rottenburg, 1933.

1 Rom. XIII 1-7. Cf. J. HÉrIng, La Première Epître de saint Paul aux Corintbiens. Neuchâtel/Paris, 1949, p. 26 ff. Il pense que l'Etat romain a réellement reçu de Dieu la mission de maintenir la paix et la justice dans le bassin méditerranéen. Cf. also Fr. Leenhardt, L'Epître de saint Paul aux Romains. Neuchâtel, 1957, pp. 181-184. This author puts forward three traits in the attitude of St. Paul towards the public authorities: it is positive, it is critical but at the same time, there is a characteristic reserve - "the attitude of being submissive in no way implies being servile.» 
that he felt able to advocate such a policy towards authority, even though the procurators concerned might have been worthy and competent officials.

St. Paul starts this chapter with the admonition that one "must obey the governing authorities "; with these words, he passes to this urgent and complex problem, the attitude of the Christian to the secular authority over him - he affirms the principle of the divine origin of all power. Paul advocates subjection: "anyone who resists authority is rebelling against God's authority, and such an act is bound to be punished». Thus Paul makes it clear that the civil life of the empire may not be alienated from the religious and moral life; it is part of the whole which may not be ignored without affecting the whole plan of the empire.

Yet if these words of St. Paul meant that he was prepared to bow before any claim of the State, it would be impossible to reconcile them with the teaching of Christ, that one must first fulfil one's obligations towards God, and then the duties to legitimate authority insofar as it remained within its own limits. In all these discussions, it is necessary to emphasize that the important word is 'legitimate', and St. Paul is dealing with this point only up to the stage when the authority was still within its own rights ${ }^{1}$.

O. Cullmann suggests that if the background of this passage is considered, and the context carefully examined, it is realized that St. Paul is by no means advocating total subjection to the State; in fact, he is pointing out that though the State is often opposed to the Christian way of life, the Christian is to submit himself to the laws of the State as its presence is willed by God ${ }^{2}$.

In relation to another text of St. Paul ${ }^{3}$, Rom. XIII. 1. stands in the background, a seeming contradiction, but there is no denial of the right of the State to administer its own affairs. Yet there is a definite limit to Paul's concept of the State; if the State were of a divine nature, the Christians could present themselves bəfore the State courts.

1 One must keep in mind, however, that the word 'legitimate' was never used in the New Testament. As the Rév. P. SPIcQ has pointed out to me, "en réalité, saint Paul fait de la théologie et non de l'histoire. Le Ier siècle est aussi loin que possible de nos concepts modernes."

2 O. Cullmann, The State in the New Testament. New York, 1956, p. 57.

3 I Cor. VI 1. 
These three passages give an idea of Paul's views on the Roman State which are close to Jesus' own. Christians must give the State its due, but St. Paul stops at this point; he does not mention the position of Christians living under a totalitarian régime which encroaches on the rights and privileges of God, yet we cannot imagine the fiery Paul accepting that his disciples blaspheme against God, or give the emperor those titles which were considered divine, and therefore reserved for God alone.

The sense of loyalty towards the emperor, which seems so apparent in Paul, is seen again in a letter written to his disciple Timothy, where he advocates prayers for those in authority, especially for kings and others in high stations ${ }^{1}$. Perhaps one reason why St. Paul emphasizes this duty is because he is well-aware of the Jewish tendency to rise against the Emperor, which might conceivably pass into the infant Christian church, especially during periods of stress and persecution.

At all events, Suetonius, writing about the happenings of the reign of Claudius, gives the impression that these risings were a common feature of mid-first century Rome, when he records that Claudius exiled from Rome those Jews who were continually rising up at the instigation of a certain Chrestos ${ }^{2}$. The terms 'Chrestos' and 'Chrestiani' are used by first and second century writers, when referring to Christ or his followers, so it is possible that these Jews were members of the early Christian communities. St. Paul is aware how this state of affairs could influence the Christian communities in their attitude

1 I. Tim. II 2: «Prayers should be offered for kings and others in authority, so that we may be able to live religious and reverent lives in peace and quiet. 》 Cf. C. SpicQ, Les Epitres Pastorales. Paris, 1969, pp. 359-363, for bibliography. The fact that St. Paul is advocating prayers for the emperor as opposed to the common pagan practice of praying to the emperor, or offering to him through the medium of statues and images an adoration normally reserved for the State gods, shows the different attitudes of the Christian and the pagan towards their emperor. "Pour ceux-ci (the pagans) le prince divinisé n'a pas besoin de la grâce; il est lui-même le Sauveur. " Similarly, Christians did not make their oaths by the Genius of the emperor, but by his health, which, as Tertullian argued, was certainly more fitting, as it was customary to exorcize geniuses in order to drive them out of men. Cf. Apol. 32,3: "Ceterum daemonas, id est genios, adiurare consuevimus, ut illos de hominibus exigamus. $)$

2 SuEt. Claud. 25, 11: «Judaeos impulsore Chresto assidue tumultuantis Roma expulit.» Cf. H. Mattingly, Christianity in the Roman Empire. Otago, 1955, p. 30. 
towards the emperor; he advocates prayers also that the non-Christians may recognize the loyalty of the Christians and then leave them in peace.

Similar types of prayers for the emperor continued to be encouraged by Christian writers, even after periods of persecution and suffering at the hands of the imperial authorities. Among various examples, two excerpts from the writings of Tertullian underline the Christian duty of praying for the emperor, in spite of the writer's awareness of former persecution of the Christians ${ }^{1}$. Tertullian gives yet another reminder to his readers to pray for the State and its rulers, including in this exhortation world peace and the last days of the world ${ }^{2}$.

St. Peter likewise realizes that due honour should be paid to the emperor; he understands that every man has his due, which should be carefully thought out, and then rendered accordingly: «Have respect for everyone and love for our community; fear God and honour the emperor" ${ }^{3}$. The implication of these words is that a wise Christian would realize what degree of honour is due to an equal, a master or to Caesar himself. This presupposes, however, that the emperor would not demand rights or honours which went beyond the limits of his due, and here again, Peter does not give any indication to guide Christians who were victims of such demands. It is not that St. Peter is deliberately simplifying the situation between emperor and Christian; it is more that this situation has not yet become complicated by a regular system of enforced Caesar-worship, and Peter is writing from the same angle as St. Paul inasmuch as he is considering the empire and the emperor as legitimate forces, which represent God in

1 Tert. Apol. 30, 4: «Precantes sumus omnes semper pro omnibus imperatoribus, vitam illis prolixam, imperium securum, domum tutam, exercitus fortes, senatum fidelem, populum probum, orbem quietum, quaecumque hominis et Caesaris vota sunt.»

2 Ibid. 39, 2: "Oramus etiam pro imperatoribus, pro ministeriis eorum et potestatibus, pro statu saeculi, pro rerum quiete, pro mora finis.»

3 I Pet. II 17. Reverence to God is not incompatible with the honours due to the emperor as head of the State. Obedience in itself was a sufficient proof of loyalty, until the later measures enforcing emperor-worship were devised. Cf. C. H. DodD, The Epistle of Paul to the Romans. London, 1932, p. 202: "Even when Christianity had been outlawed, the duty of loyalty to the Empire was put just as strongly in I Pet. II 13-17. It remained a steady principle of the Church all through, although the measure of 'non-co-operation', which was made inevitable by the intimate association of Caesar-worship, gave the appearance of an imperfect loyalty.» 
their own limited sphere; he is not attempting to clarify the problems which would arise when such powers were abused by over-ambitious rulers.

In his epistle to the Romans ${ }^{1}$, St. Paul refers to Satan who will eventually be crushed by God, the author of peace. It is at least possible that this is a disguised reference to the adversaries who were disturbing the peace of the Christian Church at this time, and this could apply in a special way to the emperor. But St. Paul does seem to make a distinction between the religious and the political spheres ${ }^{2}$ and distinguishes between the claims of Christ and those of the emperor, for, as he sees it, the emperor exercised his jurisdiction over purely temporal concerns, whereas the reign of Christ will be over those who have risen from the dead, and Satan could be the personification of all the claims for divine honours, which allow the emperor to assume that which belongs to God alone. There is no assurance that St. Paul was indeed referring to this particular danger, but he was certainly warning the Romans to beware of some peril which was threatening the early Church ${ }^{3}$.

In St. Paul's writing to Titus, there is a short reference to the Christian's duty to the outer world, and, in particular, to those in authority, which implies obedience to the government: «Remind them that it is their duty to be obedient to the officials and representatives of the government» ${ }^{4}$. A like command would be necessary for those Christians who regarded their allegiance to Christ as an exemption from allegiance to the emperor.

It is interesting to speculate just how far St. Paul, as a loyal citizen of Rome, would have been prepared to continue carrying out the

1 Rom. XVI 20.

2 Cf. Cerfaux \& Tondriau, Culte des souverains, p. 390.

${ }^{3}$ Cf. Dodd, Epistle to the Romans, p. 243.

4 Tit. III 1: "Admone illos principibus et potestatibus subditos esse, dicto oboedire...» Titus is told to remind the Christians of Crete to be submissive to those in authority but this advice was intended for the whole Church. It was a reminder that Christians should avoid all political agitation which could result in the restriction of their activities, and even result in persecution. Cf. J. MofFat, The Pastoral Epistles. London, 1936, p. 171. Also, C. SPICQ, Les Epîtres Pastorales II, p. 646, stresses that not only were Christians bound to give this 'submissive loyalty' to the State, but that the New Testament gives no foundation to a 'théologie de la révolution' which is currently advertised in certain quarters. The verb used by St. Paul ' $\pi \varepsilon \varepsilon \theta \rho \rho \chi \varepsilon \tilde{\imath} \nu$ ' implies the active participation in the obligations and good works of the State. 
commands laid down by the Roman government with regard to emperor-worship; just how far the 'submissive loyalty' of subjects was justifiable for Christians at a slightly later epoch, he does not give a hint. There is much the same problem in distinguishing the rights of authority in the contemporary world, and determining how far these rights come into conflict with those of religion.

\section{c) The Attitude of Pilate and the Significance of the Expression 'Friend of Caesar'}

Encroaching on the rights of the accepted authority was one of the trumped-up charges brought against Jesus by the seeming loyalties of the Jews, who declared adamantly to Pilate: "If you set him free, you are no friend of Caesar; anyone who makes himself king is defying Caesar ${ }^{1}$. Already Christ had shown that he had no intention of introducing some kind of revolutionary kingship which would set him up as the direct rival of Caesar: "Mine is not a kingdom of this world" ${ }^{2}$, but Pilate realized well enough that there was an element of truth in what they were saying, all the same ${ }^{3}$; to shut his eyes to the fact that Jesus did have a following and had made certain definite, though somewhat vague references to his kingdom, would show a lack of interest in the concerns of Caesar.

Under Tiberius, a similar negligence could be considered grave when a praetor asked the emperor whether the crime of lese-majesty should be punished, the emperor replied that the laws should be applied, upon which the laws were applied in the harshest way

1 Jn. XIX 12. A. N. Sherwin-White, Roman Society and Roman Law in the New Testament. Oxford, 1963, p. 100f. shows how the Jews used political 'pressurizing' to get their way.

2 Jn. XVIII 36. Cf. P. M.-J. Lagrange, Evangile selon saint Jean. Paris, 1936, p. 475. G. H. MACGREgor, The Gospel of John. London, 1928, p. 336, remarks that in the Synoptics, Christ did not explain the term 'King of the Jews', and left Pilate to interpret it in a way a Roman naturally would, that is, as a rival to Caesar. Whereas in St. John's Gospel, Jesus explained the implications behind the words, stressing that His Kingdom should not be thought of as a worldly reality.

3 Lagrange, Saint Jean, p. 484: "Pilate reconnaît qu'il y a quelque chose de vrai dans les prétentions de Jésus-Christ à la royauté...» 
(atrocissime) ${ }^{1}$. It would appear from these words that there were heavy penalties to pay by those who attempted to usurp the power and position of the emperor, and it would be difficult to explain the nuances of the claims of Christ, which, on a material level at least, did not comprise a threat to the position of the emperor.

The laws against lese-majesty were strengthened during the reign of Tiberius, and crimes which had lost their seriousness to a certain extent in previous years, were once more subject to extremely severe punishments.

It is possible that the Jewish threat held a deeper significance than the obvious sense of remaining in the emperor's favour, for to be a 'friend' of the ruler perhaps signified an honorary position which would have been greatly coveted during the early empire. This statement was an undisguised attempt on the part of the Jews present, to play on the fears of Pilate, whose livelihood depended upon his remaining an 'amicus Augusti'. To understand the implications behind this title, its use in Hellenistic times and during the early Empire will now be considered in some detail.

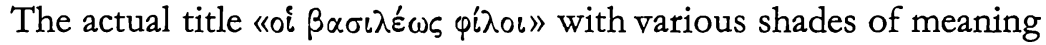
is strongly attested during the Hellenistic period under the Seleucids and Lagids '; the privileged position of the 'king's friends' is clearly discernable in the texts, and it gradually developed into a complicated system with varying titles according to the degree of intimacy enjoyed by the 'friend'. There does not seem to have been any direct responsibility of the court attached to this title of 'friend' during the Hellenistic period, but the king's friends certainly had access to

1 Suet. Tib. 58, 1: «Sub idem tempus consulente praetore an iudicia maiestatis cogi iuberet, 'exercendas esse leges' respondit et atrocissime exercuit.» TACITUS (Ann. I 72, 4) also notes that Tiberius renewed the law against crimes of lesemajesty; renewal because a law of this name had existed previously, which involved various crimes - treason in the army, seditions in the capital and actions against the majesty of the Roman people: "Non tamen ideo faciebat fidem civilis animi, nam legem majestatis reduxerat: cui nomen apud veteres idem, sed alia in judicium veniebant...». SuEtonius (Dom. XI 5) mentions «the usual punishments of their ancestors" being meted out to several persons who were convicted of the crime of lese-majesty during the reign of Domitian: "Quosdam maiestatis reos in curiam induxerat, et... facile perfecerat, ut etiam more maiorum puniendi condemnarentur.»

2 Bikerman, Institutions, pp. 30-40. Very full notes and bibliography is given by P. C. SpicQ, Agapé dans le Nouveau Testament III. Paris, 1959, pp. 239-245. Also, E. Bevan, Hist. des Lagides, pp. 311-316. For 'amicus', cf. Thesaurus Linguae Latinae I cols. 1902-1913. Leipzig, 1900. 
the royal person from the early morning onwards - at the murder of Hermias, Antiochus III went for his early morning walk which had been prescribed for him by his doctors, accompanied by «those of the king's friends who were privy to the plot»; Polybius, who recounts this episode, states carefully that it was at a far earlier hour than usual, and for this reason, the rest of the king's retinue was not with him ${ }^{1}$. Polybius makes another reference to this custom of the king's friends being with him from the early hours of the morning, stating that it was the friend's custom to flock to the king's tent at dawn each day ${ }^{2}$.

The king's friends not only shared with him the life of the court, his travels and his fatigues, but they also, on occasion, had to share his death, as in the case of Seleucus VI Epiphanes Nicator, who tried to obtain money from the people of Mopsuestia by extortion. The indignation of these people fermented into revolt, and they solved the problem for themselves by setting fire to the king's palace, burning the king along with his friends ${ }^{3}$.

That the king's friends had some military capacity seems evident from Josephus who speaks of the two orders of military aristocracy in the Macedonian kingdom - 'Kinsmen and Friends' ${ }^{4}$. There was also some kind of gradation or hierarchy among the king's friends which Seneca regards as a degradation for the king himself. G. Gracchus, and later Livius Drusus established the custom of separating their friends into groups; those whom they received privately and those who were received in audience in small groups, and others who were received 'en masse'. Thus, Seneca remarks cynically, the king had friends of the first class, friends of the second class but never true friends, for in this context, a friend is one who has a number for paying homage to the king 5 .

Under Augustus, this title of friend, 'amicus Augusti', was adopted for imperial usage. Suetonius makes reference to the 'friends' of the

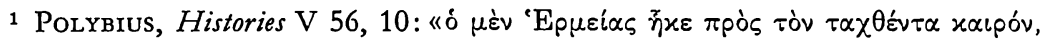

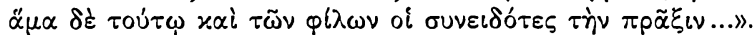

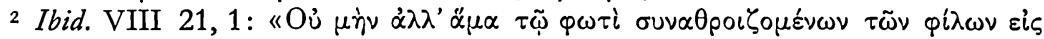

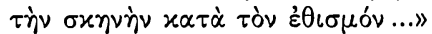

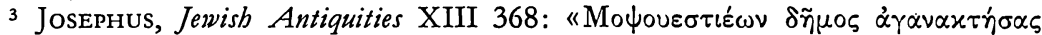

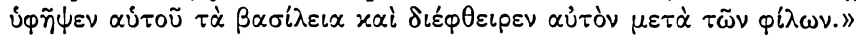

${ }_{4}$ Jos. Ant. XII 298. Cf. E. Bevan, The House of Seleucus, II, 1902, pp. $280 \mathrm{ff}$.

5 Seneca, De Beneficiis VI 34,1: "Consuetudo ista uetus est regibus regesque simulantibus populum amicorum discribere...» 
emperors, and together with those references of Tacitus and Dio each emperor had his following of friends. This practice was adapted to suit the special needs of the empire, and various changes crept in to the position of the 'friends', which were not part of the Hellenistic practice, such as the receiving of official or semi-official functions. Under Augustus, for example, the Senate was reformed; its numbers were reduced, and its original importance was restored. Suetonius adds the detail that ten senators, chosen from among the emperor's friends, stood around his chair ${ }^{1}$. The friends of the emperor are mentioned in a less official capacity by this same author; when assisting at the circus games, Augustus accepted the hospitality of his friends and freedmen by settling himself in one of their diningrooms ${ }^{2}$. Therefore, although under Hellenistic rulers their friends did not enjoy any official positions, this state of affairs was modified under the Empire, and the 'friends' were not only attached to the emperor himself, but also to members of his family, and even to his favourites.

Shortly after the death of Augustus, in 15 A. D., a revolt of the three legions of Pannonia was put down with great difficulty by Drusus. The soldiers, who were searching for a pretext for rebellion, menaced the praetorians and the friends of Drusus, hoping in this way to ferment some kind of violence. It is significant in this context that the term 'friend' is linked with a member of the imperial family who was not the emperor - here it is the son of Tiberius who is concerned ${ }^{3}$.

The title of 'friend' as a recompense for a service or pronounced loyalty to the imperial cause is obvious in various texts; while describing the vices of Tiberius, Suetonius tells how the emperor proclaimed in his letters of nomination that Pomponius Flaccus and

1 Suetonius, Aug. 35,1: «decem ualentissimis senatorii ordinis amicis sellam suam circumstantibus. »

2 Ibid. 45,1: «Ipse circenses ex amicorum fere libertorumque cenaculis spectabat». Dio LVII 11, 4 mentions how Augustus went to the houses of imperial freedmen at the occasion of festivals, but he does not make any reference to the 'friends'.

3 TAC. Ann. I 27, 1: "Postremo deserunt tribunal, ut quis praetorianorum militum amicorumve Caesaris occurreret, manus intentantes, causam discordiae et initium armorum...» 
L. Pison were his dearest friends at all times ${ }^{1}$. Pomponius Flaccus received the province of Syria where he died in $33 \mathrm{~A}$. D., while L. Pison received the prefecture "of the town». This supports the theory that Pilate received Judaea as the 'friend' of Tiberius, or rather, of Sejanus ${ }^{2}$, and that the taunt made by the crowd which was urging that Christ should be crucified, and which finally broke down Pilate's resistance: "If you set him free, you are no friend of Caesar», held a particular meaning for Pilate, reminding him of the special intimacy allowed by the emperor to a certain number of his followers, an intimacy which Pilate felt he could not afford to lose.

Under Caligula, we meet his 'friends' applauding the building activities of their emperor; having built a bridge of boats from Bauli (Baiae) to Puteoli (the modern Pozzuoli) with a total length of over three-and-a-half Roman miles, Caligula spent the following two days visiting his masterpiece, and on the second day he drove a chariot followed by a group of praetorians, and then a number of vehicles filled with his friends ${ }^{3}$. This event took place in 39 A. D. and Dio gives the same account of how Caligula's 'friends' and associates followed in their flowered robes, then came the army and the rest of the throng, each man dressed according to his personal taste ${ }^{4}$.

Claudius too was surrounded by his 'friends' even in the early part of his reign and men were admitted into this group of the emperor's 'friends' as a mark of gratitude for their loyalty and support towards their sovereign. It was in this manner that Galba became one of Claudius' friends; after the death of Caligula, many tried to

1 SuEt. Tib. 42, 3: «codicillis quoque iucundissimos et omnium horarum amicos professus ». For references to Sejanus as a friend of Tiberius, cf. Dio LVIII 2,7 and Suet. Tib. 65, 1.

2 As P. SpICQ has pointed out, it would have been Sejanus who conferred the title of 'friend' on Pilate, as well as the province of Judaea, for Tiberius had already withdrawn to Capri in 27 A. D. The 'friends' of Sejanus are conspicuous at his downfall, when the majority hasten to deny that such a friendship had ever existed. M. Terentius, a Roman knight, stands alone as a former friend of the ex-favourite, who had the courage to admit it in a discourse before the Senate, acknowledging the fact that though it might be more prudent to deny any friendship, he admitted that he had aspired to this position, which, once it had been attained, brought him much happiness. TAC. Ann. VI 8,1.

3 SuEt. Caligula 19,2: "Et in essedis cohorte amicorum.»

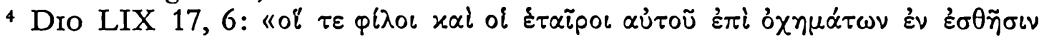

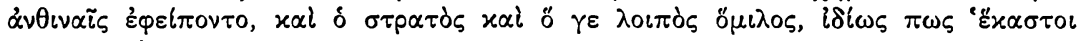

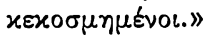


take advantage of the period of turmoil, but Galba preferred to sink his personal ambitions for the cause of peace ${ }^{1}$. Tacitus tells how later Galba had an unpardonable weakness towards his friends and freedmen ${ }^{2}$.

Seneca, one of the nearest of the friends and advisers of Nero, was constantly aware of the court jealousies which surrounded him and was finally driven to ask if he might retire, since his position was far from satisfactory. He tells Nero that it is not from personal motives of bitterness that he is prompted to offer his resignation; "You have given all that a prince could give to a friend; I have received all that a friend could receive from a prince» ${ }^{3}$.

The custom of having 'friends' around the emperor continued under the Flavians; a seemingly unimportant reference is made by Suetonius, who relates how Vespasian, having read his correspondence and the official court reports, put on his shoes and outdoor clothes while his friends were allowed in to greet their emperor ${ }^{4}$. It was the group of friends around Domitian who finally brought about his death, for this emperor fell victim to a plot which had been arranged by his most intimate friends and freedmen, aided by his wife, after he had made himself hated by all those in his immediate circle, as well as in general by all his subjects ${ }^{5}$.

From these texts, it is impossible to prove conclusively that all these references to 'friends' imply the honorary status which was so common under the Hellenistic rulers, but it is obvious that the friends of the emperors enjoyed a particular intimacy with them, and that the title of 'friend' was conferred on a man for reasons of imperial gratitude, such as the reward for loyalty.

1 Suet. Galba 7,2: «per hoc gratissimus Claudio receptusque in cohortem amicorum.»

2 TAC. Hist. I 49,5: «amicorum libertorumque... sine reprehensione patiens.»

3 TAC. Ann. XIV 54,1: «tu, quantum princeps tribuere amico posset, et ego, quantum amicus a principe accipere.»

4 Suet. Vesp. 21,2: "In principatu maturius semper ac de nocte uigilabat; dein perlectis epistulis officiorumque omnium breuiariis, amicos admittebat, ac dum salutabatur, et calciabat ipse se et amiciebat..." We hear earlier (ibid. 13,1) how Vespasian showed great indulgence towards the liberties of his friends: "Amicorum libertatem... lenissime tulit.»

5 Ibid. Dom. 14,1: «Per haec terribilis cunctis et inuisus, tandem oppressus est conspiratione amicorum libertorumque intimorum simul et uxoris.» 


\section{REFERENCES TO THE IMPERIAL CULT IN THE APOCALYPSE}

\section{The 'Blasphemous 'Titles' of the First Beast}

"Then I saw a beast emerge from the sea: it had seven heads and ten horns, with a coronet on each of its ten horns, and its heads were marked with blasphemous titles...» ${ }^{1}$.

This first beast is introduced as "the beast that comes up from the abyss ${ }^{2}$ and the details of its appearance are entirely symbolical. The beast comes up out of the sea, which is the traditional source of evil, and it has ten horns and seven heads ${ }^{3}$. Many critics see this first beast as the epitome of the power and influence of the Roman Empire 4, and, although this is 'sufficient' as an explanation,

1 Apoc. XIII $1 \mathrm{ff}$.

2 Ibid. XI 7.

3 L. BRUn, Die römischen Kaiser in der Apokalypse. ZNTW 26 (1927), pp. 128151, gives a detailed description of the various interpretations of this problem.

${ }^{4}$ B. Rigaux, L'antécbrist et l'opposition messianique dans l'Ancien et le Nouveau Testament. Paris, 1932, p. 379, sees the first beast as «le symbole des forces humaines antichrétiennes, spécialement du pouvoir civil en tant que persécuteur des croyants.» The beast «n'est donc ni Néron, ni l'Empire romain, ni une entité purement eschatologique, ni une idéalisation de la cité du mal». R. H. Preston \& A. T. Hanson, The Revelation of St. John the Divine, London, 1949, p. 95; for them, the first beast represents first and foremost the Roman Empire, and this Empire is summed up and completed in the figure of one of its worst rulers. M. E. Borsmard, L'Apocalypse. Paris 1950, p. 60, sees the first beast as a symbol of the Roman Empire, which was a type of all the powers which set themselves up against the Church. A. Farrer, The Revelation of St. Jobn the Divine, Oxford, 1964, p. 151, describes it as «epitome of political religion", while for T. F. GLAsson, The Revelation of Jobn, Cambridge 1965, p. 79 f., it represents «the persecuting Roman Empire, concentrated in Nero, who was expected to return to earth... At first, the monster is the Roman Empire, but as the chapters develop, it comes to stand for a single ruler with supernatural powers and with a deadly hate against the servants of God.» The Jerome Biblical Commentary, (ed. R. E. Brown, J. A. Firzmyer \& R. E. Murphy, New Jersey, 1968), pp. 483. 62. gives a slightly wider interpretation in the Roman Empire, "the archetype of secular powers which persecute the Church». 
it seems to be only part of the whole. Attempts have been made to reconcile the seven heads with seven emperors, but even the more likely involve many presuppositions which, in turn, are not completely convincing. It is perhaps nearer the meaning of the author to accept these numbers in an apocalyptic sense rather than take them too literally.

There are striking parallels between the four beasts in the Book of Daniel ${ }^{1}$ and this beast of the Apocalypse. All rise from the sea; the ten horns on the fourth beast of Daniel are paralleled in the Apocalypse by the ten diadems, emblems of kingship, which decorated the horns. Daniel prophesied that Antiochus Epiphanes would "make war on the saints», and we find likewise in the Apocalypse that the first beast «was allowed to levy war on the saints and triumph over them " ${ }^{2}$. Similarly, the 'blasphemous titles' of the latter are prefigured in the fourth beast of Daniel, which had a mouth «that talked boastfully... and boastfully shall he challenge the Most High».

The Roman Empire as such was not evil and it could only be so recognized in its abuses. The most widespread and malignant abuse, as far as the Christians were concerned, was the organization of the imperial cult in such a way as to give to men those honours which should be reserved for God alone. Therefore, the first beast is a symbol of the Roman Empire insofar as it abuses its rights; it is that aspect of life in the Roman Empire which, by its exaggerations had taken over the prerogatives of God ${ }^{3}$. This would apply particularly to the imperial cult, especially in the latter part of the first century, when, by the statues, sacrifices, prayers, acclamations and all the other forms of cult-worship, the emperors were receiving divine honours and titles. The imperial cult was a sufficiently political institution to favour this interpretation ${ }^{4}$.

A Christian of the first century who believed in one God, and who reserved for this God all the divine titles which his pagan countrymen lavished on the emperor and his family, would understand without difficulty the implications of the author of the Apocalypse when he wrote that the heads of the beast "were marked

1 Dan. VII 1-9.

2 Ibid. X 31-35.

3 Cf. O. Cullmann, The State in the Nezv Testament. New York, 1956, and in particular p. 72 , note 2.

${ }_{4}$ Cf. above: note 3. 
with blasphemous titles». St. Paul makes a similar statement in his letter to the Thessalonians ${ }^{1}$, where he speaks of the Rebel, Antichrist, who will raise himself above every divine name until he «claims that he is God».

Bede, in his Explanatio Apocalypsis, makes the following remark concerning the blasphemous titles: "For they call their kings gods, as well those who are dead, and, as it were, translated to heaven, as those also who have the name of Augustus on earth, which with them expresses deity ${ }^{2}$. These blasphemous titles may be looked at in various ways - in general, a Christian of the first century could regard as blasphemous all the honours offered to the emperors which: directly or indirectly, gave men the worship which should be reserved for God. More literally, the blasphemous titles could be those words addressed to an emperor as to a god.

An aspect of cult-worship which could have scandalized the Christians of Asia Minor and which was probably one of the reasons behind John's phrase concerning the 'blasphemous titles', was the use of such titles as 'Lord', 'Saviour' and 'God', attributed to the emperors by their well-wishers and flatterers. In addition to these titles, the acclamations which gradually developed as part of cultworship, and which were adapted for use in the Christian liturgy, will be considered as a sub-heading under this same point. Acclamations are rarely included in works dealing with the imperial cult and yet it is evident that they played an important role in keeping alive the people's awareness that their emperor was divine, or at least, potentially divine.

Imperial titles are identical with those titles which are applied by the Christians to Christ. It has been noted by various commentators that it would be too superficial to point out the similarities between the titles and to assume forthwith that the Christian usage was an adaptation of the pagan, and nothing more. Early critics often made such efforts to avoid any such 'superficiality' in their judgments that they failed to allow any possibility of influence in the use of these titles. There is obviously much that bears a strong resemblance, and there are many common traits between the emperor-cult and the

1 II. Thess. II 4.

2 Bede, Explan. Apoc. Lib. II. Chap. XIII: «Reges enim suos deos appellant, tam mortuos, et velut in coelum atque inter deos translatos, quam etiam in terris Augustos, quod est nomen (ut volunt) deitatis.» 
worship given to the Christian God through Christ ${ }^{1}$. There is no doubt that there are definite similarities in the vocabulary used in cult worship for the emperor and that used by the followers of Christ. Many of the Christian expressions have, it is true, their roots in Jewish terminology, but the pagan invocations must have been well-known to the first century converts.

\section{a) The Title 'Kv́oıs' in Imperial and Christian Usage}

Occasionally there are phrases in the Apocalypse which strike us forcibly as protests against a situation or a gesture. One of these comes in the form of a prayer: "You are Our Lord and God, you are worthy of glory and honour and power, because you made all the universe and it was only by your will that everything was made and exists ${ }^{2}$. It is possible that there is a deliberate stress in these words on the worthiness of the 'one Lord and God' as opposed to the cult-worship which similar terms offered to the pagan gods, rulers and emperors ${ }^{3}$.

There are a number of different implications behind the title 'Lord' ${ }^{4}$ but a sense of the divine must not be excluded from all

1 L. Cerfaux \& J. Tondriau, Le culte des souverains, 1957, cf. in particular the section entitled Comparaison avec le Judaisme et le Christianisme, pp. 441-456.

2 Apoc. IV 11. Cf. H. Richards, Key to the Apocalypse of John. London, 1967, pp. 57-58.

3 W. H. Roscher, Lexikon der griechischen und römischen Mytbologie. Leipzig, $1890-1897$, II 1 1755-1769, gives lists of gods and goddesses to whom the titles 'xúplos' and 'xupía' were given.

${ }^{4}$ W. M. Ramsay, The Greek of the Early Church and the Pagan Ritual. ET X (1888-1889) pp. 208-209, has underlined a purely human point in this whole question of influences and meanings of titles: "When converts in Galatia and Asia spoke of 'the Lord', it would hardly be possible for them to divest themselves wholly of the ideas which they had formerly associated with the titles. " C. H. DoDD, The Bible and the Greeks. London, 1935, p. 9, gives the various meanings of this title: "'xúpıs' means a person in supreme authority, the head of the house, the master of slaves, etc. In the Hellenistic period, it is applied to absolute monarchs, who, though Greeks, ruled over Oriental Kingdoms. The title as applied to kings, appears in close connection with the Oriental, and especially Egyptian deification of the reigning monarch, and it is a question whether we are to give political or religious priority to the use of 'xúpıos'. 'Kúpıos' was occasionally applied to gods in classical Greece. This is distinct from its use as a divine title which first appears in Hellenistic Greece and in the East... The absolute use of ' $x$ úpros' in the Septuagint differs essentially from that used for a reigning king.» This author gives further details of this point in his book According to the Scriptures. London, 1952, pp. 120-121: «It has been widely held that the use of this title is 
the texts which apply to the emperors. The actual term 'Lord' was not blasphemous as such; the Eastern rulers had been called 'Lord' in the sense that their subjects were as slaves before them, but a special significance had been given in the Septuagint translation of the Bible, when the word 'Yahweh' had been replaced by 'Lord'. Some commentators are of the opinion that there is no divine sense in the pagan title of 'Lord', and from this, point out that there can be nothing in common between the titles of Christ and those applied to the emperor.

The source of the titles as applied to Christ, and to the emperors is not common; that I accept. But to say that «en réalité elles n'ont de commun que des mots ${ }^{1}$, is not supported by some early evidence. This is perhaps the root of the problem - while ' $x$ úproc' does not directly imply divinity, the divine emperor was called ' $x$ úpıs', and it is on this level that confusion could have been caused, irrespective of the source of the title, or the influences which affected its use.

The first emperors did not aspire to the title of 'Lord'. Augustus seems to have reacted strongly against the title, to judge from Suetonius' account, for he felt that the use of such a term was a reproach and ill-omen. On one occasion, the words « $\mathrm{O}$ good and gracious

due to the familiar use of ' $x$ úpıos' in pagan cults of the Hellenistic world, but it is not certain that the 'xúpros' of the LXX is a pure piece of Hellenization or that it was entirely without influence upon certain Hellenistic circles. There can be little doubt that various Hellenistic usages affected the development of the idea of Christ as 'xúpıos' in early Christian theology or even in the New Testament itself.» W. Foerster \& G. Quell, Lord. London, 1958, note the following: "In the imperial epoch, ' $x$ úplos' occurs as a brief summary of the emperor's position. There is no text in which ' $x$ úptos' applied to the Roman Emperor denotes by itself that the Emperor is a god" (p. 28). "In the Septuagint, the implication is that the bearer is sovereign in the absolute sense... The reason why God is the absolute Lord of this world and its course, and over the individual, is because $\mathrm{He}$ is the Creator of all» (p. 82). "In the New Testament, there are a number of secular usages, e. g. Lord and owner of a vineyard, of an ass, or of a dog; the master of a free steward or of unfree slaves. In the New Testament, the name of 'xúpıç' implies equality with God. The whole New Testament uses 'xúplos' as the resurrected Lord» (p. 97). "Paul makes no distinction between ' $\theta \varepsilon$ 's' and ' $x u$ 'plos' in the sense that 'xúplos' denotes a mediator-divinity" (p. 103). For other literature cf. S. Herner, Die Anvendung des Wortes Kúplos im Neuen Testament. Lund 1903. W. W. von BaUDIssin, Kyrios als Gottesname im Judentum und seine Stelle in der Religionsgescbichte. 4 vols Gießen, 1926. R. Bultmann, Theology of the New Testament. London, 1965, pp. 51-52.

1 K. Prümm, Herrscherkult und Neules Testament. Biblica 9 (1928), pp. 3-25; $129-142 ; 289-301$. On p. 301, this author speaks of the two formulae, ' $x$ úplos

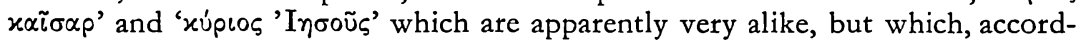
ing to Prümm, have nothing else in common. Cf. A. Deissmann, Light, p. 346. 
lord» were spoken during a play in the theatre which the audience applied to Augustus, who was also present. Far from welcoming such a title, the emperor quenched the general enthusiasm and the following day issued an edict, reproving his overzealous subjects. Realizing that this could easily degenerate into something more extravagant than a courtesy-title, Augustus forbade its use even in his own family, whether it be said in earnest or in fun ${ }^{1}$.

It is well-known that Tiberius was seemingly reticent about accepting honours especially if they tended towards the divine, and he behaved in the same way with regard to titles. Tacitus relates how Tiberius reacted unfavourably towards those who declared that his actions were divine, or who called him 'lord' 2 . In this particular case, the relation of the divine actions with the title of 'lord' indicates that there was a link between these two aspects of cult-worship, and implies that there was an element of the divine in this imperial title. Tiberius stressed the fact that he was a man like other men, and not some divine being ${ }^{3}$. He makes it perfectly clear that he understands another meaning in the title of 'Lord', at least in some contexts; he would not allow himself to be called 'master' by the freemen ${ }^{4}$ and made his view-point quite clear at the beginning of his reign. He would often declare "I am master of the slaves» ${ }^{5}$ as a

1 Suet. Aug. 53, 1-2: «Domini appellationem ut maledictum et obprobrium semper exhorruit. Cum spectante eo ludos pronuntiatum esset in mimo: O dominum aequum et bonum $!$ et universi quasi de ipso dictum exultantes comprobassent, et statim manu vultuque indecoras adulationes repressit et insequenti die gravissimo corripuit edicto, dominumque se posthac appellari ne a liberis quidem aut nepotibus suis vel serio vel ioco passus est atque eius modi blanditias etiam inter ipsos prohibuit. Cf. W. Deonna, La légende d'Octave-Auguste. RHR 83 (1921), p. 43.

2 TAC. Ann. II 87, 2: «Neque tamen ob ea parentis patriae delatum et antea vocabulum adsumpsit, acerbeque increpuit eos qui divinas occupationes ipsumque dominum dixerant.»

3 Ibid. IV 38,1: «Ego me, Patres conscripti, mortalem esse et hominum officia fungi...»

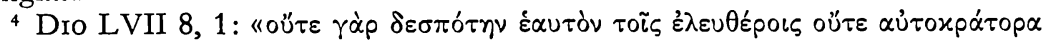
... $\varkappa \alpha \lambda \varepsilon \tilde{\nu} \nu$ हे $\varphi(\varepsilon \iota)$

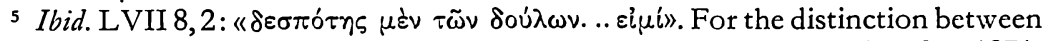

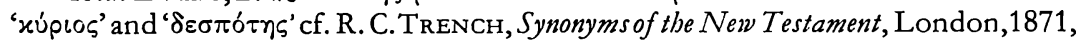
pp. 90-93: «A man was ' $\delta \varepsilon \sigma \pi o ́ \tau \eta s^{\prime}$ to his slaves, but ' $x u ́ p ı \varsigma^{\prime}$ ' to his wife and children, but this distinction was not observed by non-grammarian writers»; G. DaLman, The Words of Jesus. Edinburgh, 1902, p. 330, remarks how the title 'ó xúplos' becomes common enough despite the refusals of both Augustus and Tiberius, and that it was "associated with the divine honours paid even to living emperors». A. J. Festugière, "Kúplos» RSPhT 23 (1934), p. 362 (Notules d’Exégèse) gives 
reminder that it was in this sense alone that the term ' $\delta \varepsilon \sigma \pi 0 \tau \dot{\prime} \varsigma^{\prime}$ ' was acceptable to him and thus any divine allusions would have been ruled out. That Tiberius was referring to a divine sense is made clear from this reference, coupled with what we know of his attitude towards other divine honours which were offered to him.

The first emperors did not aspire to the 'divine' which could be understood in the title of 'lord', and it has been argued that the emperor was called ' $x$ úproc' as a mark of his political power and that it had no religious overtones ${ }^{1}$. O. Cullmann has seen that it would be artificial to attempt to keep the political sense apart from the man himself who received the title, if he were, at the same time, regarded as a divine being. Tertullian certainly seems to have recognized the strong possibility of lapsing from the political, and therefore in Christian eyes, legitimate meaning, and putting into the title of 'xúpıs' a deeper religious sense which would be contrary to the Christian idea of true worship. Tertullian declares that he would feel quite at ease in giving the title 'lord' to the emperor, so long as a difference is maintained in the sense, and that he is not forced to call the emperor 'lord' in the same sense as he calls his God ${ }^{2}$. For this author, there is only one 'lord' in the religious sense, and he is the eternal and omnipotent God, who is the master of the emperor himself. The Apocalypse is the forerunner of Tertullian's writings on this matter, for there is a reference to the 'Lord' which fits into the same context ${ }^{3}$. John describes how the ten horns, which represent

another interpretation: "L'attribution du titre aux empereurs n'aurait donc pas valeur d'apothéose. Les choses du moins se passeraient ainsi jusqu'à Néron.» But, referring to the text of Tacitus ( $A n n$. II 87,2) where Tiberius severely rebukes those who speak of him as 'dominus', Festugière adds: «Dans la pensée des flatteurs, dans celle de Tibère, 'dominus' se dit d'un dieu.» ThDNT p. 1045: "'xúplos' is one who can dispose of something or someone, ' $\delta \varepsilon \sigma \pi \delta \tau \eta s^{\prime}$ the one who owns something or someone.»

1 O. Cullmann, The Christology of the New Testament. London, 1963, p.196, points out that there is necessarily a connection between the secular and the religious use of the word. He adds: "When on one hand, the emperor was called Kyrios as a sign of his political power and, on the other hand, was revered as divine, the title Kyrios must automatically take on a religious significance.»

2 Tertullian, Apologeticus 34,2: "Augustus, imperii formator, ne dominum quidem dici se volebat; et hoc enim dei est cognomen. Dicam plane imperatorem dominum, sed more communi, sed quando non cogor, ut dominum dei vice dicam. Ceterum liber sum illi. Dominus enim meus unus est Deus omnipotens, aeternus, idem qui et ipsius.»

3 Apoc. XVII 12-14: "The ten horns are ten kings who have not yet been given their royal power but will have royal authority only for a single hour and in 
ten kings, have given over their authority to the beast, and having made war on the Lamb, they will be conquered, for he is the «Lord of lords and the King of kings."

Domitian was the first emperor who insisted on receiving the title of 'lord' officially, and he obviously took pleasure in the acclamations of 'lord' which were paid to him on public occasions, as, for instance, those which were paid to him on a public feast-day in the amphitheatre: "Happiness to the Lord and his mistress» ${ }^{1}$. Inasmuch as Domitian insisted on being regarded as divine, the word 'lord' would inevitably hold a secondary implication of the divine. Domitian took a tremendous pride in the titles of 'lord' and 'god', and this phrase follows immediately after the remark that he insisted on being looked on as a god ${ }^{2}$. This is as early as $85 \mathrm{~A}$. D., so these titles must have been in wide use by the end of Domitian's reign. Not only were they used in acclamations, but they came to form part of the official introduction of written documents.

Suetonius backs up Dio's statement by affirming that he started dictating a circular letter in the name of his agents with the following words: "Our Lord and God orders the following..." ${ }^{3}$

Tertullian states categorically that one should not give the title of God to emperors, since it can only be "the most pernicious flattery ${ }^{4}$. This would apply also to those titles which, though not divine in themselves, would in a certain sense acquire a divine meaning when applied to a divine emperor. A good example of this flattery took place in 91 A. D., after a conspiracy against the emperor had been discovered. Juventius Celsus was one of the men

association with the beast. They are all of one mind in putting their strength and their powers at the beast's disposal, and they will go to war against the Lamb; but the Lamb is the Lord of lords and the King of kings, and he will defeat them and they will be defeated by his followers..."

1 SuEt. Dom. 13,2: "Adclamari etiam in amphitheatro epuli die libenter audiit: Domino et dominae feliciter.

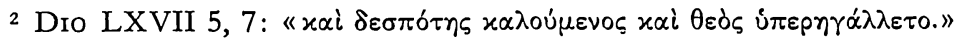

3 Suet. Dom. 13,4: "Pari arrogantia, cum procuratorum suorum nomine formalem dictaret epistulam, sic coepit: 'Dominus et deus noster hoc fieri iubet'.» Cf. A. Fincke, De appellationibus Caesarum bonorificis et adulatoriis usque ad Hadriani aetatem apud scriptores Romanos obviis. 1867, nos. 28 and 31. H. LiNSSEN, ' $\Theta$ còs $\Sigma \omega \tau \eta \dot{\eta} \varrho^{\prime}$ JLW 8 (1928), p. 65.

4 Tert. Apol. 34,3: "Tanto abest, ut imperator deus debeat dici, quod non potest (credi), non modo turpissima sed et perniciosa adulatione... Esto religiosus in Deum, qui vis illum propitium imperatori. Desine alium deum credere atque ita et hunc deum dicere, cui Deo opus est.» 
who had been implicated, but he managed to save his life by using this flattery spoken of by Tertullian. He begged a private audience with the emperor, and, this granted, he did obeisance before Domitian, and repeatedly called him 'master' and 'god'. Having thus gained the good-will of the emperor, he offered himself as an informant if his life should be spared ${ }^{1}$. This was granted to Celsus, although he managed to get by without informing on anyone until the death of Domitian.

It is exceedingly difficult to form precise and conclusive opinions as to the Christian attitude towards such titles; even, surprisingly enough, to the title of 'god'. One would imagine that this title would have caused tremendous heart searching among Christians, but, as with the other titles attributed both to Christ and to the emperors, it appears to have had an honorary-but-not-divine meaning which was recognized as such by the Christians and not considered as blasphemous. Tertullian speaks of its use merely as 'a bad omen', as if giving the emperor the title of god before his deification would bring him ill-luck. According to this author, it is a sign that one wishes the emperor ill if one calls him 'god' during his lifetime, since it is only after his death that he receives it officially ${ }^{2}$. Tertullian obviously believes that titles offered to a dead emperor do not hold the same significance as those given during his lifetime.

A fourth century writer, Aurelius Victor, has written a short account of the lives of the Caesars, and although he tends to exaggerate, particularly in the accounts of the tyrannous emperors, he nevertheless gives many details which correspond to those given by earlier historians. He describes Domitian's demand that he should be addressed as 'lord and god', a title which his immediate successors did not allow, although other emperors returned to this custom in later years ${ }^{3}$. Although under Domitian this title came to be used officially, there are many examples of its use for earlier emperors ${ }^{4}$.

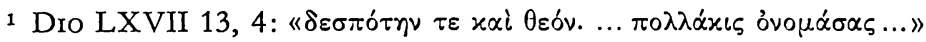

2 Tert. Apol. 34,4: "Maledictum est ante apotheosin deum Caesarem nuncupare. Scito te isto nomine male velle et male abominari, ut, vivente adhuc imperatore, deum appelles, quod nomen illi mortuo accedit.»

${ }^{3}$ Aurelius Victor, De Caesaribus XI 2 (ed. Fr. Pichlmayr, Leipzig, 1961): "Quippe qui se dominum deumque dici coegerit: quod, confestim ab insequentibus remotum, validius multo posthac deinceps retulere.»

4 Cf. A. Deissmann, Light, pp. 357-358. 
Aurelius Victor mentions an earlier emperor who attempted to take the title of lord, and this was none other than Caligula ${ }^{1}$. Proud of his previous exploits, he not only tried to take this title, but he endeavoured to put the royal crown on his head. It is probable that Caligula was not seeking to be called lord in the merely temporal sense, especially if we bear in mind his extreme desire for extraordinary honours. Whether or not these two bids for additional honours, that is, the kingship and the title of 'lord', were connected, it is certainly difficult to judge from the context alone, but the possibility is there that they do form part of the same aspiration, and that the political sense of 'lord' would not be entirely absent from the emperor's mind, either.

The title 'lord' gradually gained its acceptance as one of the titles of the emperor and from the time of Nero it found increasing popularity. Even under Claudius, there are a number of examples of its use; from the year $49 \mathrm{~A}$. D. there is the report of a lawsuit relating to the identity of a child in which Claudius is referred to as ' $x u$ pros' ${ }^{2}$. Similarly, an ostrakon in the Berlin Museum, inscribed in Greek, speaks of Claudius as Autokrator and Kyrios ${ }^{3}$.

The words of the procurator of Judaea, Festus, give an insight into the everyday use of the title by a Roman official when speaking about his emperor ${ }^{4}$. During Paul's captivity at Caesarea, Herod Agrippa and Berenice arrived to pay their respects to the procurator, Festus, who was vainly trying to find a solution to the problem of the accusations made against Paul. Festus invited his guests to hear Paul in the audience-chamber, and there he explained his own position in the case. He declared that as far as he could judge, Paul had committed no capital crime, and he realized that the whole affair was pointless because he had nothing definite to write to 'his Lord', that is to say, to the emperor. Festus' listeners seem to have understood

1 Aur. Vict. De Caes. III 13: "His elatus, dominum dici atque insigne regni nectere capiti tentaverat.»

2 Oxyrbynchus Papyri I. xxxvir 1, 6, ed. B. Grenfell and A. Hunt. London,

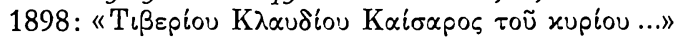

3 U. Wilcken, Griechische Ostraka. Leipzig \& Berlin, 1899, p. 268, no. 1038

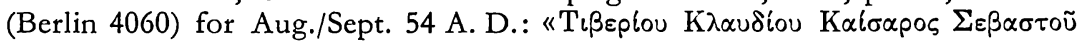

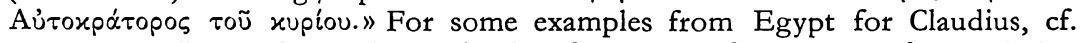
P. Bureth, Les titulatures impériales dans les papyrus, les ostraca et les inscriptions d'Egypte. Bruxelles, 1964, p. 30.

4 Acts XXV 25. 
who 'the Lord' was, without any further explanation; thus by about 60 A. D., reference to the emperor as 'lord' was quite usual and accepted in Roman circles at least. This is testified by the many Greek and Syrian inscriptions of the early empire ${ }^{1}$, and, as has already been noted, its application to a 'divine' person, whatever its original sense, must have coloured its meaning to a certain extent. With this in mind, it might be well to consider in more detail the Christian attitude by looking more closely at some of the texts.

An interesting account which underlines the political aspect of this title in a rather backhanded way, is the account given by Josephus, where he describes an incident in Alexandria in 73 A. D., which caused the death of a number of Jews ${ }^{2}$. A subversive movement had been started among the Jews in Alexandria by some members of the party of the Sicarii, who urged them to throw off the Roman yoke by declaring that God was their only master - "Deum vero solum dominum dicerent». The Sicarii murdered some who objected to this agitation, so the Romans took action, summoning the Jews to a meeting, during which about six hundred Sicarii were rounded up and handed over to the Romans. The Jewish attitude towards the emperor was apparently similar to the Christian, although it had less significance since there was not the same religious motive behind the action of the Sicarii, as later there would be for the Christians. Possibly the organizers of this movement among the Sicarii used the religious enthusiasm of the mob, who did not realize clearly the distinction between the political and the religious motives involved, and it is likely that many did, in fact, give their lives thinking that it was a question for them of accepting or refusing to worship the emperor. For we are told that the Sicarii were tortured in order to make them acknowledge Caesar as the 'lord' - «ut Caesarem dominum faterentur», but they remained steadfast, and refused to give in. Even young children were drawn into the affair, and the author remarks their constancy, for they did not allow themselves to be forced into acknowledging Caesar as the 'lord' - «nec enim vel eorum quisquam commotus est, ut dominum Caesarem nominaret».

1 Cf. A. D. Nock, Early Gentile Christianity and its Hellenistic Background. New York \& London, 1964, p. 32.

2 Josephus, Jewish War VII 407-419. The conflict here was political rather than religious, because the Jews were exempt from the obligations of imperial worship, but the Sicarii disguised their political intentions by stressing the religious. Cf. ThDNT III, p. 1058. 
The title of 'lord' for Vespasian must have been in general use at the time of the Sicarii; we get a clue from an ostrakon from about this time ${ }^{1}$. The continual everyday use of the title must have been widespread; the emperor was regularly called 'lord' when his name was used to give the date, and many examples of this may be found in Greek inscriptions on ostraka ${ }^{2}$.

A good example of the Christian attitude towards this title is found in the accounts of the Christian martyrs during the second half of the second century A. D. At the martyrdom of St. Polycarp, he was met by Herodes, the High Sheriff, and by Herodes' father, Nicetes. The Roman official voiced the question which must have been on the minds of many sincere non-Christians of the time: "What harm is there in saying, 'Caesar is the Lord', and offering incense, and thus saving your life?" ${ }^{3}$. In much the same way, the Scillitan Martyrs met their death in the year $180 \mathrm{~A}$. D. The words of the proconsul Saturninus resemble those of Festus, nearly 120 years previously, when he speaks of 'our Lord the Emperor'. He encouraged the prisoners to repent, saying that they might merit the indulgence of 'our Lord the Emperor' if they return to their right minds, that is, acknowledge the emperor as 'lord'. It is not merely a courtesytitle that is being discussed here, and both parties are aware of it the answer of Speratus, one of the Scillitan martyrs makes this quite clear. He declares: "I do not recognize the empire of this world... I recognize my Lord, the King of kings and Emperor of all peoples» ${ }^{4}$.

1 H. Windisch, Das Neue Testament im Lichte der neu gefundenen Inschriften, Papyri und Ostraka. Neue Jahrbücher für das klassische Altertum, Geschichte,

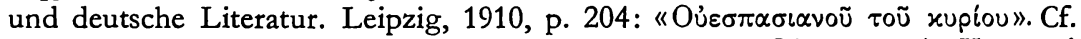

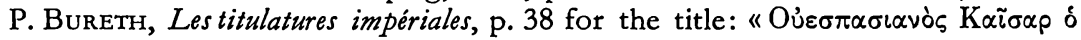
xúplos.»

2 P. Meyer, Griechische Texte aus Agypten. Berlin, 1916: No. 17, 3, p. 137,

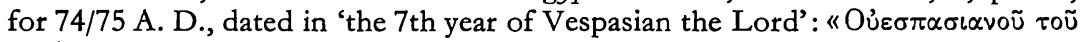
xuplou». No. 18, 3, p. 137, for the year 77/8, 'in the 10th year of Vespasian the Lord'. Similarly, no. 59, 9, p. $179 / 80$, no. 86 , p. 204 (75 A. D.), no. 87, p. 205

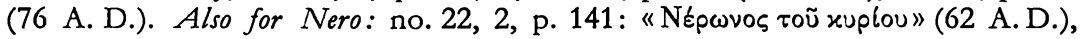
no. 23, 3 p. 142,(62 A. D.), no. 24, 2, p. 143 (63 A. D.), no. 25, 2 p. 143 (68 A. D.), no. 36a, 3 p. 156 (62 A. D.), no. 37, 3, p. 156 (67 A. D.,) no. 76, 4, p. 198 (68 A.D.).

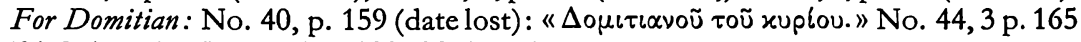
(91/2 A. D.). No. 77, 4 p. 199 (92 A. D.).

${ }^{3}$ Martyrdom of Polycarp: cf. P. Th. Camelot, Sources Chrétiennes, 10, Paris, $1969^{4}$, p. $220 \mathrm{ff}$.

4 E.C. E. Owen, Some Authentic Acts of the Early Martyrs. London, 1927, pp. 71-73, The Scillitan Saints, A. D. 180: «Saturninus proconsul dixit: Potestis 
In the Acts of the Martyrs, there is a definite contrast between the 'lords of the world' and Christ, and there are several New Testament texts which already seem to contrast the position of Christ with the generally-accepted 'lords' in the imperial setting. 'Lord of the world' as an imperial title was used as early as Nero ${ }^{1}$. Nock questions whether there was in the use of 'kyrios' "any conscious contrast between Jesus and the emperor», for there seems to be a veiled consciousness in the New Testament which becomes more apparent in times of persecution ${ }^{2}$.

When applied to Christ, the title takes on an additional sense in much the same way as the Christian use of ' $\sigma \omega \tau$ 'n ', when used for God, or for Christ (in the divine sense). This meaning is used in particular in the Apocalypse, where reference is made to the 'Lord of time' ${ }^{3}$. This is a sense which is never implied in any way for the emperors - it is an idea of lordship which is reserved solely for God. In the Apocalypse, Christ is not only the 'Lord of time' but also the Lord of death and of the underworld ${ }^{4}$. The same sentiments are found in the second chapter and again at the end of the Apocalypse, and although the actual word ' $x$ úpros' is not used, the meaning would have been obvious, since the apocalyptic style veiled many such truths which were well-known to its readers. As applied directly to God, two references are noteworthy; the first is the prayer of worship of the twenty-four elders who prostrated themselves in adoration before the throne of «the One who lives for ever and ever» ${ }^{5}$. This idea of the eternity of God is obviously in the mind of John as he gives the prayer of the elders: "You are our Lord and God». In Chapter XI, there is much the same scene - the twentyfour elders are enthroned in the presence of God. Prostrating themselves in profound worship, they pray to the Lord Who Is, and Who Was, an expression which conveys the mystery of the timeless-

indulgentiam domni nostri imperatoris promereri, si ad bonam mentem redeatis. » «... Speratus dixit: Ego imperium huius seculi non cognosco... quia cognosco domnum meum, regem regum, et imperatorem omnium gentium. " As O. CullmanN, Christology, p. 220 reminds us, "the idea of the lordship of Jesus... becomes especially concrete in opposition to Emperor-worship.»

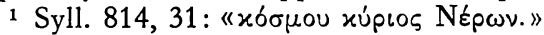

2 Nock, Early Gentile Christianity, p. 33.

3 M. Rissr, Zeit und Gescbicbte in der Offenbarung Jobannes. Basel, 1952, p. 57.

4 Apoc. I 17.

5 Ibid. IV 10-11. 
ness of God, who alone is worthy to be known as the Lord of Time: "We give thanks to you, Almighty Lord God, He-Is and He-Was, for using your great power and beginning your reign» ${ }^{1}$.

In St. Paul's writings, there is a stress on the divine character of the title 'kyrios' - «every tongue should acclaim Jesus Christ as Lord, to the glory of God the Father", he writes to the Philippians ${ }^{2}$, which seems an awareness of the existence of the 'pagan lords', who accepted divine honours directly in their person. We find a similar reference in the Epistle of St. Jude ${ }^{3}$, who gives a warning about 'certain people' who have gradually infiltrated among the Christians. They have been condemned because of their denial of all religion and for having rejected "our only Master and Lord, Jesus Christ». The examples of the use of the title 'Lord' in the New Testament are too numerous to mention in detail but those mentioned throw light on the Christian attitude towards such titles. St. Paul is obviously a man of his time and he knew the background of the people to whom he was writing. To the Corinthians, he speaks of the beings called 'gods' either in the sky or on earth, where, he adds drily, there appear to be plenty of gods and lords. However, for Christians, there is one God, the Father, and one Lord, Jesus Christ ${ }^{4}$.

It is not difficult to see the profound depth of meaning in the use of 'Lord' in this context; it is far beyond the profane use of the title as applied to emperors. It held a spiritual meaning not easily perceived except by those whose contemplation of God had enabled them to realize more clearly the attributes of their God.

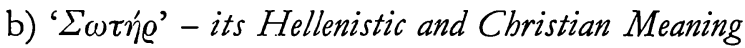

Another title which could well have appeared blasphemous to the author of the Apocalypse, was that of Saviour, applied to the emperors as it had been applied to the Hellenistic rulers before them. The

1 Ibid. XI 17.

2 Phil. II 10-11. Cf. Jn. XX 28: Thomas' profession of faith. Both are clear indications of the divine character of this title.

3 Jude 4.

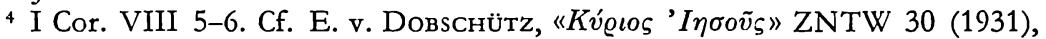
pp. 121-123, who gives three tables giving references to ' $x$ 'úpı' in the Old and New Testament, and various titles including the 'xúplos'. Also, L. KoeHLer, Christus im Alten und im Neuen Testament. ThZ 9 (1953), pp. 244-245. F. Hahn, The Titles of Jesus in Cbristology. London, 1969 gives very full bibliographical notes, pp. 114-135. 
Greek title was originally given to the gods, in particular to Zeus, Apollo and Asclepius ${ }^{1}$. Gradually the difference between the gods and men diminished until the divine title came to be applied to those men who, by their extraordinary deeds, had won for themselves the superhuman renown of being a Saviour of the people ${ }^{2}$. In the Hellenistic world, a man might receive this title if he had saved the people in some material way, either in the sense of having saved from ill-health, or in saving a city or a group of people from a calamity in some form.

Literary references to a man receiving this title during the Classical and Hellenistic periods are extremely frequent, and the meaning was no longer necessarily divine, but, as Dionysius of Halicarnassus puts it, it is a "laudatory name that men bestow in recognition of noble actions» ${ }^{3}$.

The title has also a sense of "preserver» and, in some contexts, the word ' $\sigma \omega \tau$ ' ' $^{\prime}$ ' is best translated and understood in this way. The above-mentioned author tells of Tarquinius, who accuses his father-

1 H. A. A. Kennedy, Apostolic Preaching and Emperor Worship. The Expositor, April, 1909, defines a $\sigma \omega \tau \eta$ ' 'as "the helper in time of need, the bringer of deliverance and salvation." As most authors dealing with this topic, Kennedy remarks the development from a title reserved for the gods to one applicable to heroic men and to rules like the Seleucids, Ptolemies etc. A. D. Nock, Early Gent. Christianity, pp. 35-44, adds the popularity of this title in Egypt for Isis and Serapis. M. P. Nilsson, Geschichte der griechischen Religion. Vol. II. Munich, 1950, p. 184f. notes that Athena Soteira is common in Attica. For the general views about this title cf. P. WendLAND, ' $\Sigma \Omega T H P$ ', ZNTW V (1904), pp. 335-353, in particular p. 336. W. Staerck, Soter I. Beiträge zur Förderung christlicher Theologie. 2nd Series. Vol. 31 (1933). E. B. Allo, Les dieux sauveurs du paganisme grécoromain. RSPhT 15 (1926), pp. 5-34. H. HaERENS, ' $\Sigma \omega \tau \eta \dot{\eta} \varrho$ et $\Sigma \omega \tau \eta \varrho i ́ a '$. Studia Hellenistica V (1948) pp. 57-68. This author also considers briefly the title of ' $\sigma \omega \tau \eta \dot{p} \rho^{\prime}$ as an attribute of the gods in the mystery-cults, and as bringing ' $\sigma \omega \tau \eta p i \alpha$ ' to those initiated in the cults. This article underlines the importance of the words ' $\sigma \omega \tau$ inp' and ' $\sigma \omega \tau$ inpla' with the sense of 'conservator' and 'conservation'. O. Cullmann, The Christology of the New Testament, London, 1963, pp. 239-240. R. Bultmann, Theology of N. T. p. 79. Lexikon der Alten Welt, p. 2842. Cf. Kittel, ThWNT. Stuttgart, 1964, vol. 7. p. 1006, in the section "Götter als $\sigma \omega \tau \tilde{\eta} p \varepsilon \varsigma »$. This volume containing references to " $\Sigma \omega \tau \dot{\eta} \rho$ " is not available in the English translation; in the German edition, a bibliography up to 1961 is given on pp. 1004-5.

2 P. Wendland, ' $\Sigma \Omega T H P$ ' p. 338: «Es kommt die Zeit, wo die Grenzen des Göttlichen und Menschlichen verschwinden, wo die Götter verblaßt oder vermenschlicht, die Menschen vergöttlicht werden.» Kittel, op. cit. "Menschen als $\sigma \omega \tau \tilde{n} \rho \varepsilon \varsigma$, pp. 1007-9.

3 Dionysius of Halicarnassus, Roman Antiquities IV 32, 1. 
in-law, Tullius, of having kept his grandfather's estate from him, although it was his due, as well as the kingship. Tarquinius points out that had his father-in-law acted justly, he would have been recognized as such, and, sharing the rule, he would have received honours and titles such as Benefactor, Father and Preserver ${ }^{1}$.

Plutarch tells of extravagant honours which the people of Athens paid to Demetrius, son of Antigonus in 307 B. C., after he had proclaimed Athenian liberty and declared that he had been sent by his father to restore the laws and ancient form of government, and to expel the existing garrison. At this, the people hailed Demetrius as their Saviour and their Benefactor ${ }^{2}$. Plutarch is disgusted that the Athenians should stoop so low as to call Demetrius and Antigonus 'Saviour-gods', for each year a priest of the Saviour-gods was elected. Diodor adds yet another detail directly connected with the title of Saviour - he tells of an altar which was consecrated to them and called the altar of the Saviours ${ }^{3}$.

Many other extravagant honours were voted to Antigonus and Demetrius - golden statues of them were set up by the Athenians,

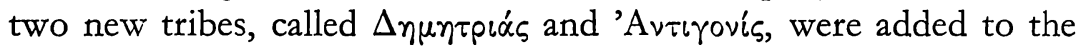
existing ten, and their portraits were woven into the sacred peplos of Athena, along with those of the gods. These honours, along with the annual games with procession and sacrifice in their honour, give an idea of the importance attached to the conferring of the title of 'Saviour'; had it been thought lightly of, it would not have been listed with those extreme honours which made Demetrius 'odious and obnoxious', at least in Plutarch's eyes.

Another typical example of one who was considered worthy to receive such a title as early as the fifth century B. C., was L. Siccius Dentatus. During the war between the Romans and the Aequians, Siccius and his men took an enemy camp which had been left unguarded, and went on to a victorious encounter against their enemies. Siccius, who, we are told, "slew the greatest number of the enemy and performed the most brilliant deeds", was acclaimed by his

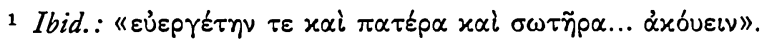

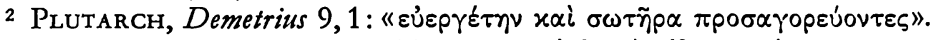

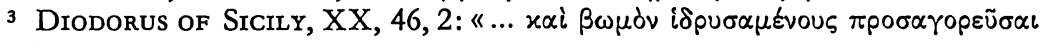

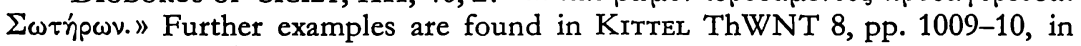
section d): ' $\sigma \omega \tau \dot{\eta} \rho$ ' im hellenistischen Herrscherkult. 
enthusiasic soldiers as "their father, their preserver and their $\operatorname{god} »^{1}$.

Plutarch gives various examples of the conferring of the title of 'saviour' on men who had merited it by deeds which safeguarded the general prosperity of the people. Titus Flamininus restored freedom to the Greeks in 196 B. C., which was proclaimed during the Isthmian Games. This proclamation was received with delirious joy by those attending the Games, and, forgetting the competing athletes, all sought to greet and acclaim Flamininus as «the Saviour and champion of Greece» ${ }^{2}$.

Camillus likewise received the title of «Saviour, father and god» in a curious incident during the invasion of the territory of the Faliscans by the Romans. The Falerii being besieged, a teacher attempted to betray his fellow-countrymen by leading the boys into the Roman outposts. Camillus did not take advantage of the traitor's cowardly attempt to curry favour with the Romans, and the man was stripped and driven to the city by the boys. The boys understood that they owed their safety, and that of their fellow-townsmen, to the justice of the Roman general, and, for this reason, proclaimed Camillus «their Saviour, their father and their god» ${ }^{3}$.

Mithridates, in the war against the Romans, showed himself likewise of generous behaviour with regard to his prisoners; he gave them sufficient supplies for the journey, and sent them back to their own countries. As accounts of this generosity spread, embassies came to the king, inviting him to their lands, and hailing him as their 'god and Saviour' ${ }^{4}$. Appian makes references to the "reputation of clemency» which grew up about Mithridates among his enemies; three times this author mentions the good treatment which Mithridates saw fit to give his prisoners, although he does not mention that the ensuing popularity resulted in his receiving the title of ' $\sigma \omega \tau \eta^{\prime} \rho$ '.

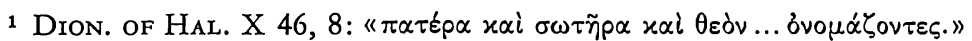

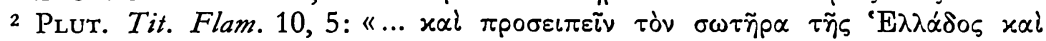
$\pi \rho \delta ́ \mu \alpha \chi 0 v . »$

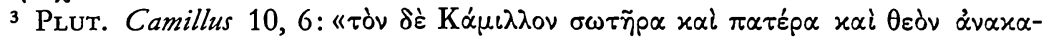

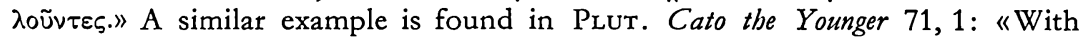
one voice they called Cato their Saviour and Benefactor, the only man who

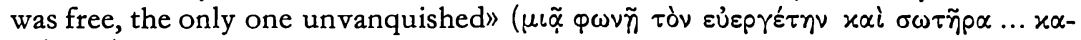
$\left.\lambda \circ u^{\prime} \tau \tau \omega \nu\right)$.

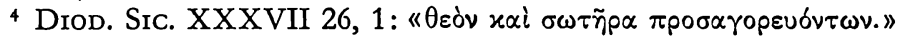


With such a tradition of use during the Hellenistic period, there was little likelihood of the title dying out as a title of honour during the Roman Empire. During the first century B. C., there is evidence of its use for Roman generals ${ }^{1}$; Julius Caesar was acclaimed «Saviour and Benefactor» by the citizens of Athens in 48 B. C. ${ }^{2}$.

The 'saving' had always been considered in a material way, in spite of the occasionally wide use of the term. Philo notes that Caligula had been looked on by many as the 'Saviour and Benefactor' of his people who would "pour fresh streams of blessing on Asia and Europe» ${ }^{3}$. These blessings would be the material benefits which a reign of peace would bring to the Roman Empire, just as the Golden Age of Augustus was the era of the Pax Augusta. During Caligula's illness, people began to fear that their previous hopes for peace would be brought to nothing should the emperor die; men discussed the possibility of the recurrence of the evils brought about by anarchy, evils which Philo lists with great feeling - famine, war, devastation, ravaging of fields, the loss of property, arrests and the desperate fear of slavery or death ${ }^{4}$. The title of 'Saviour and Benefactor' in this context underlines the individual and community aspect of the role of one who preserves or saves, as well as the material benefits derived from the direct or indirect activities of such a 'saviour'.

Since the reign of Augustus, 'Saviour' had been in frequent use for the emperors, especially in the East ${ }^{5}$ and its use continued steadily throughout the first century. It was not in itself a divine title, but, as has already been noted for the title of 'lord', in applying

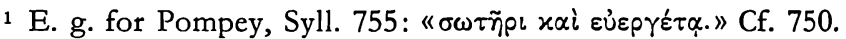

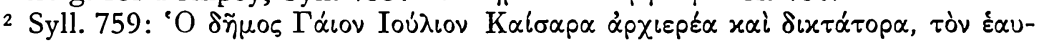

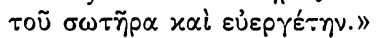

3 Philo, Legatio ad Gaium 4,1 (ed. E. Mary Smallwood. Leiden, 1961):

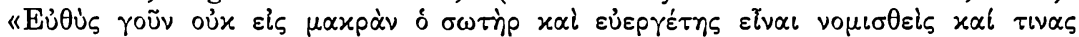

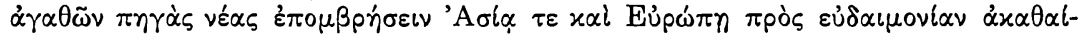

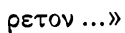

4 Ibid. 3, 16-17.

5 OGIS 458. An inscription from Priene tells how "providence has filled the Emperor with virtue in order to make a 'Saviour of humanity'.»Cf. J. Rouffiac, Recherches sur les caractères du grec dans le Nouveau Testament d'après les inscriptions de Priène. Paris, 1911. In particular pp. 78-79. The author underlines the importance of the fact that the official religion of the Empire used similar terms to those used in Christian worship, not because the former directly influenced the origin of these terms, but because of the 'influence par contraste'. 
it to a Divus, or to the living emperor, who was worshipped directly or indirectly through his Genius, it is most probable that this term gradually gained a 'divine' sense for the average man. As a title, it was not only given to emperors, but also to governors and officials, especially in Egypt.

A papyrus in the Gizeh Museum ${ }^{1}$ calls the Prefect 'his Preserver' in a petition connected with the son of a certain Saraeus. The letter is written by the husband of the nurse Saraeus, who had been caring for a foundling, put in her care by Syrus. After the death of the foundling, Syrus claims Saraeus' own son. The husband pleads with the prefect that justice should be done: "I therefore come to you, my Preserver, to obtain my rights... ${ }^{2}$.

There is also something of the Hellenistic notion of 'preserver' in Philo's descriptions of the blessings of Caligula's reign, mentioned above; calamities at the interior of the Roman Empire would be certainly more easily avoided if the unifying forces of the imperial 'figure-head' held men's loyalties against common enemies. With this in mind, I find it difficult to accept Fr. Bömer's statement that what the Hellenistic man would have called 'God and Saviour' became 'God and Father' for the Romans ${ }^{3}$.

During the Jewish campaign, Vespasian and Titus received enthusiastic acclamations and the people hailed them as their Saviours. At Tiberias, Vespasian and his army were met by the citizens, who opened up the gates of the city to him, and acclaimed him as their Saviour and Benefactor ${ }^{4}$. Much the same reception was reserved for Titus at Gischala in Galilee, for most of the citizens were anxious for an end to the war. Accordingly, Titus made an agreement with them, that their liberty would be granted to them if they surrendered on peaceful terms. The following day, when Titus arrived at the city, the gates were opened to him and the men, women and children flocked out to meet him, acclaiming him as one who had liberated their city ${ }^{5}$.

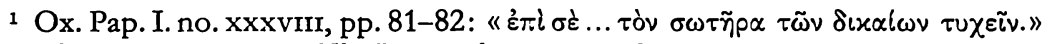

2 Cf. C. D. Morrison, The Powers that Be. London, 1960, p. 135.

3 Fr. Bömer, Tityrus und sein Gott. WJA IV (1949-50), p. 64.

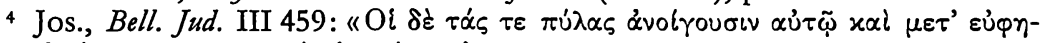

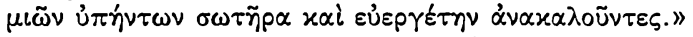

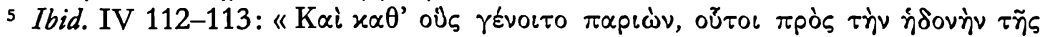

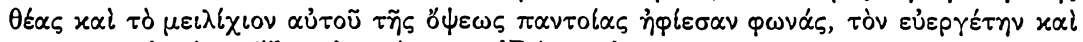

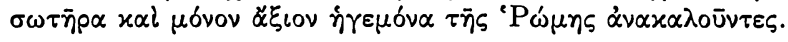


On the return of Vespasian to Rome after the siege of Jerusalem, he was received with great enthusiasm by the people who had come out to meet him, and they called him their Benefactor and Saviour, the only person worthy to be the ruler of the Romans ${ }^{1}$.

Over the years, scholars have put forward arguments for and against the theory that Christian titles and liturgical practices developed from those found in the ruler cult of the Hellenistic world. Whether or not the actual source of these terms is Hellenistic or Jewish has received great attention, but nevertheless there are obvious parallels between the imperial cult and early Christian worship, however superficial the similarities may be. To admit this in no way denies that the source of Christian terms and practices stem from the Jewish rather than the Hellenistic ${ }^{2}$; also, these parallels do not in themselves suppose any deep connection; in fact, in many instances such similarities tend to be quite superficial as far as the sense behind the terms is concerned. However, in the context of John's reference to 'blasphemous titles', it is not too far-fetched to suppose the attitude of ordinary folk towards such titles was influenced by their loyalties, and the meaning they understood in such titles. This attitude may be understood particularly well in the title of 'Saviour' ${ }^{3}$.

It has already been noted what the Greeks understood by the title of 'Saviour'; it is 'saving' or 'preserving' in a very material sense. In the Old Testament, there is quite another meaning where the stress is upon a 'spiritual saving', a deliverance from a state of sin, an atonement ${ }^{4}$. The term as applied to Christ has taken on this particular sense - Christ has delivered mankind from a spiritual

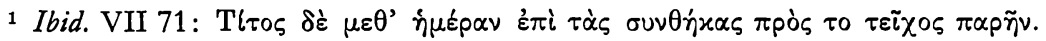

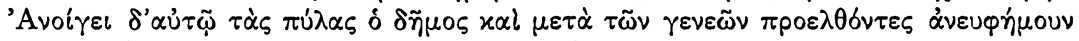

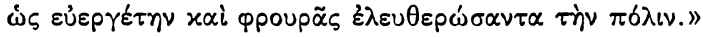

2 L. Koenler, Cbristus im Alten und im Neuen Testament. ThZ 9 (1953) p. 243, holds that the title $\sigma \omega \tau$ 'n $p$ is of purely Hellenistic origin. Cf. G. ThIEme, Die Inschriften von Magnesia am Mäander und das Neue Testament. Göttingen, 1906, pp. 3738.

3 A. Deissmann, Light, p. 368: "It would be possible in the case of many individual words belonging to the retinue of 'king' to prove the parallelism between the language of Christian worship and the formulae of the imperial law and the imperial cult... In the case of the word 'Saviour', the parallelism is particularly clear.»

4 A. Harnack, The Mission and Expansion of Christianity in the First Three Centuries (Trans. J. Moffatt) London, 1908, pp. 101-124. Chapter on the Gospel of the Saviour and of salvation. In particular, p. 101: "Jesus appeared among 
bondage, and when Christians speak of him as 'Saviour', this is how they understand the title. For this reason, Harnack's interpretation of the term for Christ is unnecessarily one-sided; he stresses above all the role of Christ as a healer, as a type of Christian Asclepius. It is true that Harnack sees Christ as the physician of body and soul, and in this sense, does indeed allow for the idea of atonement, but it would not be true to say that Christ is seen chiefly as a healer ${ }^{1}$.

The spiritual sense of the word ' $\sigma \omega \tau \eta$ 'p' when applied to God, and then to Christ, does not exclude the possibility of there being a material sense in the term also; Philo gives an example of this after the statue incident when, from a human point of view, there seemed little hope of human help. "All human aid vanishes; let it vanish. But let us hope in God our Saviour, who had many times saved his people from hopelessness and impossible situations... ${ }^{2}$. There is nothing here to suggest that Philo is merely thinking of spiritual situations - when applied to God, this title may have an additional meaning but it does not exclude the possibility of it retaining the material sense known in the Hellenistic world.

There are numerous references to Christ as 'Saviour' and it is a title which he received during his earthly mission as opposed to the title of 'Kyrios' which is applied only to the Risen Christ. Jesus is also referred to as 'Saviour of the World' and this particular form is strongly reminiscent of the equivalent in the imperial cult ${ }^{3}$. The first reference is made by the Samaritans at the town of Sichar, after Christ had spent two days with them and had led many to believe. Prior to his visit, the converted Samaritan woman was so full of conviction, that many came to believe because of all she had told them. After the visit, they told the woman that it was no longer because of her testimony that they were convinced, because now they had heard him for themselves and were totally convinced in their own minds that Christ was indeed the 'Saviour of the World' 4.

his people as a physician... a physician of soul and body." In the Mystery-cults there were numerous examples of the 'saving' aspect of religion, but there was no idea of redemption as such.

1 Cf. O. Cullmann, Christology, p. 242.

2 Philo, Leg. ad Gaium 29, 196.

3 Cf. O. Cullmann, Christology, p. 244.

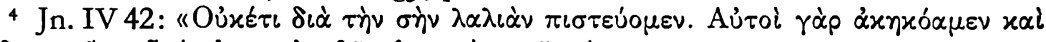

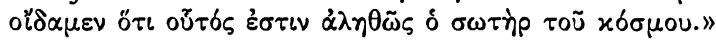


St. John again uses this phrase in his first Epistle ${ }^{1}$, when he declares that "we ourselves saw and we testify that the Father sent his Son as Saviour of the world». Deissmann has pointed out that

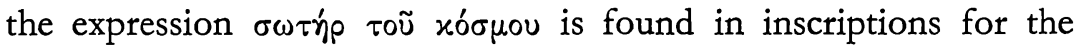
Hellenistic East in the first century for Caesar, Augustus, Claudius, Vespasian and Titus, so its imperial usage covered most of the century ${ }^{2}$.

The question has been raised why the appearance of the term for Christ is comparatively late, although it appears in the catholic and pastoral Epistles. One plausible reason for this delay is given by Taylor, when he offers as the most likely reason the fact that its use for the emperor, whether in a direct cult sense or not, would have made the first Christians reticent about using it too freely ${ }^{3}$. Another explanation may be the popularity of the term ' $x$ úpıs' which was sufficient in the early days of Christianity.

Even the question as to what extent the early Christians would have been influenced in the use of the title ' $\sigma \omega \tau$ 'n $\rho$ ' by its parallel usage in the imperial cult, is perhaps less significant than the fact that it was used at all, at least from the point of view of the Roman authorities. It was enough that it was used, and this aggravated the dispute between the authorities and the Christian community ${ }^{4}$.

\section{c) The Title of 'Divi Filius'}

A common title of the emperor which could have easily offended Christian ears was that of 'son of God'. In New Testament times, the term was popular for the emperors, as it had been for the Hellenistic rulers, and the Babylonian and Egyptian rulers before them. The title seems to have had a double sense in the empire; officially an emperor received it when his predecessor had been deified and

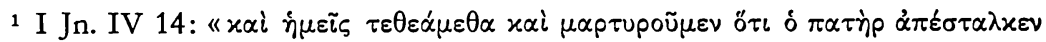

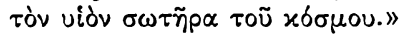

2 A. Deissmann, Light, pp. 368-369.

3 V. TAYLOR, The Names of Jesus. London, 1953, pp. 108-9: "... the use of the name in Greek religion and above all, in Caesar-worship, restricted and delayed its currency in the primitive tradition.»

${ }^{4}$ H. Kennedy, Apostolic Preaching and Emperor Worship, p. 298. 
his name had «been enrolled among the gods». There is also the indirect meaning which is stressed by some emperors more than others, and that is their divine sonship through miraculous means ${ }^{1}$.

With the deification of Caesar, Augustus had the right to take the title of Divi Filius, and this he did as early as $42 \mathrm{~B}$. C., which no doubt did a great deal to strengthen his position as he strove to establish his rule ${ }^{2}$. As has already been pointed out by various authors ${ }^{3}$,

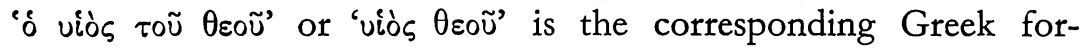
mula for this title. The title is extremely common on coins and in inscriptions; several examples picked at random will suffice to illustrate its use, as, for example, an inscription from 40 B. C. after the peace of Brundisium: "Imp. Caesar Divi f. (C. f.) III vir r. p. c. ovans quod pacem cum $\mathrm{M}$. Antonio fecit» ${ }^{4}$. On coins, this title only appeared in 38 B. C. ${ }^{5}$. Two other typical examples are found in an inscription from Olympia before 27 B. C. ${ }^{6}$, and on the base of a statue found in the theatre at Pergamum ${ }^{7}$. This latter inscription is a dedication made to Augustus during his lifetime and as such, is a clear example of the Eastern lack of reticence in addressing the emperor as a god even during his lifetime. Augustus is the son of god in virtue of the deification of his adopted father, Julius Caesar. At the same time, there must have been a special awareness in the use of this title that Augustus claimed a special relationship with Apollo, and the legend which grew up around his birth stresses this even more; Atia, the mother of Augustus was said to have conceived her son after a

1 The expression 'son of God' had a particular significance in Egypt where the Pharaoh was considered the descendant of the god $\mathrm{Ra}$, and this custom was certainly continued under the Ptolemies. Cf. G. Dalman, The Words of Jesus. Edinburgh, 1902, p. 272 f. Also, Fr. TAEgER, Charisma. Studien zur Geschicbte des antiken Herrscherkultes. II. Stuttgart, 1960, p. 98.

2 The assertion of Dalman that the term 'Divi Filius' was due merely to the modesty of Augustus is very limiting and negative; I should interpret it rather as a direct attempt to establish his rule on a legitimate basis, and as one of the many means of propaganda to influence the masses to his cause.

3 E. g. L. Cerfaux \& J. Tondriau, Culte des souverains, p. 449. A. Deissmann, Bible Studies, Edinburgh, 1901, pp. 166/7.

${ }^{4}$ CIL. I ${ }^{2}$ p. 180.

5 Cf. H. Heinen, Zur Begrïndung des römischen Kaiserkultes. Klio XI (1911) p. 140 , no. 2.

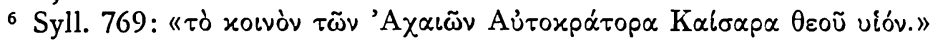

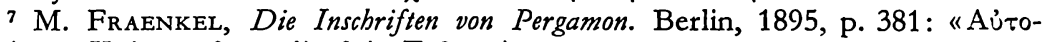

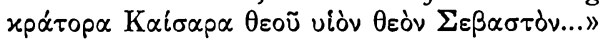


visit from Apollo in the form of a serpent. Augustus was born ten months later, and was reputed to be the son of Apollo ${ }^{1}$.

For Tiberius, it is more difficult to analyse his true feelings towards cult worship, but the traditional view is that he discouraged any honours which had not their roots in the reign of Augustus. However, Tiberius encouraged divine honours for Augustus, and in this way strengthened his own position; though he refused many honours and titles which were continually being offered to him, especially in the East, he nevertheless accepted and used the title 'Divi Augusti Filius' ${ }^{2}$.

As Augustus was the son of the god Julius, and Tiberius of Divus Augustus, so was Nero the son of Divus Claudius ${ }^{3}$, and Domitian the son of Divus Vespasian ${ }^{4}$. The frequency of the abbreviation of this title on coins and inscriptions must have impressed this idea firmly on the minds of Christian and pagan alike, especially as the title was not limited to the emperors alone.

There are many examples of the parallel use of this title in the New Testament for Christ ${ }^{5}$, especially in the Gospel of St. John, for this evangelist was particularly aware of the role of Christ as the Messiah. He declares that all he has recorded is there so that the reader may believe "that Jesus is the Christ, the Son of God, and that believing, you may have life through his Name» ${ }^{6}$. The title as used for Christ has its origin, no doubt, in the Old Testament usage, the principal source of which is thought to have been the second Psalm: «Let me proclaim Yahweh's decree, He has told me 'You are my

1 Suet. Aug. 94, 4. Cf. Dio XLV 2. This author maintains that Caesar was greatly influenced by Atia's account of her son's miraculous conception, and this was one of the reasons why Caesar intended to leave him as his successor.

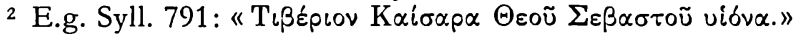

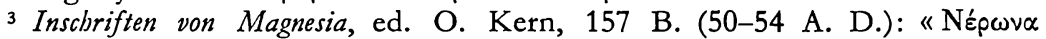

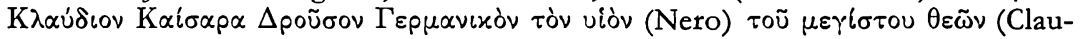
dius). Cf. G. Thieme, Inschriften v. Magnesia, p. 33. A. Derssmann, Light, p. 347.

${ }_{4}$ RA VI 16 (1940) p. 222: «Divi filius imp. Divi Vespasiani f. Domitiani. 1st January-13th September, 87 A. D.

5 R. H. Fuller, The Foundations of Nev Testament Cbristology. London, 1965, pp. 231-232: "Together with the Kyrios title, this designation was very popular in the Gentile Mission.» For other references e. g. Matt. IV 3, 6; XI 27; XIV 23; XVI 16; XXVII 39-44. Mk. I 1; III 11; V 7; IX 7; XII 6; XIII 32; XIV 61; XV 39. Lk. I 35; IV 3, 9; X 22. Jn. I 49; X 36; XX 31; Rom. I 4. Cf. Jerusalem Bible, London, 1966. Matt. 4. note. Cf. G. Dalman, Words of Jesus, pp. 274-287.

6 Jn. XX 31. Cf. V. TAYLOR, The Names of Jesus, p. 55. 
Son', today I have become your father. Ask and I will give you the nations for your heritage, the ends of the earth for your domain" ${ }^{1}$.

It is not likely that the term 'Son of God' for Christ had been influenced by the imperial use, nor even from the pre-imperial Hellenistic use or from the Mystery religions ${ }^{2}$. However, far from the Greek conception of 'son of God', the Christian title at least had the similarity of words, and this in itself could have led the Christians to look on the pagan use as blasphemous. For St. John especially, the title 'Son of God' for Christ had a particular significance. Christ himself speaks of God sending His Son into the world ${ }^{3}$. When the author of the Apocalypse refers to the blasphemous titles, it may well be that he had this title of Divi Filius in mind, for it had a special place in Johannine thought and expression.

\section{Acclamations - a Possible Interpretation of the Term 'Blasphemous 'Titles' as Used in the Apocalypse}

Having examined some of the terms common to both the emperor and Christ, which could possibly have influenced the author of the Apocalypse when he spoke of 'blasphemous titles', it would seem that these titles are not the only possible source for such a phrase. One aspect which is not generally included in commentaries of the Apocalypse dealing with this point is that of acclamations, and their possible influence on the minds of men, which was, no doubt, strong if temporary.

In the works treating the imperial cult, no mention is made of acclamations as a form of exteriorizing the sentiments of the mob, the soldiers or the Senate towards the emperor in his divine or potentially divine capacity. From a study of the acclamations, it would seem that though on the periphery of cult-worship, there was a definite connection with the more organized and established forms of worship, and that it would be of interest and utility to examine

1 Ps. II 7-8. For other Old Testament references: Ex. IV 22. Dt. I 31; XXXII 8 (angels); 10. Is. LXIII 15. Jb. I 6 (angels); Eccl. IV 11. Ps. LXXXII 6 (rulers and judges); LXXXIX 26, 27.

2 V. TAYLOR, The Names of Jesus, pp. 59-60.

3 Jn. III 17. 
more closely the use made both by the emperor and the people of these acclamations ${ }^{1}$.

I shall not go into a detailed study of the military acclamations, when a successful general was proclaimed 'imperator' on the battlefield by his victorious troops, neither shall I dwell overmuch on the 'adverse' acclamations, made in an attempt to force the hand of the emperor, and to oblige him to change some point of policy, or to show disapproval in general towards a regime.

There is always a natural tendency of the mob towards overexcitement which could lead to extravagant cries and shouts; at the same time, there is the seeming need of crowds to express their sentiments by chanting in unison, as we realize from our own experience of 'cause-marches' in contemporary times, or even the modern equivalent of the Roman circus, the present-day football match. The vatious books dealing with the psychology of the mob throw light on this aspect ${ }^{2}$.

Under the early emperors, with their general policies of restraint, there are few references to the acclamations of the people, and it is only under Nero that they seem to be accepted and even positively encouraged. With the development of the imperial cult, and as its possibilities as an integrating force were gradually perceived, the directing of such manifestations seems to have accordingly become more organized.

I now intend to examine the references to acclamations and to place them in their context in an attempt to ascertain how far one can support this theory that acclamations were part of the imperial cult, though of less importance than the established ritual. Acclama-

1 Cf. Th. Klauser, Reallexikon für Antike und Cbristentum, art. Akklamation, vol. I. Stuttgart, 1950, cols. 216-233, with bibliography. This author gives examples of acclamations in Iran, Israel, Asia Minor, Syria, Greece, Alexandria, Egypt and Byzantium.

2 L. FriedläNDER, Roman Life and Manners under the Early Empire. London, No date. The author gives an interesting chapter (I) on the spectacles during the early empire, and he compares them with the entertainments during the Republic. Friedländer stresses the lack of other occasions for public meetings and proclamations. R. MAcMullen, Enemies of the Roman Order. London, 1966. Cf. especially the chapter on urban unrest, and p. $170 \mathrm{ff}$. (with note 10 p. 339). MacMullen points out the «connection between the people as an audience and the people as an assembly in the constitutional sense - a connection made express in the use of theatres for mass meetings». The "political effectiveness of disorders $"$ is also discussed. 
tions were not, of course, made solely to emperors or state leaders; they were given to men who had captured the popular imagination in some way, and in these cases, they were marks of popularity or favour. There is an example of this given by Horace, where he describes the warm reception given to Maecenas in $30 \mathrm{~B}$. C. in the Theatre of Pompey, when he made his first appearance after a serious illness ${ }^{1}$. Horace mentions specifically that Maecenas was a knight ('eques'), perhaps to underline that he received these honours unofficially.

The acclamations accorded to Julius Caesar were certainly less restrained, indeed almost excessive. In fact, Suetonius gives the impression that they were 'unheard of' at the time. Returning from the 'sacrificium Latinarum', Caesar was hailed with immoderate acclamations. It is interesting to note that it was at this point that a man from the crowd placed a crown made from a branch of laurel on the head of Caesar's statue ${ }^{2}$. This last action is generally listed among the honours rendered to Caesar, and, linked as it is with the acclamations of the people, it would seem probable that there was a connection between the two, though Suetonius does not give the actual titles which were given, which could well have had divine overtones (for example, Juppiter Julius).

Augustus did not encourage any extreme professions on his behalf by the people; as we see from his reticence in other spheres of cult worship, he was anxious to avoid any exaggeration or excessive honours which could scandalise his Roman subjects. It is reasonable to suppose that Augustus saw such acclamations as a potential danger, for the mob was an element easily swayed and he had had experience of this phenomenon after the death of Caesar. Suetonius shows Augustus as acting very strictly in this matter, and there is little doubt that the first emperors made no efforts to channel the enthusiasm of the plebs, and, in fact, if Suetonius is to be taken at his word, they acted strongly against such behaviour. On one occasion, during a mime, the words «O good and just master» were spoken.

1 Horace, Carm. I 20, 3: «datus in theatro cum tibi plausus, care Maecenas eques, ut paterni fluminis ripae simul et iocosa redderet laudes tibi Vaticani montis imago.»

2 Suet. Jul. 79, 1-2: "Nam cum in sacrificio Latinarum, reuertente eo inter immodicas ac nouas populi acclamationes, quidam e turba statuae eius coronam lauream... imposuisset...» 
These words the over-enthusiastic spectators applied to Augustus, almost as an acclamation, and the emperor put an end to these extravagant praises and even rebuked the people in an edict on the following day ${ }^{1}$.

In 59 A. D., Nero established a special corps of about 5000 soldiers called 'Augustans' (Augustiani). These young men have been described as "of the upper classes, who were trained to join the emperor in gymnastic and artistic exhibitions ${ }^{2}$, in imitation of similar groups which had been formed during the Hellenistic period, for example, the " $\beta \alpha \sigma \iota \lambda \iota$ เкi $\pi \alpha \tilde{i} \delta \varepsilon \zeta_{.} »$ Dio, however, gives another detail about these Augustiani which seems significant in the development of the notion of the emperor's divinity ${ }^{3}$. He says that these soldiers were to lead the applause when Nero made an appearance in the theatre - the forerunners of our contemporary cheer-leaders in the Western world. These men would urge on the spectators, many of whom joined in the shouts of the Augustiani against their better judgment.

It is under Nero that the acclamations acquire a more specific cult-value, for the emperor is acclaimed in terms which are closely connected with the divine, and which underline the imperial claims to divinity just as much as a statue of an emperor with the attributes of Apollo, Mars or any other god. The acclamations led by the Augustiani certainly held some element of divine worship, whether or not they were made with all the sincerity supposed: "Our Apollo, our Augustus, another Pythian. By thyself we swear, O Caesar, none surpasses thee» ${ }^{4}$. Tacitus is certainly not convinced that these

1 Suet. Aug. 53, 2 (cf. p. 55): "Cum spectante eo ludos pronuntiatum esset in mimo: $\mathrm{O}$ dominum aequum et bonuml et uniuersi quasi de ipso dictum exultantes comprobassent, et statim manu uultuque indecoras adulationes repressit et insequenti die grauissimo corripuit edicto." Cf. Reallexikon für Antike und Christentum, vol. I, cols. 220-221, where mention is made of the acclamations to Germanicus by the people of Alexandria in A. D. 19. Cf. also U. Wilamowitz \& F. Zucker, Zwei Edikte des Germanicus. SbB 1911 pp. 794-821. E. Peterson, $\mathrm{E}_{\zeta} \Theta \varepsilon \delta \delta_{s}$, pp. $172 \mathrm{f}$. who gives the conclusions of C.Cichorius, Römische Studien, 1922, pp. $377 \mathrm{f}$.

2 A. Momigliano, CAH X p. 717. Cambridge, 1934. Cf. M. Rostovtzeff, Klio, Beiheft III, 1905, p. 74 ff. PAULY-Wissowa, RE II cols. 2363. J. GAGÉ, La Victoire impériale dans l'empire chrétien. RHPR (1933), p. 378.

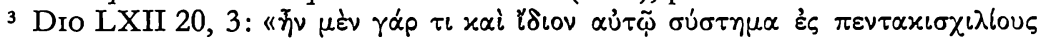

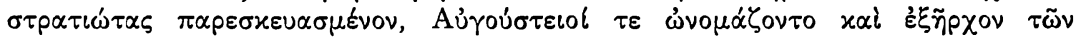
ह่ $\pi \alpha i ́ \omega \omega . »$

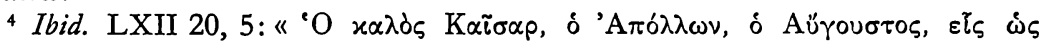

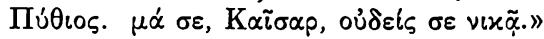


acclamations came straight from the heart. The plebs were accustomed to supporting the actors with their shouts and applause, and so Nero came in for his share. Having explained this much, Tacitus adds two words, full of significance: "Crederes laetari» ${ }^{\text {. One can }}$ sense the irony in these words: "one might suppose that they were full of joy", showing his scepticism as to whether such acclamations were the genuine exteriorization of the feelings of the spectators. Tacitus also mentions the formation of this band of Augustiani, all of whom were remarkable for their age and their strength, and this author gives the additional detail that they were Roman 'equites', drawn towards this new position either from a spirit of boldness or from the hope of attaining an influential position ${ }^{2}$. Day and night, the applause and acclamations of these young men echoed around the palace, using such extravagant terms while describing the beauty and the voice of the emperor, that they could have been applied to the gods ${ }^{3}$. Tacitus is obviously unsympathetic to such forms of worship, regarding all excessive praise as hypocrisy and as a tool in order to advance those who were willing to debase themselves by the very rendering of such acclamations.

Suetonius, on the other hand, is less specific about the grade of these young men, although he does state that they were adolescents from knightly families. He gives more details about the divisions of this 5000-strong corps; it was divided into factions, each of which was made responsible for a particular kind of applause, which would act as a background when Nero performed in the theatre - «bombos et imbrices et testas uocabant» ${ }^{4}$.

1 TAC. Ann. XVI 4, 4: "Et plebs quidem urbis, histrionum quoque gestus iuvare solita, personabat certis modis plausuque composito. Crederes laetari.»

2 TAC. Ann. XVI 15, 5: "Tuncque primum conscripti sunt equites Romani cognomento Augustianorum, aetate ac robore conspicui et pars ingenio procaces, alii in spem potentiae.»

3 Ibid.: "Ii dies ac noctes plausibus personare, formam principis vocemque deum vocabulis appellantes; quasi per virtutem clari honoratique agere.»

4 Suet. Nero 20, 6: «Neque eo segnius adulescentulos equestris ordinis et quinque amplius milia e plebe robustissimae iuventutis undique elegit, qui divisi in factiones plausuum genera condiscerent. " ' $\beta$ ó $\mu \beta \varsigma^{\prime}$ ' was a deep, hollow noise, a booming sound which might have been used to describe trumpets. An 'imbrex' was a hollow tile used in roofing, which would no doubt, serve admirably as 'clappers' to denote enthusiasm at the end of an entertainment, or else it could refer simply to a mode of applause with the hands, as is customary even today. A 'testa' was an earthen vessel, a brick or a tile or, less commonly, 
These Augustiani seem also to have been quite recognizable, both by their thick hair and by their ornate uniform and their refinement. They did not wear a ring on their left hand and their leaders earned as much as four hundred thousand sesterces ${ }^{1}$.

Another reason why I consider these acclamations as part of the developing imperial cult is because they are linked with such things as lights and incense, which definitely formed part of cult-worship ${ }^{2}$. On the return of Nero from Greece, his triumphal entry into Rome is described in detail by Dio; the crowns Nero had worn were carried in first, followed by men bearing wooden panels inscribed with the name of the games and the type of contest, as well as an inscription stating that "Nero Caesar, first of all the Romans from the beginning of the world» had won it ${ }^{3}$. Nero himself followed in the triumphal car wearing a gold-spangled cloak, and a garland of wild olive, and was accompanied by soldiers and knights and the Senate. The whole city had been decorated with garlands in honour of the 'victorious' emperor, lights added to the atmosphere of festivity, and the air was filled with incense. Incense was to hold an important place in cult ritual, and, in fact, at the beginning of the second century, it was one of the methods used to ascertain whether a man was sincere in denying his Christianity - he was obliged to pray to the gods, to blaspheme the name of Christ, and to sacrifice with incense and wine before the statue of the emperor ${ }^{4}$.

The acclamations themselves were more extravagant at this stage: «Hail, Olympian Victor! Hail, Pythian Victor! Augustus! Augustus! Hail to Nero, our Hercules! Hail to Nero, our Apollo! The only victor of the Grand Tour, the only one from the beginning of time!

a shell. Any of these things could have been used, though perhaps a tile would be the most likely, as it would be closely connected with the 'imbrex'.

1 Suet. Nero 20, 6: «... operamque navarent cantanti sibi, insignes pinguissima coma et excellentissimo cultu puris ac sine anulo laevis, quorum duces quadringena milia sestertia merebant."

2 Professor Othmar Perler reminded me of the fact that torches and incense are part of the ceremonial attached to the court of the Oriental sovereigns without necessarily having any cult significance.

3 Dio LXIII 20.

4 Pliny, Letters X 96, 5 (LCL. London, 1958): "Qui negabant se esse Christianos aut fuisse, cum praeeunte me deos appellarent et imagini tuae, quam propter hoc iusseram cum simulacris numinum adferri, ture ac vino supplicarent, praeterea maledicerent Christo, quorum nihil cogi posse dicuntur, qui sunt re vera Christiani, dimittendos esse putavi.» 
Augustus! Augustus! O Divine Voice! Blessed are they that hear you!» ${ }^{1}$. Some of these acclamations are honorific without specific reference to the emperor's divinity, but others, such as "Our Hercules», or "Our Apollo», or "O Divine Voice» are more than mere cries of welcome. Dio himself realized that his readers would find such praise excessive and unfitting, for he stresses that he had purposely used the very words of those making the acclamations; in fact, he adds several lines to excuse his having done so, for to have eliminated any expressions which might have given disedification to his readers, would have lessened the distinction of the whole work.

The parallel account given by Suetonius mentions specifically that the emperor's chariot was followed by his professional applauseleaders, who called out repeatedly: "We are the Augustiani and the soldiers of his triumph ${ }^{2}$. Although Dio's text does not mention the Augustiani, it is obvious from earlier evidence, even without the confirmation by Suetonius, that they were involved in the acclamations which were such an important part of the triumphal procession. Suetonius declares that all along the route of the procession victims were immolated, but he does not say who was the object of these sacrifices - the gods, as a thanksgiving for the safe and glorious return of the emperor, or the emperor himself.

Dio remarks with irony that not only did the mob in general witness, endure and approve Nero's extraordinary behaviour, but that the soldiers also joined in the acclamations ${ }^{3}$. Since this was in 67 A. D., during his Greek tour, the acclamations were connected with his 'successes' in the Games - he was called Pythian Victor, Olympian Victor, Victor in the Grand Tour and Universal Victor. None of these expressions in themselves bears any direct relation to cult-worship, but Dio adds that there were also the usual acclamations, as well as the titles belonging to his imperial status, so that the names of 'Caesar' and 'Augustus' were used frequently as well.

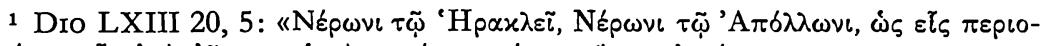

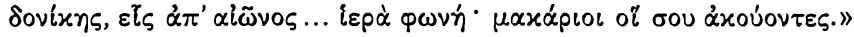

2 Suet. Nero 25, 1: «... sequentibus currum ovantium ritu plausoribus, 'Augustianos militesque se triumphi eius' clamitantibus.»

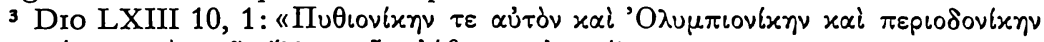

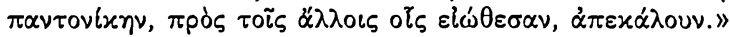


We have already seen that the very name of Augustus suggested a sacred element and the chanting in unison of one of the emperor's titles - and a most significant one for the people for it linked the emperor in a special way with Dirus Augustus - was, no doubt, an honour which Nero did all in his power to encourage.

In fact, in a similar circumstance, we are told explicitly that Nero 'organized' to some extent the praises that were lavished on him by the Alexandrian immigrants, who had arrived in Naples a short time previously ${ }^{1}$. The 'laudationes' which were sung or chanted in honour of the emperor, so pleased him that he gave orders for an even greater number of these immigrants, presumably to encourage the continuance of such hymns of praise. Here we see the emperor actively encouraging his own honours, which strengthens the theory that Nero used and organized the acclamations of the people for his own ends.

Josephus cites various occasions when the enthusiastic people showed their gratitude to their liberator by their united acclamations. He describes Vespasian's campaign against the citadel at Tiberias, for example, and as soon as Vespasian realized that the inhabitants were not hostile to his intentions, he advanced towards the city. At this point, the multitude opened the gates of the city, and met Vespasian with "acclamations of joy" calling him their Saviour and Benefactor ${ }^{2}$.

A similar episode took place at the surrender of Gischala in Galilee by which Titus had promised the inhabitants the recovery of their liberty.The people opened the gates of the city for him at his approach and came out with their wives and families, acclaiming Titus as their benefactor and the deliverer of their city ${ }^{3}$.

It is interesting to note that the third example of acclamations given by Josephus for this epoch, deals with those given by the people of Rome after the siege of Jerusalem. Perhaps this episode appealed to the popular imagination, for the acclamations were generous and varied; we are told that the people he passed made

1 Suet. Nero 20, 5: «captus autem modulatis Alexandrinorum laudationibus, qui de novo commeatu Neapolim confluxerant, plures Alexandria evocavit.»

2 Jos. Bell. Iud. III 459, see p. 68 note 4.

3 Ibid. IV 112-113, see p. 68 note 5. 
all sorts of acclamations, calling him their Saviour and Benefactor and the only person worthy to be the ruler of the city of Rome ${ }^{1}$.

All acclamations do not come under this group which has been linked with the divine honours given to the emperor. There were the acclamations of the soldiers which gave a man the position and rights of emperor; this obviously took place at the beginning of a reign only, as opposed to the popular acclamations which punctuated the emperor's public appearances, particularly in the theatre or circus. The rise of Otho gives a good illustration of this last point; as companion of Nero and the previous husband of Poppaea, he looked upon himself as a worthy successor of Galba. When Galba chose M. Piso Lucinianus as successor, he thus offended Otho, who had been the first commander to proclaim his allegiance to Galba, and he therefore made overtures to the praetorian guard, in the hope of gaining their allegiance. Suetonius tells how Otho was raised on the shoulders of the soldiers, where he was saluted as emperor, and he was then borne along, surrounded by soldiers who acclaimed him, sword in hand, and all who met him thus, joined forces with him ${ }^{2}$.

In his desire to please the mob, Otho accepted various honours which he later had to refuse when he realized that the most influential men were displeased by these practices. For example, the crowd acclaimed him in the theatre by the name of $\mathrm{Nero}^{3}$, and began producing statues of Nero in public. These actions were probably an attempt to legitimize Otho's claims for the imperial title, as much as anything else, and, as soon as Otho felt his position secure, he abandoned such practices.

Not all forms of acclamations can be looked on as part of cultworship - a brief mention has already been made to the 'adverse' acclamations made in the presence of unpopular emperors, and, apart from giving some examples, I shall not study them in detail since they do not relate directly to this idea of imperial honours. After the death of Ofonius Tigellinus, the prefect of the imperial guard, at the instigation of Otho, the mob pressed towards the

1 Ibid. VII 71, see p. 69 note 1.

2 SuEt. Otho 6,6: «... et a praesente comitatu imperator consalutatus inter faustas acclamationes strictosque gladios ad principia devenit, obvio quoque non aliter ac si conscius et particeps foret adhaerente.»

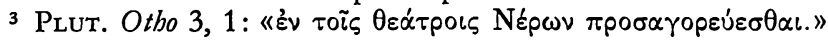


Palatium and in the public places, in the theatres and in the circus, the crowds raised their voices in seditious cries ${ }^{1}$. There is a similar example of such 'acclamations' after the death of Domitian, when the senators invaded the curia and showered the most violent and injurious invectives over the dead body of the emperor ${ }^{2}$.

Tacitus takes these seditious cries as proof that the people were not sincere in their acclamations; he points out that the mob, which called out with such violence for the death of Otho, would probably be demanding the exact opposite on the same day, because of the tradition to flatter any prince with such exaggerated acclamations ${ }^{3}$. Dio supports Tacitus in this view in his description of the acclamations paid to Commodus in the late second century, and he shows how the people changed certain words of the acclamations which they had formerly used to pay court to Commodus, in order to make them completely ridiculous ${ }^{4}$. In this text, Dio describes the actual acclamations - he speaks of a kind of 'rhythmic swing' which once again puts one in mind of the slogans chanted by present-day marchers.

In his Panegyric, Pliny remarks that the emperors themselves should make it their duty to learn to distinguish true acclamations from the false ${ }^{5}$. He seems to be hinting that these acclamations have been used by the emperors as a means of running after adulation and honours: "non submovenda adulatio" - and he says that the important thing is not to resume their former position of power.

As with other cult-practices, acclamations made to the emperor gradually influenced the formal expressions of worship in the early

1 TAC. Hist. I 72, 3: «Eo infensior populus... concurrere ex tota urbe in Palatium ac fora et, ubi plurima volgi licentia, in circum ac theatra effusi seditiosis vocibus strepere...»

2 Suet. Dom. 23, 2: «Contra senatus adeo laetatus est, ut repleta certatim curia non temperaret, quin mortuum contumeliosissimo atque acerbissimo adclamationum genere laceraret. »

3 TAC. Hist. I 32, 1: «Sed tradito more quemcumque principem adulandi licentia adclamationum et studiis inanibus.»

${ }^{4}$ Dro LXXIV 2, 3.

5 Plin. Paneg. 75, 5: «Discant et principes acclamationes veras falsasque discernere habeantque muneris tui quod iam decipi non poterunt. Non instruendum illis iter ad bonam famam, sed non deserendum, non submovenda adulatio, sed non reducenda est.» 
Christian community ${ }^{1}$, and some of these 'laudes' have remained in the liturgy until present times. This was, however, a gradual development and there were only the first traces to be found in the writings of the first century Christians. Acclamations in the New Testament are only mentioned infrequently and they do not throw much light on their developing liturgical function. Perhaps the best-known New Testament acclamation is that of the 'first Palm Sunday', when Christ entered Jerusalem amidst the adulation of the crowds ": "And those who went in front and those who followed were all shouting 'Hosanna! Blessings on him who comes in the name of the Lord. Blessings of the coming kingdom of our father David. Hosanna in the highest heavens'» ${ }^{3}$. This was a true acclamation of royalty.

According to St. Jerome, 'hosanna' is a contraction of two words of Ps. CXVIII 25: 'salvum fac' - 'make safe' or 'save me' 4 . Whether or not the primitive sense of the word was known to the Jews on the first Palm Sunday, the word was transformed into a joyful acclamation, and it has remained ever since in the liturgy of the Roman church ${ }^{5}$. This word is completely messianic, and it was probably used in this sense as a recognition of Christ's messianic position.

There is a connection between the acclamations of 'hosanna' and the spreading of garments on the roads: "Great crowds of people spread their cloaks on the roads... ${ }^{6} \%$. This spreading of garments on the road was an extraordinary honour, coupled as it was with the enthusiastic acclamations of the people, and this fact was realized by some of the Pharisees. In the first century B. C., this honour was not unheard of, but it was exceedingly rare, and among the Romans

1 Cf. J. GAGÉ, La Victoire impériale dans l'empire cbrétien. RHPR (1933) pp. 370400, esp. p. 396.

2 Jn. XII 12-19; Lk. XIX 28-38; Mk. XI 8-11; Mt. XXI 1-11.

3 Mk. XI 9-10. Cf. O. Perler in Rivista di Archeologia Cristiana xlIII (1967) pp. $243 \mathrm{ff}$., who shows how the faithful at the Eucharist used the same formula as was used by the crowds at the entry of Christ into Jerusalem. These epiphanyacclamations were used in other liturgies: cf. p. 245, of his article entitled "Die Darstellung der Eucharistie auf dem Theodor-Mosaik in Aquileia».

4 Jer. Epistolae XX. J. Migne: PL XXII 377. Cf. J. E. Steinmueller \& K. Sullivan, Catbolic Biblical Encyclopaedia. N. T. New York City, 1949, p. 319. J. L. McKenzie, Dictionary of the Bible. London/Dublin, 1965, p. 372.

${ }_{5}$ Cf. M. J. LAGRANGe, Evangile selon saint Jean, p. 235.

6 Mt. XXI 8. ("Many people spread their cloaks on the road...» Mk. XI 8. "As he moved off, people spread their cloaks in the road..." Lk. XIX 36). 
was an honour accorded only to a few of their imperators. Cato the Younger was one of these few, and Plutarch relates how, at the end of his military career, he received honours which were unusual enough to receive special mention ${ }^{1}$. The soldiers went far beyond the accustomed praises and blessings, for they embraced Cato with tears, and threw down their mantles for him to walk over, and kissed his hands, these being honours which Romans rarely gave and rarely received.

With this in mind, it is easier to understand why those who witnessed the scene and realized the significance of the spreading of the garments on the road before Christ, called out from the crowds: "Master, check your disciples». They understood the implication in these acclamations and endeavoured to put an end to them. The reply of Christ shows how deeply conscious he was of his position, and, far from avoiding the implications of such demonstrations, he accepted them without reserve: "I tell you, if these keep silence, the stones will cry out» ${ }^{2}$.

St. Matthew gives a slightly different account but the essence of the attitude of Christ's adversaries is the same. Having seen the cure of the blind and the lame in the Temple, and having heard the shouts of the children, "Hosanna to the Son of David", the chief priests and scribes were filled with indignation. "Do you hear what they are saying?" they said to him. "Yes», Jesus answered, "have you never read this: 'By the mouths of children, babes in arms, you have made sure of praise'» ${ }^{3}$.

An interesting acclamation is related by St. Luke in the Acts of the Apostles ${ }^{4}$. Here we see an earthly ruler being acclaimed by the people in Caesarea, and it is important insofar as it is clearly recognized as part of cult-worship. The Tyrians and Sidonians sent a joint deputation to Herod Agrippa because their country depended on Herod's territory for food, and they were anxious to negotiate a treaty. Wearing their robes of state they were received by Herod who made a speech, seated on a platform. The discourse finished, the people acclaimed him with "It is a god speaking, not a man.» It is

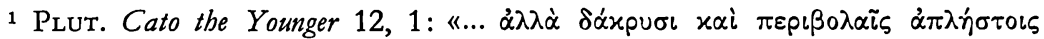

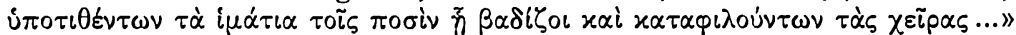

2 Lk. XIX 39-40.

3 Mt. XXI 15-16.

4 Acts, XII 21-23. 
not clear whether the ' $\delta \tilde{\eta} \mu \circ \varsigma^{\prime}$ refers to the Tyrians and Sidonians only, or if there were other people in the assembly. Whatever the case, it is of no great importance; Caesarea was a town principally composed of non-Jews, Greeks, Latins and Syrians ${ }^{1}$. It is obvious that a practising Jew would never have made such an acclamation ( $\theta \varepsilon \circ \tilde{u} \varphi \omega \nu \dot{n})$. This acclamation closely resembles that made to Nero after his return from Greece, when the populace acclaimed him 'iepd̀ $\varphi \omega v '$ ' - 'O Divine Voice' 2. These expressions could only be used by a polytheistic pagan. Herod did nothing to repudiate such acclamations, and thus he usurped the glory due to God alone. Soon afterwards, he died of a painful and disgusting illness, which St. Luke sees as the direct result of the impious flatteries: "At that moment, an angel of the Lord struck him down because he had not given glory to God. He was eaten away with worms and died» ${ }^{3}$.

A third acclamation of the New Testament is again one intended to convey recognition of divinity, but this time it is given to a popular pagan goddess. The incident is well-known but it is worth mentioning against this background of divine acclamations. Ephesus was the great centre of the cult of Artemis, and a disturbance broke out when it was realized the number of converts St. Paul was making ${ }^{4}$,

1 Cf. E. Jacquier, Les Actes des Apôtres. Paris, 1926, p. 373.

2 Dio LXII 20, 5. These acclamations are far removed in spirit from that of Ignatius of Antioch, who felt that God's voice was speaking through him, and that the Spirit was preaching through his words. Cf. To the Pbiladelphians 71: "I cried out... and said in a ringing voice - God's voice: 'Give heed to the bishop and to the presbytery and to the deacons.'» - J. A. KLEIST, The Epistles of St. Clement of Rome and St. Ignatius of Antioch. London, 1946, p. 87.

3 Acts XII 23. Cf. Josephus, Ant. Jud. XIX 344-346. There are slight variations in the account given by Josephus. During a festival for 'the safety of the emperor', Herod appeared early in the morning in a garment made completely of silver, which shone brightly as it reflected the rays of the sun. From different places in the crowd, his flatterers called out that he was a god, adding: «Be thou merciful to us; for although we have hitherto reverenced thee only as a man, yet shall we henceforth own thee as superior to human nature." Herod did nothing to turn these impious words away from himself, and all at once, he was afflicted with a severe pain. According to Josephus, Herod realized that although he had just been acclaimed immortal, he was about to die: «I, whom you call a god, am commanded presently to depart this life; while Providence thus reproves the lying words you have just now said to me; and I, who was called immortal, am immediately to be hurried away by death." Cf. H. J. Schoenfield, Saints against Caesar. London, 1948, pp. 95-99, for a synopsis of the career of Herod Agrippa.

4 Acts XIX 23-41 (cf. Pl. I and II). 
not only in Ephesus, but all over Asia. A silversmith named Demetrius summoned a reunion of his fellow-silversmiths and made a speech in which he pointed out that Paul's preaching threatened not only to discredit their trade of making and selling silver shrines of Diana, but also to diminish the prestige of the goddess in Asia and all over the known world. "This speech roused them to fury, and they started to shout "Great is Diana of the Ephesians» 1 .

The situation began getting out of hand, with everyone shouting out different things, until the Jews pushed Alexander up to the front so that he could explain the case to the crowds. Once it was realized that Alexander was a Jew, however, the crowd took up the acclamation to Diana and began to chant in unison 'Great is Diana of the Ephesians', and this continued for about two hours ${ }^{2}$. On this occasion the acclamation contained an element of protest, for the mob realized that Alexander, being a Jew, could not support the idea of the divinity of Diana. To the followers of Diana, both the Jews and Christians were enemies of their cult, and so their cries in honour of Diana could be interpreted as a protestation as much as an act of worship ${ }^{3}$.

The three examples of acclamations in the New Testament are all seen to be acts of worship, though each is in a different category. The first, the cries of Hosanna for Christ at his entry into Jerusalem, was a recognition of his Messianic status, and obviously significant when linked with the spreading of cloaks on the roadway and the waving of palm-branches. The second instance may be interpreted as the offering of divine honours to Herod, which resulted, according to the Christian point of view, in the painful death of the ruler as the direct punishment from God, because he had usurped the honours

1 W. M. Ramsay, The Church in the Roman Empire. London, 1903, p. 135. This author points out the discrepancy between the invocation 'Great Artemis' of the inscriptions, and the formal assertion 'Great is Artemis' of the Acts. ' $\mu \varepsilon$ ' $\alpha \varsigma^{\prime}$ ' is a frequent epithet of the gods; for example, Cybele, Syll. 1014.83 (3rd

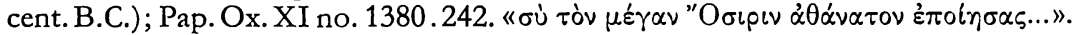
It is also used for kings in the East; e.g. to describe the Great King of Persia,

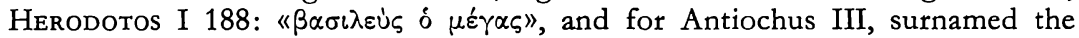

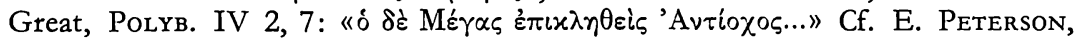

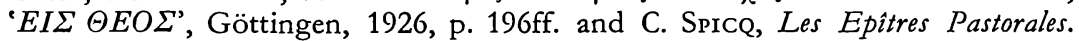
Paris, 1969, p. 640. Tit. II 13 Christ is called 'our great God and Saviour'. I Tim. III 16 ' $\mu \varepsilon^{\prime} \gamma \alpha c^{\prime}$ ' is used by the early Christians to describe the mystery of faith: "The mystery of our religion is very deep indeed.»

2 Acts XIX 28.

3 E. Jacquier, Actes, p. 589 v. 34. 
and titles due to God alone. The third acclamation is most clearly an act of worship, a 'divine honour' in the strict sense of the term, for it was made to the Greek goddess Artemis. It is obvious that the cries in unison were intended to convey genuine devotion and honour to the object of the cult. It is perhaps in this example that the full significance of acclamations may be understood; the expression of worship offered to a divinity. Although not every imperial acclamation would come into this category, yet it is clear that many were intended to convey divine honours, and it was for this reason, under Nero, that they became a more organized form of cult-worship ${ }^{1}$. The influence of such acclamations was felt in the early Church where one finds certain similarities in the chanted hymns of praise ${ }^{2}$.

The three above-mentioned acclamations are the most obvious in the New Testament but they do not exclude the possibility of other examples. Writing to the Philippians, St. Paul stressed that «every tongue should acclaim Jesus Christ as the Lord, to the glory of God the Father» ${ }^{3}$, and these words could have easily developed into a regular acclamation. Whether or not this would have been a conscious effort on the part of the Christians to provide a counterbalance for the similar imperial acclamations, there is not sufficient evidence to say, but the possibility nevertheless remains ${ }^{4}$.

\section{The Legend of 'Nero Redivivus'}

In many of the aspects of imperial cult-worship, there is a positive sense of the abiding presence of the emperor even after his death; in the use of cult-statues, this implication is particularly clear. A negative aspect of this 'omnipresence' is found in the legend which grew up around the person of Nero, and since this legend has been seen as the possible source of some phrases of the Apocalypse, this section

1 According to J. GAGÉ, La Victoire impériale dans l'empire chrétien. RHPR (1933), pp. 370-400, there are certain proofs of the existence of acclamations from the end of the second century and the beginning of the third. This seems to be an extremely late estimate; the author also points out that the three emperors who showed the greatest taste for the theatre and the circus, namely Nero, Domitian and Commodus, were the ones who made the most effort to surround themselves with some form of liturgy.

${ }^{2}$ H. J. W. Tillyard, The Acclamations of Emperors in Byzantine Ritual. ABSA XVIII (1911-12), pp. 239-260.

3 Phil. II 11.

${ }^{4}$ E. Peterson, Die Einbolung des Kyrios. Zeitschrift für systematische Theologie 7 (1931), p. 698, note 2 . 
will be devoted to a study of the development of this legend and the references to the expected 'return' of this emperor, which expressed a belief in the prolongation of the power and presence of Nero, and in this sense, was a form of inverted-cult-worship.

In Chapter XVII of the Apocalypse, St. John has the angel explain the symbol of the beast: "The beast you have seen once was and now is not; he is yet to come up from the Abyss, but only to go to his destruction" ${ }^{1}$. In Nero, many of the evil tendencies of Satan were present, and the beast "which had had the fatal wound and had been healed ${ }^{2}$ is generally thought to represent this emperor. According to M. Kiddle ${ }^{3}$, when the beast is spoken of in the present, the author is referring to 'the abiding presence of evil' personified in the emperor, and which is the true object of emperor-worship. The allusion to the 'eighth head' is not particularly clear, even in the modern exegesis dealing with this point, and the understanding of apocalyptic writings is difficult for the modern mind, but it is obvious that what John wanted his teaders to understand, was that while the beast was similar to its predecessors, yet it was totally distinct from them.

Of the various interpretations of this phrase of the Apocalypse ${ }^{4}$, the one which connects it with the idea of the return of Nero seems to be the most reasonable. The fact that John himself had lived through the reign of Nero, and had no doubt seen for himself the effect that such an emperor would have had on the people of his time, would allow for this reference to a historical fact, well-veiled though it might be in apocalyptic language ${ }^{5}$. However, though it is likely that the idea of a 'return of Nero' influenced the thought behind Chapter XVII, it was probably interpreted more generally as a resurging of the power of evil, which, to the early Christians, had strong connections with the pagan Roman Empire, and all that was implied by compliance to the regulations observed by those who worshipped the emperor, however exterior a formality this might have been. Even the wording of the relevant phrase is the

1 Apoc. XVII 8.

2 Ibid. XIII 12.

3 M. KIDdLe, The Revelation of St. Jobn, London, 1940, p. 346.

${ }^{4}$ Cf. Lexikon der Alten Welt, col. 2079.

5 R. MacMullen, Enemies of the Roman Order. London, 1967, p. $143 \mathrm{f}$. This author mentions two members of the imperial house who were said to have 'returned': Agrippa Postumus in A.D.14, and Drusus in Greece, Ionia and the Cyclades (TAC. Ann. V 10. Dio LVIII 25, 1). 
antithesis of those words in Chapter I of the same book, applying to God Himself: "I am the Alpha and the Omega, the beginning of all things and their end, says the Lord God; He who is, who was, and is still to come, the Almighty" ${ }^{1}$.

According to popular belief, the great fire of Rome in 64 A. D. was attributed to Nero, and it had made a lively impression on Roman citizens throughout the Empire. Even after his death, rumours persisted, leading many to believe that Nero would return, revivified, to wreak vengeance on those who had treated him with scorn or fury. After the death of Nero, the disposal of his body was a private affair between three women; a fact which paved the way for uncertainty and distrust. It was therefore hardly surprising that the rumour spread abroad that the emperor was not dead but seeking refuge and military aid in the East. This attitude of mind is common among men of all times, but more particularly before the era of mass communications, which have greatly lessened the possibility of such rumours gaining credence, since the whole world is now aware of an event shortly after it has occurred. One cannot judge just how far these rumours were the fruit of a subtle programme of propaganda, but it is certain that they are not phenomena merely of the Ancient World ${ }^{2}$.

Already before the final crisis, Nero had considered the possibility of saving his life, if not his position as emperor; Suetonius mentions the various projects which he had in mind shortly before his suicide in $68 \mathrm{~A}$. D., and the fact that he thought over the possibility of handing himself over to the Parthians, added substance to the subsequent rumours which developed after his death. Self-deliverance to the Parthians was not to be his only possibility of escape; he considered giving himself up to Galba, who was, at this time in New Carthage, gaining popularity and support, particularly from the Three Gauls, or attempting to gain public sympathy by addressing himself to the people dressed in mourning, a role which no doubt appealed to his theatrical taste. It seems, however, that even Nero did not have complete faith in his powers to win over the people,

1 Apoc. I 8.

2 As E. B. Allo points out, L'Apocalypse, Paris, 1933, pp. 286-289, similar «resurrections» have occurred in more recent times with the legends which grew up around Dmitri of Russia and Louis XVII of France. 
and he made provision for their refusal of his request for pardon, in settling that at least he would be accorded the prefecture of Egypt - the most important province of the Empire, since Italy depended on it to a large extent for the grain-supply. These schemes are described by Suetonius only ${ }^{1}$.

Thus the strong belief grew up that Nero had taken refuge with the Parthians, these latter being the staunch enemies of everything Roman, and rumour held that he would return at the head of a great army, seeking the downfall of the Roman Empire, and of the enemies who had betrayed him ${ }^{2}$.

This rumour was further strengthened by the fact that even before Nero was deposed, the coming deposition had been predicted by the court astrologers ${ }^{3}$. However, some promised him that after his deposition, he would become the master of the East; others went so far as to specify the Kingdom of Jerusalem, and many predicted that he would regain all his former power ${ }^{4}$.

Suetonius further relates that twenty years after Nero's death, a pretender made himself known in the East as the resurrected emperor, and he won such renown for himself with the Parthians, that they supported him energetically and only delivered him up to the Romans

1 Suet. Nero 47,2: "Varie agitavit, Parthosne an Galbam supplex peteret, an atratus prodiret in publicum proque rostris quanta maxima posset miseratione veniam praeteritorum precaretur, ac ni flexisset animos, vel Aegypti praefecturam concedi sibi oraret. »

${ }^{2}$ For a connection with the Parthians cf. the Sibylline Oracles IV 119-124: «... and then shall a great king from Italy flee away like a deserter, unseen, unheard of, beyond the ford of the Euphrates, after he has polluted his hands with the hateful murder of his mother, doing the deed with wicked hand. And many round his throne shall drench the soil of Rome with their blood, and when he has fled beyond the land of Parthia.» Cf. H. N. BAtE, The Sibylline Oracles, London, 1918, pp. 37-41. TAcitus, Ann. XIV 3-8, and Suetonius, Nero 34 give details of Nero's "hateful murder of his mother" in 59 A. D. Cf. also, Fr. TAEger, Charisma. Studien zur Geschicbte des antiken Herrscherkultes. Stuttgart, 1960 . II, pp. 566-575.

3 Suet. Nero 40,2: "praedictum a mathematicis Neroni olim erat fore ut quandoque destitueretur.»

${ }_{4}$ Ibid. 40,3: «Spoponderant tamen quidam destituto Orientis dominationem, nonnulli nominatim regnum Hierosolymorum, plures omnis pristinae fortunae restitutionem.»Cf. Sib. Or. III 63: "Now from the Sebastenes shall Belial return and he shall move the high mountains... and do many signs among men, yet shall his signs not be fulfilled. But he leads many astray, and shall deceive many faithful and elect of the Hebrews and lawless men besides, who never hearkened to God's word." There is no proof who the Sebastenes were, though some commentators favour the Samaritans. 
after many difficulties on their part ${ }^{1}$. Suetonius writes this as being an event which he himself remembers from his boyhood, for he deliberately inserts the phrase 'during my adolescence' (adulescente me). At this point, he is no longer writing from hearsay, however close to the truth this may generally be; he is commenting on a happening which he remembers from his own experience, and which obviously made an impression on him since he remembers when it took place.

The same author notes furthermore that this Nero-figure appeared twenty years after the emperor's death; a generation after the historical Nero had left the scene of action. This fact also adds weight to the arguments of those who feel that there is a connection between the theme of Nero Redivivus and that of the Apocalypse; the appearances of these false Neros kept alive the image of the dead emperor, with all his satanic vices, and with each re-appearance, a new wave of terror and curiosity must have passed over the empire. It is noteworthy that these appearances took place in the more Easterly part of the empire; perhaps the Eastern mind was more susceptible to such manifestations, and more prone to believe in the impostors of Nero, since, being farther from Rome, the people would have had less chance of having known the Emperor intimately, and therefore, such a pretender would have a greater chance of success than in Italy, for example, where the emperor was a more familiar figure.

The 'resurrected Nero' who appeared in the eighties of the first century, was not the only one of his kind, for already there had been at least two other false alarms recorded by Dio, Tacitus and Zonaras. The account given by Dio is the most brief and to the point; he gives no details except the bare facts ${ }^{2}$. "About this time», that is, according to the events which he had previously been recording, in 69 A.D., a man was caught who was impersonating Nero, but Dio knows little about this person, not even his name or place of origin - neither does this author give any indication where this 'Nero' appeared, though it seems likely that he might be the same as is mentioned by Tacitus, though the latter seems to place this appearance in the year

1 Suet. Nero 57,4: «Denique cum post viginti annos adulescente me extitisset condicionis incertae qui se Neronem esse iactaret, tam favorabile nomen eius apud Parthos fuit, ut vehementer adiutus et vix redditus sit.»

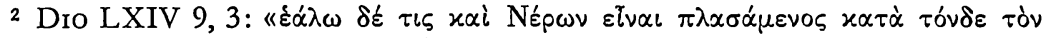

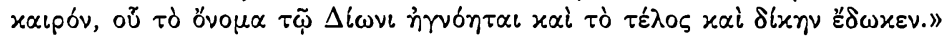


70 A.D. However, as both these introduce the occurrence rather vaguely with the words 'about this time', it is not out of the question to assume that they are relating the same event. Dio concludes his account in noting that finally the imposter 'paid the penalty', so one may conclude that he was captured and put to death, to discourage any more would-be Neros, as such manifestations could easily disrupt the unity of the Empire.

The account given by Tacitus is more detailed, yet hardly more satisfactory, since we learn nothing new as to the outcome of this resurrection; in fact, Tacitus gives no indication as to the fate of this 'Nero', and his short account finishes vaguely ${ }^{1}$. Although Tacitus seems to include this event in the year 70 A.D., it is probable, as has been mentioned above, that it is the same as that given by Dio, though there is no common detail in the two accounts which would make it possible to come to a more precise conclusion. The vague phrase 'sub idem tempus' is not used with any idea of a precise date; it is commonly used in such historical accounts to introduce an event and to link it with those which have been related before it.

Tacitus, however, does fix the provinces of the Empire concerned with this apparition; the rumours apparently infiltrated into Asia and Achaia from the East that Nero 'was about to arrive', which spread alarm throughout this part of the Roman world. It might be supposed that John and his followers would have been affected by this rumour; the Christians would have dreaded a repetition of the persecution suffered under Nero and would have been thrown into consternation at the thought of his possible return. Having accepted the thesis that the Apocalypse was written during the reign of Domitian, it would seem justifiable to link the idea of Nero Redux with that of the return of the beast, as given in the Apocalypse, since a study of the various accounts of the legends surrounding Nero after his death, emphasize the strong elements of fear and uncertainty which underlie the birth of these rumours. Though John may not have had one particular event in mind, or even the person of Nero directly, the whole atmosphere must have influenced his writings to a large extent, and formed a background for his thought which he, in turn, passed on to his disciples.

1 TAC. Hist. II 8, 1: «Sub idem tempus, Achaia atque Asia falso exterritae velut Nero adventaret, vario super exitu eius rumore eoque pluribus vivere eum fingentibus credentibusque.» 
Tacitus remarks rather pointedly that all manner of rumours had been spread around concerning the death of Nero, giving the impression that these were the result of a definite policy rather than the work of some hysterical groups. This would fit in with what was said earlier about the accounts of the 'returns' of other notorious men throughout the ages, that they were the result of skilful propaganda. In much the same way, one can see that such rumours after the death of Nero could have been most beneficial to Parthian interests, because fear of a superior force can have a great psychological impact on a people, and as the years went on, the figure of Nero became more and more mysterious. Renan mentions «an ardent Neronian who forced peaceable people to recognize Nero - he re-established his statues and ordered them to be honoured... Rather than lend themselves to acts of apostasy, some of the believers in Ephesus were exiled; we may suppose that John was of this number. This incident plays a large part in the Apocalypse and was perhaps its prime origin" ${ }^{1}$. This is perhaps going too far - the Apocalypse was no doubt influenced to a great extent by the climate of the time, and the troubled atmosphere engendered by such apparitions of this emperor who had come to be looked upon as the Anti-Christ, but it is assuming much to narrow down the influences to one event at a given time. The belief was strong, however, that Nero would return to take revenge for Rome's rejection of him, and this does seem to be behind some of the visions of the Apocalypse ${ }^{2}$.

The allusions of Tacitus are concluded with another remark on the general attitude towards these rumours: "pluribus vivere eum fingentibus credentibusque. » Many said falsely that he was alive - they saw that it was to their own advantage to stir up these rumours concerning Nero - while others believed truly that he was alive, victims of these tales and awaiting his appearance with trepidation ${ }^{3}$.

Zonaras mentions a Nero Redivivus in two different paragraphs, and for the first time we learn the name of a pretender - Terentius

1 E. Renan, The Antichrist. The History of the Origins of Christianity. Bk. 4. London, no date, p. 173.

2 Apoc. XVI 12 is probably a reference to this return of Nero: "The sixth angel emptied his bowl over the great river Euphrates; all the water dried up so that a way was made for the kings of the East to come in.»

3 There are later references to the popular belief that Nero was alive, e.g. Lactantius, De mortibus pers. 2, 8. Jerome, Comm. in Dan. XI 19. Augustine, De Civ. Dei XX 19. Cf. H. N. BAte, Sybilline Oracles, p. 40. 
Maximus ${ }^{1}$. Zonaras places this impostor in the reign of Titus, about the year 80 A.D., so it is unlikely that he is the same one as is mentioned by Tacitus ${ }^{2}$. Although the dates are not identical, it is more likely that this 'Nero' is one and the same as the one mentioned by Suetonius, since the former received similar support from the Parthians, being aided by a Parthian general on the Euphrates.

Shortly before this account, Zonaras refers to a man who pretended to be Nero from his resemblance to that emperor and who caused consternation in practically the whole of Greece ${ }^{3}$. He there assembled a band of criminals, and set out for Syria, with the hope of winning the legions over to his cause. Although his initial followers were criminals and bandits, it would appear that many believed this fable, and finally when he was passing through Cynthus, he was arrested and put to death.

These various examples all underline the fact that the emperor, alive or dead, exercised a considerable influence over public thought at this period when John was writing the Apocalypse. These writings do not directly condemn the emperor himself, but the exaggerations which had developed around his person, and in particular, those forms of worship which gave to a man that honour which belongs to God alone. The legends of Nero depict one aspect of the impression that such worship would have had on the contemporary mind of the time, all of which, for the author of the Apocalypse, is the worship of Anti-Christ and to be condemned at all costs.

1 Zonaras, Epitome Historiarum. Leipzig, 1868 (XI 18, pp. 54-57).

2 Cf. Sib. Or. IV 130-139: "But when from a cleft in the earth, in the land of Italy, a flame of fire shoots out its light to the broad heaven, to burn up many cities and slay their men, and a great cloud of fiery ashes shall fill the air, and sparks fiery red shall fall from heaven, then should men know the wrath of God of Heaven, because they destroyed the blameless people of the godly. Then shall come to the West the strife of war stirred up, and the exiled man of Rome, lifting up a mighty sword, crossing the Euphrates, with many tens of thousands.। This fits in as far as dates are concerned, for the eruption of Vesuvius and the resulting destruction of Pompeii and Herculaneum took place in 79 A. D. (Dio LXVI 21-23. Pliny, Letters VI 16).

3 Op. Cit. XI 15 D, pp. 45-6. 


\section{SIGNIFICANCE OF THE «SECOND BEAST» OF THE APOCALYPSE AND ITS IMPLICATIONS IN IMPERIAL WORSHIP}

\section{a) The Priesthoods}

"Then I saw a second beast; it emerged from the ground... (it) was servant to the first beast, and extended its authority everywhere, making the world and all its people worship the first beast» ${ }^{1}$.

The 'second beast' of the Apocalypse is described against a background of the imperial cult as it existed in Asia Minor during the latter part of the first century. By this time, the provincial priesthood had become very powerful and the position of the priest greatly coveted ${ }^{2}$, for it formed the link between the imperial administration and the ordinary life of the provincials, and was thus a privileged and responsible position ${ }^{3}$. This 'beast' is obviously a 'middleman' between the emperor and the people for the promotion of the imperial cult; from the hints given in the Apocalypse that this beast made the people worship the first beast, that it worked miracles, and it persuaded people to put up a statue in honour of the first beast, the second beast seems obviously the symbol of the imperial priesthood and the pagan priesthood insofar as it was used for the furtherance of the imperial cult ${ }^{4}$.

1 Apoc. XIII 11-17 where the complete description of the second beast.

2 Cf. H. A. A. Kennedy, Apostolic Preaching and Emperor-Worship. The Expositor, April (1909), pp. 289-307. In particular, p. 290.

3 M. W. Hoffman Lewrs, The Official Priests of Rome under the Julio-Claudians. American Academy in Rome, Papers and Monographs XVI, 1955, pp. 17-18.

4 Cf. M. Kiddle, The Revelation of Jobn. London (1940) 1947, p. 253. For this author, the second beast symbolizes the priests of the imperial cult. E. B. AlLo, L'Apocalypse. Paris, 1953, p. 229, states that under Domitian, the conditions of the imperial cult were far from paralleling the description of John; there was not yet a 'second beast', or at least, it had not yet allied itself with the first. Cf. also, W. BARCLAY, The Revelation of John, Edinburgh, 1959, p. 113, who sees this beast as the whole provincial organization of magistrates and priesthoods designed to enforce Caesar-worship. 
In order to appreciate the significance behind the apocalyptic expression of the 'second beast', a survey of the development and importance of the imperial priesthood is necessary at this point. The establishment of priests of the deified emperor was an important step in the organization of emperor-worship, though it still left room for the continued support of the major colleges. Already in 44 B.C., Julius Caesar had acquired a Flamen Iulialis among the various honours - temple, altars, statues and sacred couch - which are listed by Suetonius ${ }^{1}$. Dio sees the institution of the flaminate as the culminating point in the exaggerated honours acquired by Caesar; he was finally addressed as Jupiter Julius and he ordered a temple to be consecrated to him and his Clemency. Antony was finally elected their priest, which, Dio says, was just like some Flamen Dialis ${ }^{2}$. The priesthood of Augustus - a flamen Augustalis was instituted in 14 A. D. - gradually developed in importance, as we learn from the inscriptions. A body of twenty-one men were chosen by lot from the principal citizens and to these were added Tiberius, Drusus Claudius and Germanicus. The Sodales Augustales should be distinguished from the Augustales in the provinces, recruited from the freedmen and who were presided over by the Seviri in each locality. Dio ${ }^{3}$ adds that, at the same time as Augustus was declared immortal and was assigned priests and sacred rites, Livia was named his priestess. Nevertheless, the priests of the official cults continued to give their support to the emperor, and they were given a privileged place in imperial processions, and for the offering of vows and sacrifices for the safety and well-being of the emperor, for Augustus realized the need he had for support in his work of religious reform in the Empire.

One of the best-known portrayals of a procession in sculpture is that on the sides of the Ara Pacis and it must have immortalized just one of many such processions during the Empire. On the south side, the four main flamines are discernable - the flamen Dialis, the flamen Martialis, the flamen Quirinalis and the flamen Iulialis ${ }^{4}$.

1 SuEt. 76, 2: «Templa, aras, simulacra iuxta deos, pulvinar, flaminem.»

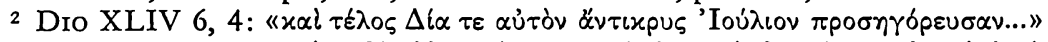

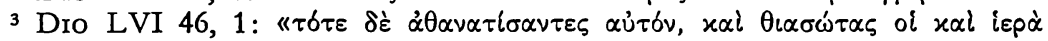

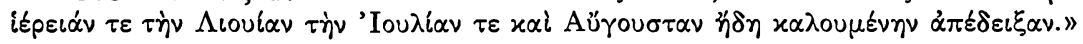

4 Bibliography for the Ara Pacis: G. Rodenwaldt, Kunst um Augustus. Berlin, 1942, pp. 34-52. Pls. 29, 31, 32. - G. Moretrr, Ara Pacis Augustae. Romae, 
Another important procession connected with the imperial cult in which the priests took part, was at Augustus' funeral. Dio describes the ceremony ${ }^{1}$; how, once the body of the dead emperor had been placed on the funeral pyre, all the priests walked round it first, followed by the knights, the cavalry-men and the infantry. We learn from this text that the priests took precedence over those with military titles, and though the priesthood did not confer on its holders any political powers, it nevertheless gave a certain distinction and prestige.

Pliny sums up what must have been the general attitude towards such an office, in a letter to Maturus Arrianus ${ }^{2}$, replying to his congratulations at having received the office of augur. According to Pliny, it is fitting that one should be congratulated on such an occasion because conferring the priesthood is a mark of esteem on the part of the emperor. Pliny is flattered; he has been given a certain status, which in this case is for life, and he is well-conscious of the honour he has received. He supplements this view in a letter to the emperor Trajan, where he asks to receive the office of augur or septemvir because there are vacancies. Pliny looks on such a gesture on the part of the emperor as a mark of esteem for his loyalty, and he adds, in spiritual bribery, that such a position in the priesthood would give him the right to pray to the gods for his Emperor in the name of the whole state, which at present he could do only as a private individual ${ }^{3}$.

Apart from esteem, the priests obtained material concessions and privileges, an obvious one being the right to sit at front seats in the

1948. - J. Charbonneaux, L'art au siècle d'Augustc. Lausanne, Paris, Bruxelles, New York, 1948, pp. 86-89, pl. 85. - J. Toynbee, The Ara Pacis Re-considered. PBA XXXIX (1953), pp. 67-95. - I. ScOTt RYBERG, Rites of the State Religion in Roman Art. MAAR (1955), pp. 38-48. - H. KAEHLER, Rom und seine Welt. Munich, 1958. Pls. 100-105. - S. Weinstock, Pax and the Ara Pacis. JRS L (1960), pp. 44 58. Pls. 5-9. - J. Toyndee, The 'Ara Pacis Augustae'. JRS LI (1961), pp. 153-156. G. Charles-Picard, L'Art Romain. Paris, 1962. - Sir M. Wheeler, Roman Art and Architecture. New York, 1964, p. 163. - Тн. Kraus, Das römische Weltreich. Berlin, 1967, pp. 224-226. Pls. 182-185.

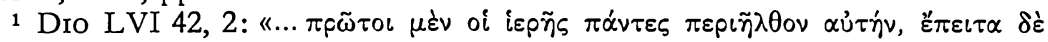

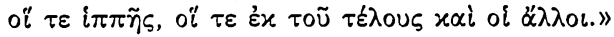

2 Pliny, Letters IV 8.

3 Ibid. X 13: "Cum sciam, domine, ad testimonium laudemque morum meorum pertinere tam boni principis iudicio exornari, rogo dignitati, ad quam me prouexit indulgentia tua, uel auguratum uel septemuiratum... adicere digneris.» 
theatre. We are told that Gaius did not start the chariot-racing himself, but watched the spectacle from a front seat with his sisters and his fellow-priests of the Augustan order ${ }^{1}$. Although not giving any great influence to individuals, these types of privileges certainly added to the status of a man and would have lent an additional charm to the position.

The vows offered up by the priests for the good health of the emperor were looked upon as special honours and so the priests could become tools in imperial hands when the desire to flatter was strong enough. We see how jealous Tiberius was when the pontiffs and the lesser priests offered the same prayer for Nero and Drusus as for himself. This had been done as an additional honour to the emperor more than as an honour towards the family of Germanicus, but Tiberius did not interpret this gesture in this light, seeing it more as the according of similar honours to these two boys as he had received in his old age ${ }^{2}$.

Sacrifices and games in honour of the emperor were under the supervision of the priests, which were occasionally instituted in gratitude for the safe return of the emperor. Augustus had emphasized this point in his Res Gestae when he speaks of the consecration of two altars, one to Fortuna Redux and the other to the Pax Augusta, which the Senate voted "in honour of my (Augustus') return». The altar of Fortuna Redux, dedicated on October 12th, 19 B.C., was near the temple of Honour and Virtue at the Porta Capena, and the pontiffs and Vestal virgins were ordered to perform a yearly sacrifice on the anniversary of the day on which Augustus returned from Syria ${ }^{3}$. The day itself was named the Augustalia and this in itself was a great honour; one sees how the priesthood was brought into close contact with the imperial cult. A similar dedication was after the return of Augustus from Spain and Gaul after «successful operations in those provinces», after a three years' absence from 16 to

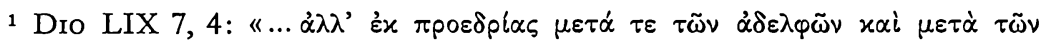

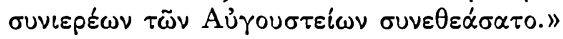

2 TAC. Ann. IV 17, 1: «Pontifices, eorumque exemplo ceteri sacerdotes, cum pro incolumitate principis vota susciperent... Nam Tiberius haud unquam domui Germanici mitis, tum vero aequari adulescentes senectae suae impatienter indoluit.»

${ }^{3}$ Res Gestae II 11: "Aram Fortunae Reducis iuxta aedes Honoris et Virtutis ad portam Capenam pro reditu meo senatus consacravit, in qua pontifices et virgines Vestales anniversarium sacrificium facere iussit.» 
13 B.C. Again the Senate voted the consecration of an altar, this time in honour of the Augustan Peace, and on it the magistrates, priests and Vestal virgins were ordered to make annual sacrifice ${ }^{1}$.

Games in honour of the emperor were under the supervision of the Sodales Augustales. These games, first celebrated in 9 B.C., were held annually during the first part of the month of October - after 14 A.D., they lasted for ten days. The tribunes of the people had asked that these games should be permitted at their cost, which, with the 'fasti' should be called Augustales ${ }^{2}$. Tacitus mentions these games again when he relates how during the first celebration, there were disturbances caused by rivalry between the histrions ${ }^{3}$.

In 22 A.D., Livia became ill and the Senate voted a public supplication with a performance of the Great Games to be held by the pontiffs, the augurs and the three sacred colleges: the Quindecimviri sacris faciundis, the Septemviri Epulones and the Sodales Augustales ${ }^{4}$. There are numerous examples of games under the direction of the priests - the anniversary of the death of Sejanus was celebrated by horse-races and wild-beast hunts under the direction of the members of the four principal priesthoods and of the Sodales Augustales, which Dio notes as one of the innovations of the reign of Tiberius ${ }^{5}$.

We hear of various honours accorded to Caligula in which the four colleges of priests held an important role. For example, each year on a certain day, the colleges, followed by the Senate, had to carry a golden shield to the Capitol, accompanied by young people of noble birth who sang a hymn in honour of the emperor's virtues ${ }^{6}$. Caligula is quite clearly making use of the priesthood for the furtherance of his own cult, which would make it «the servant of the

1 Ibid JI 12: «... aram Pacis Augustae senatus... consacrandam censuit in qua magistratus et sacerdotes virginesque Vestales anniversarium sacrificium facere iussit.»

2 TAC. Ann. I 15, 3: "Inter quae tribuni plebei petivere ut proprio sumptu ederent ludos, qui de nomine Augusti, fastis additi, Augustales vocarentur.»

3 Ibid. I 54, 3: «Ludos Augustales tunc primum coeptos turbavit discordia ex certamine histrionum.»

4 Ibid. III 64, 3: «Sed tum supplicia dis ludique magni ab senatu decernuntur, quos pontifices et augures et quindecimviri septemviris simul et sodalibus Augustalibus ederent."

5 Dro LVIII 12, 5.

6 SuEr. Cal. 16,11: "Quas ob res inter reliquos honores decretus est ei clipeus aureus, quem quotannis certo die collegia sacerdotum in Capitolium ferrent, senatu prosequente nobilibusque pueris ac puellis carmine modulato laudes virtutum eius canentibus.» 
first beast who extended its authority everywhere.» The young nobles who sang hymns in Caligula's honour were the fore-runners of Nero's Augustiani, officially formed in the late fifties to ascertain the acclamations and hymns which would later take on a considerable importance as honours in the imperial cult.

There is no doubt that the priesthoods gave a much-coveted status, for it presupposed that those who received these positions were pre-eminent in age or reputation ${ }^{1}$. Although in itself not political, and not leading directly to advancement in political spheres, the conferring of a priesthood was nevertheless a sign that the emperor appreciated the talents and character of a man, and in this way, was an indication of better things to come ${ }^{2}$.

Since the early years of Augustus' reign, the imperial cult had been well-established in the province of Asia, for the 'koinon' of Asia had been organized in 29 B.C. with the aim of propagating the cult of the goddess Roma and that of the reigning emperor. In the same year, a temple was erected at Pergamum, but the provincial assembly met in the different towns of the province - Ephesus, Smyrna, Pergamum, Sardis, Cyzicus, Laodicaea and Philadelphia and each in turn was the seat of cult ceremonies for the emperor. The actual centre of cult was at Ephesus and a temple to Roma and Augustus had already been built within the precincts of the Artemision ${ }^{3}$. This is not the only Augusteum in the province and other temples existed at the other chief provincial cities for the worship of the deified Augusti.

There seems to have been a certain amount of jealousy between the cities of Ephesus and Smyrna, both disputing which should hold the pre-eminence. A letter from Antoninus Pius to the magistrates and people of Ephesus ${ }^{4}$ is an attempt on the part of the emperor to end the dispute. Ephesus had always enjoyed a certain precedence; she led in the procession which opened the yearly festival in honour

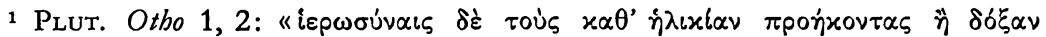

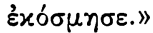

2 SUEт. Vit. 5,1: "Trium itaque principum indulgentia non solum honoribus verum et sacerdotiis amplissimis auctus, proconsulatum Africae post haec curamque operum publicorum administravit...»

3 Cf. E. L. Hrcks, 'Ephesos' in the Collection of Ancient Greek Inscriptions in the British Museum. Oxford, 1874, ed. C. T. Newron. Part III. Sect. II. No. DXXII, p. $177 \mathrm{f}$.
}

4 Ibid. No. CCCCLXXXXIX, p. $153 \mathrm{f}$. 
of the emperor, and her position was recognized by the Roman government.

Gradually the imperial cult took firm hold in Asia Minor; Gaius ordered a temple to be set apart for his worship at Miletus in the province of Asia and he gave as his reason the fact that Augustus had already chosen Pergamum, Tiberius Smyrna, while Diana had a well-established cult in Ephesus. None of these is the true reason which, Dio states, was Gaius' intention to appropriate the beautiful temple which the Milesians were building in honour of Apollo ${ }^{1}$.

The cult under Domitian took on a new significance and the limited rights of the Asiarch were supplemented by the increased influence of cult practices ${ }^{2}$. As the political unity of the empire was expressed through the common bond of imperial worship, the festivals and games took on a deeper meaning and thus the office of 'flamen' or 'sodales' carried with it distinct overtones not previously perceptible. As the Christian community became more organized, so did legislation against those practices or professions which might prove harmful to a Christian aspirant. In his treatise on the Apostolic Tradition, Hippolytus professes to record those practices in rites and customs which were already established in the Christian Church at the end of the second century. In the sixteenth chapter of his treatise, Hippolytus lists those crafts and professions forbidden to Christians, so that enquiry could be made of those desiring instruction in the Christian faith. Speaking of idolatry ${ }^{3}$, the author states that a priest or keeper of idols has either to desist from these practices or else «let him be rejected».

No doubt the author had the deeper implications of the festivals and games in his mind, when he wrote that not only were charioteers and those taking an active part in the games to be rejected unless they gave up these practices, but even those who went to the games as spectators would be similarly judged ${ }^{4}$. This ruling applied to those taking part in gladiator or wild-beast shows in the amphitheatre, gladiators, trainers of gladiators and those concerned with

1 Dro LIX 28, 1.

2 Cf. E. Stauffer, Christ and the Caesars. London, 1955, pp. 167-169.

3 Hippolytus, Apost. Trad. XVI 16. Cf. G. Dix, The Treatise on the Apostolic Tradition of St. Hippolytus of Rome (Reissued by H. CHADwICK) London, 1968.

4 Ibid. XVI 14. 
wild-beast shows, even down to the public officials; all these had to choose between their occupations and their faith.

Sculptors and painters were «to be taught not to make idols» and it is possible that Hippolytus also had in mind the makers of imperial statues and other divine representations of the emperor ${ }^{1}$.

The idea of the priesthood being the servant of the Roman Empire and, in particular, of the imperial cult, remained in the minds of Christians until they were so organized that they could make a stand against the 'second beast'. Early in the fourth century, the synod of Elvira produced several canons dealing with the pagan 'flamines' and the position of Christians who were legally bound to fill this post. Some of the canons seem exceedingly severe, as canon 2, which states that Christians who have sacrified to idols during their flaminate, and who have given public pagan games, cannot receive communion even at the point of death ${ }^{2}$. There is a slight relaxing in this ruling for those 'flamines' who have not offered sacrifices but have been responsible for the celebration of games. In this case, after a previous penance, communion may be received at the end of their lives ${ }^{3}$.

According to this Synod, to fulfil all the duties of the flaminate would mean to sacrifice to idols, to commit murder by preparing for the games, and to take part in acts of immorality in some of the plays which were produced. Sacrifice to or for the emperor was looked on as the most grievous sin, and if all the other duties of a flamen had been carried out, while omitting the sacrifices, a man might receive communion after a suitable penance, or, if a catechumen, be baptized after a trial of three years ${ }^{4}$.

1 Hippolytus, Apost. Trad. XVI 11. Other crafts and professions were forbidden to Christians, including men supporting harlots, schoolmasters teaching children worldly knowledge, though if they have no other trade, they are to be forgiven, harlots, magicians and concubines. Cf. XVI 10, 13, 20-23.

2 Hefele, Histoire des Conciles, I p. 221 ff.: Canon 2: «Flamines, qui post fidem lavacri et regenerationis sacrificaverunt, eo quod geminaverint scelera accedente homicidio, vel triplicaverint facinus cohaerente moechia, placuit eos nec in finem accipere communionem.»

3 Canon 3: «Item flamines, qui non immolaverint, sed munus tantum dederint, eo quod se a funestis abstinuerint sacrificiis, placuit in finem eis praestare communionem, acta tamen legitima paenitentia. Item ipsi si post paenitentiam fuerint moechati, placuit ulterius his non esse dandam communionem, ne illusisse de dominica communione videantur.»

4 Canon 55: «Sacerdotes qui tantum coronas portant, nec sacrificant nec de suis sumptibus aliquid ad idola praestant, placuit post biennium accipere commu- 
Thus the activities of the 'second beast' were looked upon as grave issues in the early fourth century, serious enough to cause a life-long separation from the Christian Church and they were even looked upon as unpardonable. By this time, the role of the priests had developed in importance and significance, and it fitted in more completely with the words of the Apocalypse.

Examples of the position and role of the imperial priesthood and, in fact, all pagan priesthoods, which were used for the advancement of the imperial cult, have shown its various activities during that cult's early development, yet no reference has been made to the miracles worked at the instigation of the priests: "And it worked great miracles, even to calling down fire from heaven onto the earth while the people watched. Through the miracles which it was allowed to do, it was able to win over the people of the world...» ${ }^{1}$. There is nothing in the texts of the first century to suggest the source of these verses, but they remind one of the miracles at Alexandria during the early part of the reign of Vespasian, which were very likely the result of the co-operation of the priests in an attempt to make as firm a basis as possible for this emperor's rule, especially in the eyes of the masses ${ }^{2}$.

\section{b) The Significance of the Term 'Image of the Beast' and the Importance of Statues in Imperial Cult Worship}

The Apocalypse informs us that the 'second beast' was able to persuade the people «to put up a statue in honour of the beast... It was allowed to breathe life into this statue, so that the statue of the beast was able to speak, and to have anyone who refused to worship the statue of the beast put to death" ${ }^{3}$.

One of the most usual forms of imperial worship took place before the statue of the emperor, before which honour could be

nionem ". This Canon makes reference to a time of persecution which is seemingly not too distant, another connection with the 'second beast', who "was allowed to make war against the saints.»

1 Apoc. XIII 14-15.

2 Cf. K. Scort, The Imperial Cult under the Flavians. Stuttgart/Berlin, 1936, p. 13: «... it does seem that someone... was working with the priests of Serapis to provide for Vespasian the 'caelestis favor et quaedam in Vespasianum inclinatio numinum' (TAC. Hist. IV 81), the 'auctoritas et maiestas' (SuEt. Vesp. 7, 2) which he lacked.»

3 Apoc. XIII 14-15. 
rendered either as a mark of loyalty, as in the time of Trajan, or as a public act of religion on the part of the faithful. Veneration to the statues of rulers had a long history, especially in the East, although the practice was also quite common in the Roman Republic, and sometimes attained seemingly exaggerated proportions as in case of the Gracchi, when the people set up their statues in a conspicuous place, "and sacrificed and prostrated themselves before the statues of the brothers every day, as though they were visiting the shrines of the gods» ${ }^{1}$.

From the Old Testament, one of the best-known cult-statues is the golden image of Nebuchadnezzar; we learn how the governors, magistrates, rulers and chief men from all his dominions were assembled together before this golden image of the king. The command was issued that at a given signal, all should prostrate themselves before the statue and worship it. The threat was forthwith laid before the crowd, that should anyone neglect this worship, he would immediately be thrown into a fiery furnace. This threat of death was reiterated after the refusal of the three Jews, Shadrach, Meshach and Abednego, to worship the image, regarding such an action as the most blatant idolatry ${ }^{2}$.

Thus the Christians had a striking precedent from the Old Testament when they were faced with the dilemma of compulsory worship of the emperor. Statues in gold and silver were those generally regarded as divine honours, and although many emperors forbade such images, in the first century Caligula, Nero and Domitian excluded themselves from this policy ${ }^{3}$. Distinction should be made between the cult-statues and the honorary statues - in actual fact, it was the ' $\alpha$ ' $\gamma \alpha \lambda \mu \alpha$ ' only which should have been regarded as blasphemous in Christian eyes.

Crimes against the imperial image as portrayed in sculpture, on coins or cameos, are attested throughout the first century, and disrespect to such likenesses was the equivalent of direct disrespect towards the emperor himself. It is for this reason that under Tiberius

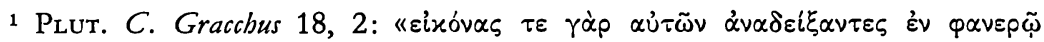

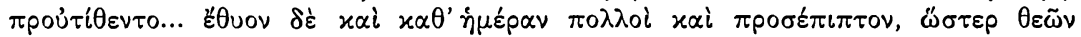

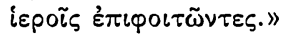

2 Dan. III 15.

${ }^{3}$ For further details concerning this point, cf. K. Scotr, The Significance of Statues in Precious Metals in Emperor Worship. TAPhA LXII (1931) p. 101. 
it was considered a crime to go to any place looked on as unclean while wearing a ring with the emperor's effigy carved on it, or even carrying a coin bearing the imperial portrait. Seneca recounts an episode when the ex-praetor Paulus was penalised for committing what was considered an unclean act while wearing a ring with a cameo representing Tiberius ${ }^{1}$.

Yet Tiberius showed himself less rigid than some of the senators; in the case of Lucius Ennius who, having melted down a silver statue of the emperor, had been summoned for the crime of treason, the emperor forbade the accusation ${ }^{2}$. There is not the same concern for the imperial statues under Tiberius as there was in the reign of Caligula, and when Tiberius showed irritation, it was not for a direct insult offered towards his image, but rather on account of the implications which he imagined he could read from an action. This is the case when Julia dedicated a statue of Divus Augustus and had her name engraved before that of Tiberius, which, so Tacitus tells us, caused him much irritation ${ }^{3}$.

References to statues of Divus Augustus abound in the texts and inscriptions, but even though, imperial claims for such honours were quite modest under Augustus and Tiberius. Tacitus interprets such statues erected during the reign of Augustus in a most ironical way, declaring that nothing was left for the gods in the way of divine honours, for the emperors wanted, like them, to be worshipped in temples by means of his images and like them to have flamines and priests for his worship ${ }^{4}$. The statement is not borne out by Dio who reports the reticence of Augustus to accept such honours; when the Senate and the people made contributions to set up statues

1 Seneca, De Benef. III 26, 1: «Cenabat Paulus praetorius in convivio quodam imaginem Tib. Caesaris habens ectypa et eminente gemma...»Cf. FurTwaENGLER, Die antiken Gemmen. Pl. L. 51. Also SuET. Tib. 58, 3: "nummo vel anulo effigiem impressam latrinae aut lupanari intulisse.»

2 TAC. Ann. III 70, 2: «L. Ennium equitem Romanum, maiestatis postulatum quod effigiem principis promiscum ad usum argenti uertisset, recipi Caesar inter reos uetuit..."

${ }^{3}$ Ibid. III 64, 2: "Neque enim multo ante, cum haud procul theatro Marcelli effigiem diuo Augusto Iulia dicaret, Tiberi nomen suo postscripserat... »

${ }_{4}$ TAC. Ann. I 10, 5: "Nihil deorum honoribus relictum, cum se templis et effigie numinum per flamines et sacerdotes coli uellet.» Tacitus also speaks of a statue of Divus Augustus, and a sanctuary consecrated to the Julian family at Bovilles, ibid. II 41, 1: «... sacrarium genti Iuliae effigiesque divo Augusto apud Bovillas dicantur.» 
in honour of their emperor in 11 B.C., Augustus refused to use these donations for this purpose and instead set up statues of Salus Publica, Concordia and Pax ${ }^{1}$.

Tiberius seems to have been loth to have too much personal honour and he forbade anyone to erect statues in his honour, or to display his portraits without his permission. Suetonius remarks that the only exception that he made was if these portraits were hung as ornaments, and not among the images of the gods ${ }^{2}$. This exception might very well be the loop-hole which Tiberius has been suspected of leaving in all his professions against personal honours.

Politically speaking, emperor-worship was not merely the means of providing a common bond for the empire, but Tacitus hints that on occasion it was used to take men's minds off unpleasant truths. In 28 A.D., the Frisians were victorious over the Romans, and the latter suffered severe losses, but both Tiberius and the Senate held the opinion that the interior state of the empire needed readjustment and that a war at this point would be undesirable. A diversion was sought in the imperial worship, and altars were set up to Clemency and Friendship, while, at each side, there were statues of Tiberius and Sejanus ${ }^{3}$. This does not minimize the fact that the omnipresence of the emperor was made manifest through his images and statues ${ }^{4}$.

It is well-known how excesses in the emperor-cult took place under Caligula and it is during this reign that the worship of the "statue of the beast» took on far greater proportions and became for the first time a menace to Jewish monotheistic beliefs. Suetonius points out sarcastically the extent to which Caligula went to provide for his own adulation and worship through the means of his statues, even sending to Greece for statues which far surpassed Roman craftsmanship in style and beauty, and he had the heads replaced by copies

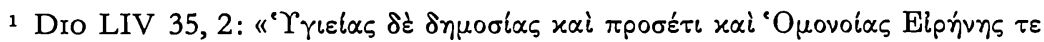

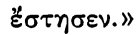

2 SuEt. Tib. 26, 3: «... prohibuit etiam statuas atque imagines nisi permittente se poni, permisitque ea sola condicione, ne inter simulacra deorum sed inter ornamenta aedium ponerentur.»

3 TAC. Ann. IV 74, 3: "Ita quamquam diversis super rebus consulerentur, aram Clementiae, aram Amicitiae effigiesque circum Caesaris ac Seiani censuere crebrisque precibus efflagitabant visendi sui copiam facerent." Statues of Tiberius in temples existed even during his lifetime, e. g. OGIS 583, p. 274 (on Cyprus

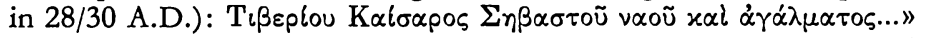

${ }^{4}$ Cf. S. Eitrem, Zur Apotheose. SO XV (1936) p. 112: «Die Bilder sind ein Zeugnis der Allgegenwart des Kaisergottes.» 
of his own. Among these statues (simulacra), one in particular was mentioned, that of the Olympian Jupiter ${ }^{1}$.

It would seem that Caligula set great store by giving the populace the opportunity of adoring the emperor, for having enlarged the wing of the Palatium as far as the Forum, he transformed the temple of Castor and Pollux into a vestibule. It was presumably in this vestibule that he placed the statues of the gods where they might be venerated by those entering or leaving the Palatium, and his own statue in the midst of those of the gods, underlined and encouraged the belief in the imperial divinity. Caligula's excesses in this field were noteworthy and Suetonius continues to stress the lengths to which the emperor went; Caligula even went so far as to consecrate a special temple to his own divinity, complete with 'flamines' and rare victims. The temple contained a life-sized statue of the emperor ${ }^{2}$.

At the same time, Caligula strove to safeguard his own position by keeping a close watch on any possible rivals who might be seeking to usurp his position. For this reason, he forbade the erection of the statue of any living person in any place without his knowledge ${ }^{3}$; this gave the emperor a two-fold control, for he could thus limit the number of statues of any one man and he could also foresee a rival's growth in popularity by the number of requests for the erection of his statue.

Philo gives a clear, if biased account of the reactions to Caligula's anti-Jewish policy, especially in Alexandria, where the Jews were simply a minority group. Caligula set great store by the fact that his deification had originated in Alexandria, a city which had much

1 Suet. Cal. 27, 3: «Datoque negotio, ut simulacra numinum religione et arte praeclara, inter quae Olympi Iovis, apportarentur e Graecia, quibus capite dempto suum imponeret, partem Palatii ad forum usque promouit, atque aede Castoris et Pollucis in uestibulum transfigurata, consistens saepe inter fratres deos, medium adorandum se adeuntibus exhibebat. " According to Dro (LIX 4,4), early in his reign, Caligula apparently forbade anyone to erect images in his honour... he afterwards changed his policy and ordered tempels to be erected and sacrifices to be offered to him as to a god... The same author relates how by 39 A. D., sacrifices were made to the Clemency of Caligula and on these occasions a golden image of the emperor was to be carried to the Capitol, and hymns were sung in its honour (Dro LIX 16,10).

${ }^{2}$ Suet. Cal. 22, 4-5: "Templum etiam numini suo proprium et sacerdotes et excogitatissimas hostias instituit. In templo simulacrum stabat aureum iconicum amiciebaturque cotidie veste, quali ipse uteretur.»

3 Suet. Cal. 34, 2: "Vetuitque posthac viventium cuiquam usquam statuam aut imaginem nisi consulto et auctore se poni.» 
influence in the world because of its size and position. Portraits of Caligula were placed in all the synagogues of the city; an action which the Jews naturally considered as blasphemous. In the largest and most important synagogues, a bronze statue of the emperor driving a four-horse chariot, was given a prominent position ${ }^{1}$.

Philo contrasts the action of the Alexandrians on behalf of Caligula with the singular lack of recognition of the benefactions they received during the reign of Augustus. Philo is probably praising Augustus to this extent because he wished to underline the differences between their lives and the recompense in honours which each received. It is pointed out that during the years of Augustus' rule over Egypt - forty-three in all - the Alexandrians never thought it necessary to make a single dedication in the synagogues, neither did they express their gratitudes by the usual honour of erecting statues of the emperor; there was not so much as a wooden image or a painting to bear witness to all that Augustus had done ${ }^{2}$.

While awaiting an audience at Dicaearchia, Philo received the news that Caligula had given orders to set up a colossal statue in the Holy of Holies in the synagogue named after Zeus himself ${ }^{3}$. Further on, Philo gives the motive for this action, which was 'known to the whole world'. Caligula's greatest ambition was to be regarded as a god by all his subjects ${ }^{4}$. The Jews had always enjoyed a privileged position in this question of emperor-worship and both $\mathrm{Au}-$ gustus and Tiberius respected the Jewish conscience and granted them the necessary concessions. However, this state of affairs would not satisfy Caligula, who could not accept the idea of a God greater than himself, and since the Jews refused to change their manner of worship, the emperor sought to inflict a punishment on them which would be severely felt, in the desecration of their temple. Josephus makes reference to Gaius' order for the erection of his statue in the Temple at Jerusalem, which was part of his policy in encouraging people to consider and hail him as a god. He mentions too the fact

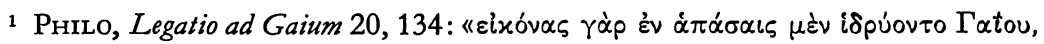

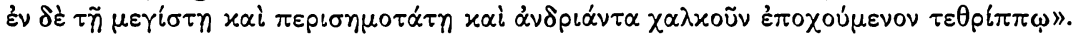

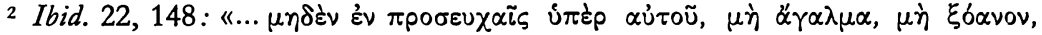

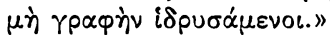

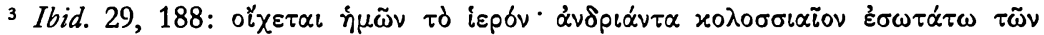

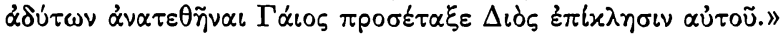

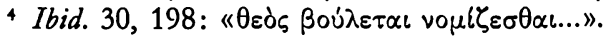


that Petronius was sent with an army to install the statues in the sanctuary; according to the account in the Jewish Wars, there seems to have been more than one statue involved, although in the 'Jewish Antiquities', Petronius is sent "to set up an image of Gaius in the temple of God.» The fact that an army was sent was a safety measure should the Jews have refused to accept the statues, for his orders were to put the recalcitrants to death and to reduce the whole nation to slavery ${ }^{1}$. Josephus here refers to three legions which set out from Antioch on their march to Judaea. In the parallel passage ${ }^{2}$, the same author refers to two legions only. As has already been noted, Philo states that Caligula ordered Petronius to take half of the Euphrates' army into Judaea, and since this army consisted of four legions at this time, the statement of Josephus is to be preferred ${ }^{3}$. Petronius met the Jews at Tiberias, and tried to convince them that all subject nations had erected statues of the emperor along with those of the gods in all their cities ${ }^{4}$.

Later, when Caligula was finally persuaded to abandon the idea of erecting his statue in the Holy of Holies, he nevertheless left the way open for the enemies of the Jewish race and religion to offend their religious sensibilities by making it legal for those from the country surrounding the capital to erect images or altars for sacrifices in honour of the emperor or of the imperial family ${ }^{5}$.

The Jewish reaction to this harsh policy was extremely strong, as was to be expected, for they threatened a mass revolt whereby they would kill their wives and children before finally committing suicide themselves; this they saw as the only solution in their attempt to reconcile two parallel claims, the respect due to their emperor and the obedience due to the Jewish laws; since these two were contradictory, there seemed no other solution than the drastic measure of a general suicide ${ }^{6}$.

Josephus gives further details of the Jewish reaction ${ }^{7}$ for, having

1 Jos. Bell. Iud. II 184-187.

2 Jos. Ant. XVIII 262.

3 Cf. Jenvish Antiquities, translated by L. H. Feldman. London, 1965, p. 157, note a.

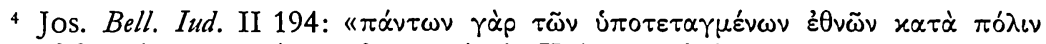

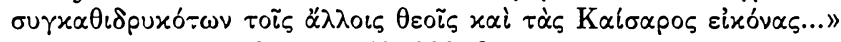

${ }_{5}^{5}$ PHILO, Leg. ad Gailum 42, $333 \mathrm{ff}$.

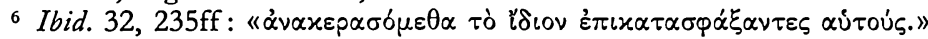

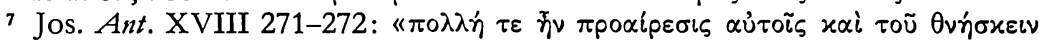

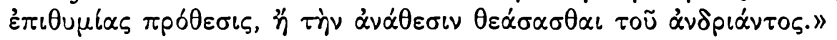


declared their willingness to die rather than accept the erection of a blasphemous image, the Jews fell on their faces, baring their throats as a sign that they accepted to be killed. They continued in this manner for a period of forty days ${ }^{1}$, and they neglected their fields even though it was seedtime and the fields were in danger of remaining fallow. Although the Jews were so adamant in refusing to give to Caligula what they considered was due to God alone, they accepted willingly the duty of praying for the emperor. In answer to Petronius' query: "Will you then go to war with Caesar?», the Jews replied that they offered sacrifice twice a day for the emperor and the Roman people.

In the letter of Agrippa to his emperor, he endeavoured to point out the significance of such an action in the eyes of pious Jews. The temple had never, since its foundation, admitted any images. God being invisible, it was impossible in Jewish eyes to perceive his presence by the senses and therefore any attempt to portray God in paintings or sculpture was considered blasphemous by believing Jews ${ }^{2}$. However, the emperor's bitter hatred of the Jewish race led him to take over the synagogues in each city and place his own statue in them; he even began a new project of altering the Temple in Jerusalem to a shrine to his own honour and glory, which would be named that of 'Gaius the New Zeus made Manifest" ${ }^{3}$.

Nero was the second emperor to encourage divine honours and although he did not continue the policy of Caligula towards the Jews, he permitted an enormous statue of himself to be set up in 67 A.D. at the request of the Augustiani. Since these Augustiani were a Neronian institution, it is likely that the statue was the idea of the emperor himself. The statue weighed a thousand pounds, and became the responsibility of the equestrian order to help defray the cost ${ }^{4}$. Dio mentions a similar statue set up for Commodus, which was made of gold ${ }^{5}$, so there is a possibility that the one of Nero was made of some precious metal, if not gold.

If that is indeed the case, then it would have been used directly

1 Fifty days, according to Jos. Bell. Iud. II 200.

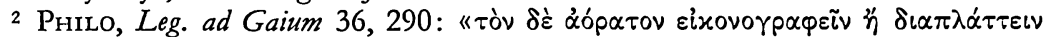

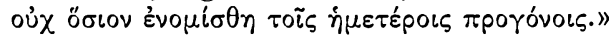

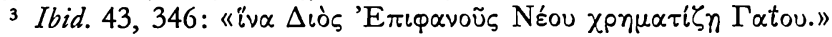

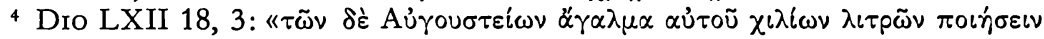
نं

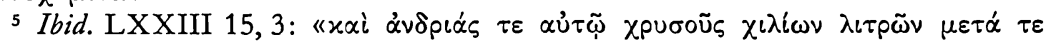

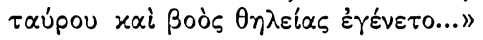


for cult-worship, and would fit in with the text of the Apocalypse, which speaks of «the statue of the beast which was wounded by the sword, and still lived ${ }^{1}$. Nor was this the only example; even allowing for Dio's exaggeration, this author declares that so many honours were voted to the emperor, that almost the whole of his empire was filled with his images in silver or in gold ${ }^{2}$.

After the murder of Domitian, the senators received the news with great rejoicing and ordered ladders to be brought in during the sessions so that the images of their hated ex-emperor could be thrown down on the floor ${ }^{3}$.

One of the better-known references to honour paid to the statue of an emperor is that found in Pliny's correspondence with the emperor Trajan ${ }^{4}$, where the offering of incense and wine to the images of the gods, which included the statue of the emperor himself, was the test of loyalty for any suspected of being Christians. There are other references to the statues of emperors to be found among Pliny's writings. In another letter ${ }^{5}$, he had asked permission of Trajan's father to remove several statues to his municipality. Owing to circumstances, Pliny had not been able to carry out his designs, nor was he able to build a temple in which to house them. Pliny, hoping for a leave of absence from the emperor so that he might settle his private affairs, introduced his request by asking permission to adorn the temple which was about to be erected, with the statue of Trajan as well. One feels that this was a prudent means of paving the way for a demand of thirty days' leave of absence from his post, since it was no doubt offered as a compliment to the emperor. Trajan, on his side, showed himself to be extremely cautious, and though he states that he had no wish to check any exterior manifestation of Pliny's loyalty and does not oppose Pliny's designs, he points out that he is loth to give encouragement to honours of this kind.

1 Apoc. XIII 14.

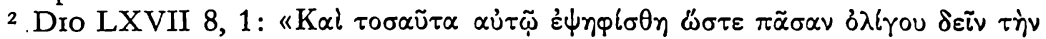

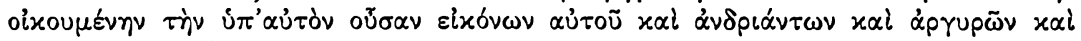
$\chi \rho \cup \sigma \tilde{\omega} \nu$ ह่ $\mu \pi \lambda \eta \eta \theta \tilde{\eta} \nu \alpha(\ldots)$

3 Suet. Dom. 23,2: «senatus adeo laetatus est, ut... clipeos... et imagines eius coram detrahi et ibidem solo affligi iuberet...»

4 Pliny, Letters X 96, see p. 79 note 4.

5 Ibid. X 8. 


\section{TWO CULT EXPRESSIONS PARALLELED IN IMPERIAL AND CHRISTIAN USAGE}

\section{The Notion of 'Ascension' as an Expression of Glorification}

Another aspect of the imperial cult which finds its parallel in the New Testament writings is that of 'ascensio'. The idea of Ascension was common to many primitive religions as an expression of the glorification of a human being after his death. The forms of attaining this glorification were varied, but all expressed the notion of passing from the human to the divine state, and the Ascension became an important symbol in the deification of an emperor. At this period, natural prodigies played a significant part in influencing the minds of men, who readily accepted such tokens as the symbolic expression of some reality. Even superficial reading on the imperial cult shows clearly the tremendous influence which natural phenomena had on the minds of men, and presumably the emperors made much of these so-called signs in their efforts to sway public opinion. These prodigies were used for various ends; to establish the deification of a member of the imperial family, to engender fear among the masses by the forecast of sinister events or to manifest the heavenly favour of the gods for the ruler.

It is remarkable that, on the whole, there is only infrequent mention of miracles for Augustus and the early emperors; the lengthiest is the account of the miraculous birth and early childhood of Augustus as given by Suetonius, a late account which finds no support from earlier sources and based on what were probably the most popular legends which developed gradually after the death of the first emperor. Suetonius relates how the mother of Augustus was said to have been visited by Apollo in the shape of a serpent in his temple, and the fruit of this union was the child who was later to rule 
over the vast Roman Empire and who was said to be the son of Apollo ${ }^{1}$.

A second group of miracles are given by Tacitus ${ }^{2}$ and refer to the early part of the reign of Vespasian, at a period when the turmoil of the years 68/69 A.D. was gradually receding from the minds and memories of men, and when the emperor needed some sort of heavenly approval to help him consolidate his position and win the support of the credulous. Such legends may have done more to capture the popular imagination and to establish the emperor in his position, than the various forms of the State cult. Insofar as these miraculous accounts translated an idea or a way of thinking, they were most important for the imperial cult. It is significant that these miracles of Vespasian originated in Egypt - that part of the Empire where men were greatly influenced by oracles and omens, and who were presumably more easily hoaxed than in the more sober West.

Vespasian's claims were aided by an ancient tradition according to which the empire of the whole world was to be under rulers coming from Judaea about this time ${ }^{3}$. Suetonius, no doubt, exaggerates when he gives the impression that all the East was in expectation of the event, but the predictions of the coming Messiah of the Jews had indeed reached the ears of the Wise Men of St. Luke's narrative. Of the vast numbers who would have heard the rumours of the coming Messiah, many would have interpreted them as did Suetonius, applying them to a pagan emperor.

1 Suet. Aug. 94, 4: "In Asclepiadis Mendetis Theologumenon libris lego, Atiam, cum ad sollemne Apollinis sacrum media nocte uenisset, posita in templo lectica, dum ceterae matronae domum irent, obdormisse; draconem repente irrepsisse ad eam pauloque post egressum; illam expergefactam quasi a concubitu mariti purificasse se.»

2 TAC. Hist. IV 81, 1: «Per eos menses quibus Vespasianus Alexandriae statos aestiuis flatibus dies et certa maris opperiebatur, multa miracula evenere, quis caelestis favor et quaedam in Vespasianum inclinatio numinum ostenderetur.» Tacitus interprets these miracles at Alexandria as a mark of the favour and sympathy of the gods for Vespasian. Cf. K. Scotr, The Imperial Cult under the Flavians. Stuttgart/Berlin, 1936. Chap. I. Vespasian's Auctoritas et Maiestas. On p. 1, the author points out that Vespasian could not claim divine descent, and these miracles established a form of mystery which would have proved useful to him during his reign. This is mentioned by Suetonius, Vesp. 7, 4: "Auctoritas et quasi maiestas quaedam ut scilicet inopinato et adhuc novo principi deerat; haec quoque accessit."

${ }^{3}$ SuEt. Vesp. 4, 9: "Percrebruerat Oriente toto vetus et constans opinio esse in fatis ut eo tempore Iudaea profecti rerum potirentur.» 
It is clear that the Romans of the early Empire interpreted the various prodigies of nature as being signs from which they could judge whether the actions of their imperial leaders were to be crowned with success or failure. These omens also served to underline certain happenings, the acceptance of which would strengthen the position and authority of the emperor. Most emperors, whilst claiming to ignore such phenomena and the prestige they were thus accorded, realized that they could be a powerful means of propaganda, and generally did nothing to discourage them.

Appian states definitely that both Alexander and Caesar despised the prodigies relating to themselves, but that they did not deal harshly with the soothsayers who predicted their deaths ${ }^{1}$. However, if they did not persecute the extremists who went so far as to predict the death of their rulers, it is unlikely that action was taken against those who promulgated the prodigies, however much they were disliked.

Among some New Testament commentators, it became fashionable to look on the miracles of Christ in the same light as these 'propaganda aids' and as a reflection of the cult which grew up around the person of Christ. It is true that there are many seeming parallels between the circumstances of Christ's birth and life, and those accounts of similar occurrences in the works of pagan writers, as if the latter were nearing the great and eternal truths of the life on earth of the 'Word made Flesh' without grasping the fulness of truth which was only to be found in the teachings of the leader of the despised Christian sect. I do not intend going into the whole question of miracles; brief mention has been made on the question of healing in connection with the title of 'Saviour'. One aspect of the miraculous, however, will be dealt with here and that is the notion of ascension and its significance for the men of this epoch. There is no doubt but that men were particularly influenced by the notion of life after death and glorification at this period; an indication of the influence of the Oriental religions, whose popularity was on the increase in the first century A.D.

The translation of the idea of an ascension into human terms was generally simple and to the point - heaven was accepted as

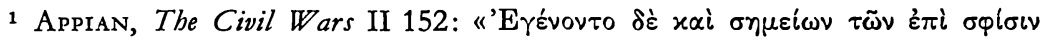

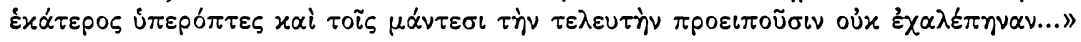


being above the earth and the various methods of reaching heaven in the ancient myths were often naïve in the extreme - in a chariot, on the back of an eagle or symbolized as a comet. Gradually the actual bodily ascension began to take a less prominent place; it was the spirit of the dead man which was believed to have taken its place among the gods, the accepted deities of each particular race of people. This idea of heaven above the earth was current, not only for the pagan Romans, but for the more primitive peoples in every civilization; in Jewish history, there is the well-known episode of Elias, disappearing into Heaven in a fiery chariot ${ }^{1}$. We are told that having crossed the Jordan, Elias and Eleseus continued on their way, until they were separated one from the other by a chariot and horses of fire (the fire being a symbol of glorification) and Elias was taken up into the heavens in a whirl-wind, which depicts the movement of ascension. The text tells nothing of the place to which Elias was transported; no details are given and the only sure point was that he was seen no more on earth ${ }^{2}$.

It is necessary to look more closely at the various interpretations of apotheosis designed, no doubt, to impress the idea on the minds of people, for natural phenomena served as a means of drawing men's attention to some great event.

The idea of an ascension played an important role of propaganda for the general masses in the early empire and the minds of men were formed to accept a sign such as a comet or the upward flight of an eagle for the final mark or proof of the glorification of the emperor, as he took his place among the gods who were already receiving the worship of the people. There was a definite feeling that the dwelling-place of the gods was above the earth, among the mysteries of the universe which seemed so much more impenetrable two thousand years ago than it does today. The vastness of the firmament fostered these primitive ideas about the heavens, which hold little conviction in this age of space-travel and sophistication of thought. Whether or not the imperial ascensions were believed and accepted by the majority of Roman citizens is a matter of some uncertainty; but the very fact that the symbol of the ascension was noted and commented upon presupposes that it had its value in

1 II Kings II 9-12.

2 Cf. A. Médébielle, Les Livres des Rois. Paris, 1949, p. 701 f. 
establishing the emperor in his deified position, at least for the less intellectual.

Suetonius makes this quite clear when he writes that Caesar was numbered among the gods, not by the formal act of deification pronounced by the Senate, but by the profound conviction of the populace ${ }^{1}$. In other words, it was the people's conviction which made the deification of the emperor a reality, in a certain sense; the actual senatorial decree would have meant nothing on its own.

The notion of the emperor's soul ascending to heaven in the form of a comet was received with seeming credulity. One of the most famous ascensions in Roman history was that found in the legend of Romulus ${ }^{2}$. The disappearance of Romulus on the Nones of July, leaving no account of his death, led to suspicion and calumny; it would seem that the enemies of Romulus used this lack of knowledge for their own ends to spread adverse rumours among the people. Plutarch is insistent on the lack of any trace - no portion of Romulus' body was found, and not so much as a fragment of clothing remained to give a clue as to the whereabouts of his body, or the death he had undergone.

One theory was that the senators had attacked and killed him in the sanctuary of Vulcan, and having killed him, dismembered his body, dividing it into sections small enough to be hidden in the folds of the robes of each senator until he could dispose of it. Another belief was that Romulus was holding an assembly outside the town when a tremendous hurricane hit the spot and an eclipse of the sun caused the sky to darken until it seemed like night. These prodigies created a great fear among the people and they fled, leaving the senators grouped together. When the hurricane had passed, the people re-assembled at the same place, only to find that Romulus had disappeared. The senators were loth to allow any form of enquiry, but they ordered all to honour Romulus who had been taken up to the gods, and, having been a generous king in his lifetime, would from this moment be a propitious god. According to Plutarch, the majority of those present believed these words and went away, full of joy and hope, adoring the new god.

1 SUEt. Jul. 88, 1: «... atque in deorum numerum relatus est, non ore modo decernentium, sed et persuasione volgi.»

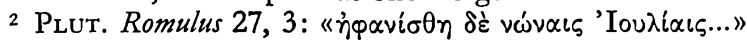


But there were the less-credulous who gave anxiety to the patricians by their accusations that the latter had attempted to hoodwink the people by telling them 'stupid stories', and had assassinated the king with their own hands. To counteract these accusations, Julius Proculus swore under oath that he had seen Romulus in a vision, brilliant and glorious, who spoke of having returned to the heaven from whence he had come ${ }^{1}$. Tertullian sees this ascension of Romulus as a faint shadow of the reality of the glorification of the Son of God; having given a description of the Ascension of Christ, step by step, he says that Jesus was caught up into heaven more truly than any Romulus as is told in the tale of Proculus ${ }^{2}$. No mention is made of a comet in this context, and it is probable that the vision was of the person of Romulus and not of a symbol of his ascent, judging from Plutarch's account.

Perhaps the most famous comet described in Roman literature and which was depicted in the various art-forms of the time, was the comet that appeared at the death of Caesar in 44 B.C., and which is immortalized in the famous lines of Shakespeare:

"When beggars die, there are no comets seen,

The heavens themselves blaze forth the death of princes ${ }^{3}$.

This comet appeared on a number of successive evenings in the North, and although some claimed that it foretold merely the usual occurrences, this interpretation was not popular with the majority of people, looking on it as a sign of the immortality of Caesar, who had been received among the gods under the form of a star ${ }^{4}$. Because of the force of popular opinion, Octavian was able to take advantage of this further prop to his claim of divinity for his adopted father,

1 Plut. Rom. 28, 1-2.

2 Tert. Apol. 21, 23: "Cum discipulis autem quibusdam apud Galilaeam, Iudaeae regionis ad quadraginta dies egit docens eos quae docerent. Dehinc ordinatis eis ad officium praedicandi per orbem, circumfusa nube in caelum est receptus, multo verius quam apud vos adseverare de Romulo Proculi solent.»

3 Shakespeare, Julius Caesar II 2, 30.

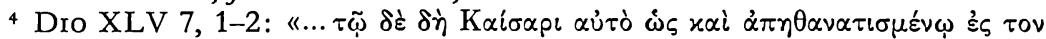

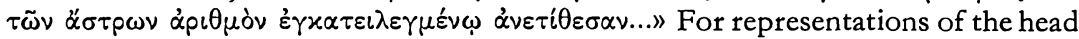
of J. Caesar with a star above, cf. H. Mattingly \& E. Sydenham, The Roman Imperial Coinage. London 1923, p. 73, nos. 141 and 142, Pl. I. 13 (Pl. III). 
and to encourage this belief, he set up a bronze statue of Caesar with a star above his head in the temple of Venus ${ }^{1}$.

Suetonius shows that the people were ready enough to believe that the comet was the soul of Caesar ascending into heaven, and Octavian showed a shrewdness in promoting this belief. According to Suetonius, the comet appeared about the eleventh hour and shone for seven consecutive days during the first games which were celebrated in honour of the dead Caesar ${ }^{2}$.

Both Seneca and Dio make reference to comets seen at the death of Augustus, but these are more as general 'signs' than the symbol of the soul of the emperor ascending in the form of a comet. Seneca, in his discussion of certain natural phenomena in the heavens which puzzled men throughout the ages, writes of the prodigies occurring at the death of Augustus, and later on, at the death of Germanicus and the condemnation of Sejanus. Seneca is writing this account at first hand, as if he had been an eye-witness of these presages, for he describes the meteors as if he himself had seen them: "We saw a similar portent (a huge ball-shaped flame) about the time of the death of the late Emperor Augustus. We again saw one when Sejanus was executed. A warning of this kind preceded the death of Germanicus» ${ }^{3}$.

This reference to the comets seen shortly before the death of Augustus is also mentioned by Dio ${ }^{4}$, where he remarks that a number of omens appeared about the same time, all of which pointed to the death of Augustus, and although they appeared while the emperor was still alive, people later recognized their significance. Apart from a total eclipse of the sun and the illusion that fiery embers were falling from the sky, a number of blood-red comets were seen.

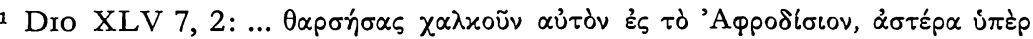
$\tau \tilde{n} \varsigma$ $x \varepsilon \varphi \alpha \lambda \tilde{n} \varsigma$ है $\chi 0 \nu \tau \alpha$, है $\sigma \tau \eta \sigma \varepsilon v . »$

2 SUET. Jul. 87, 2: "Siquidem ludis, quos primos consecratos ei heres Augustus edebat, stella crinita per septem continuos dies fulsit exoriens circa undecimam horam, creditumque est animam esse Caesaris in caelum recepti.»

3 Seneca, Naturales Quaestiones I 1, 2 (Questions Naturelles, Tome I, trans. Paul Oltramare, Paris, 1929: "Vidimus circa divi Augusti excessum simile prodigium. Vidimus eo tempore quo de Seiano actum est, nec Germanici mors sine denuntiatione tali fuit. » Cf. RE III A 2 (1929) col. 2445.

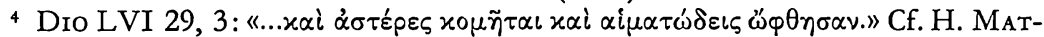
TINGLY \& E. Sydenha M, RIC Pl. V 78 (also, p. 103, 1) which shows the head of Augustus, and above, a star. P. 110, 46, shows the radiate head of Augustus, above a star. Cf. p. 116, 9. 
Dio deals more fully with the 'ascensio' of the emperor, giving certain details to supplement the account given by Seneca; for example, the name of the praetor is given and the amount of money bestowed on him by a grateful Livia for his timely testimony. Dio records the bestowal of a million sesterces by Livia upon a Numerius Atticus, a senator and ex-praetor, because he swore that he had seen the soul of Augustus ascending to heaven «after the manner of which tradition tells concerning Proculus and Romulus» ${ }^{1}$.

Suetonius does not state expressly that the spirit of Divus Augustus was seen ascending to heaven under the form of a comet - in very general terms, he relates how a former praetor swore he had seen the spirit of the dead emperor going up to heaven after the cremation ${ }^{2}$. Not only was this symbolic ascension attested after the death of Augustus, but also for lesser members of the imperial family; Seneca reports a similar visible ascension for the sister of Caligula, Julia Drusilla ${ }^{3}$. The appearance of a comet was also one of the principal signs at the death of Claudius, together with the falling of a thunderbolt on the tomb of his father, Drusus ${ }^{4}$.

The star of apotheosis is depicted in various contemporary portraits and particularly on coins of this period; the star appears on coins from 17 B.C. onwards ${ }^{5}$. One particularly noteworthy example in sculpture is found on the relief of Mars Ultor, part of

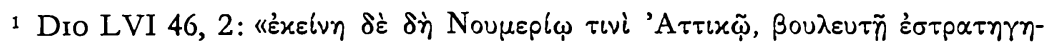

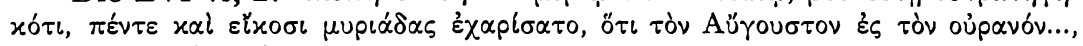

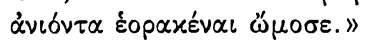

2 Suet. Aug. 100, 7: «Nec defuit vir praetorius, qui se effigiem cremati euntem in caelum uidisse iuraret.»

3 SEN. Apocolocyntosis I 3: «ex quo in senatu iuravit se Drusillam vidisse caelum ascendentem..."

${ }^{4}$ SuEt. Claud. 46, 1: «Praesagia mortis eius praecipua fuerunt: exortus crinitae stellae (quam cometem vocant), tactumque de caelo monumentum Drusi patris...».

${ }^{5}$ For a selection of such coins, cf. C. H. V. Sutherland, Coins in Roman Imperial Policy, London, 1951, p. 107. Pl. X. 1: a denarius from Lugdunum, reverse - Divus Augustus with two stars (A. D. 37-38). Also, H. Matringly, Coins of the Roman Empire in the British Museum, Vol. I. London, 1923. p. CxLIV and Pl. 27, 1-4. Both these authors remark that the features are those of Tiberius, not Augustus. The probable reason is that Caligula, having made the funeral oration for his predecessor, asked the Senate tentatively about deification for Tiberius (Dio LIX 3,7). When the Senate showed no enthusiasm for this project, the idea was dropped and the title was hurriedly changed on these coins to Divus Augustus. The two stars are probably supposed to represent the two 'Divi' - Augustus and his successor. 
an altar found at Carthage and now in the Algiers Museum. In the centre stands Mars Ultor wearing a high-plumed helmet, with his left hand resting on a shield. To his right is Venus Genetrix who is being offered a sword by a cupid appearing from under her drapery. On the left of Mars Ultor is a figure generally accepted as Divus Julius, for a cavity in his head suggests that originally there was a star of apotheosis affixed in this position ${ }^{1}$.

The star is not bound up solely with the idea of Ascension, for in the ancient world of the East, and in particular, in Babylon and Egypt, one of the many terms applied to rulers was that of a star which is the figure of kingly glory. In the sense that the ruler was thought to be divine, or at least worthy of divine honours, it is not too far-fetched to see that there could be a connection between these two themes. However, it is quite another aspect of stars or comets as illustrations in ancient religion; the term finds its parallel in Christian literature in the Apocalypse, where Christ is portrayed as the morning star: "I, the bright star of the morning» ${ }^{2}$. This statement would have meant a great deal to a Jewish Christian of the first century, and would have recalled to his mind many memories, for to give a man the title of «star of the morning" would equate him with the great heroes of the pagan world, and even with the gods. Moreover, there is the well-known Messianic prophecy: «A star from Jacob takes the leadership» ${ }^{3}$; this would have a strong effect on the minds of men of the time, even those who were not followers of the Jewish religion; the tradition of the Magi at the birth of Christ shows that these Gentiles were obviously conversant with this text, and were prepared to see in the star which had appeared, a sign that a great ruler had been born at Bethlehem.

The image of Christ in the Apocalypse is prefigured by Isaias, when he gives the king of Babylon the title of Morning Star ${ }^{4}$. The Babylonian king wanted to take his place with the gods above the

1 Cf. S. Gsell, Les Statues du Temple de Mars Ultor à Romo. RA XXXIV 1899) p. 37 ff. Also, CAH Vol. of Plates, IV. 1934, p. 136b.

2 Apoc. XXII 16. Cf. W. BARCLAY, The Revelation of Jobn, Edinburgh, 1959, p. 292.

3 Num. XXIV 17.

${ }^{4}$ Is. XIV 12-14: «... qui dicebas in corde tuo: In caelum conscendam, super astra Dei exaltabo solium meum... ascendam super altitudinem nubium, similis ero Altissimo.» 
firmament: "You who used to say to yourself, I will climb up to the heavens and higher than the stars of God, I will set my throne... I will climb to the top of the thunder; I will rival the Most High.» In this context, the star has another implication than the one which figured in the imperial cult as one of the ascension-symbols, yet there is common ground between the two, for here again, there is the same inference that the 'dwelling-place' of God was beyond the stars, and it was a like conception of the gods of the Romans being above the earth which inspired the accounts of the imperial ascensions. The consecration was the official act of deification after the death of an emperor, yet this in itself was of little importance if the general rank and file were not convinced; also the attitude of the succeeding emperor seems to have been taken into account, at least by Velleius Paterculus, who declared that Tiberius deified his father, not by an act of his imperial authority, but by his attitude of reverence towards his father; he did not merely give him lip-service by calling him a god, but he made him one in fact ${ }^{1}$.

Subjects of apotheosis were popular in first century art, where they were used as a powerful means of propaganda for imperial cult. Cameos were particularly popular for this end and two of the finest examples which have come down to us depict such scenes of glorification. The Gemma Augustea, a large cameo in the imperial collection in Vienna, illustrates clearly the notion of an ascension having taken place ${ }^{2}$. It is divided into two scenes, of which the upper scene is of greater interest for this subject. Here Augustus and the goddess Roma form the central group, but there is a wide diversity in the interpretations of their roles, as well as the identification of the remaining figures. While some commentators make a strong link between the two scenes, trying to date the cameo to an actual

1 Velleius Paterculus, Roman History II 126, 1 (LCL London, 1955, trans. F. W. ShIpley): "Sacravit parentem suum Casar non imperio, sed religione, non appellavit eum, sed fecit deum.»

2 Cf. A. Furtwaengler, Die antiken Gemmen. Amsterdam/Osnabrück, 1965 (1900) Vol. II, pp. 257-258. Pl. LVI. CAH Vol. of Plates IV p. 156. G. Rodenwaldt, Kunst um Augustus. Berlin, 1942, pp. 52-53. Pl. 33. L. Curtius, Ikonograpbische Beiträge zum Porträt der römischen Republik und der Julisch-Claudischen Familie. RM I(1948) p. 53 ff. J. Charbonneaux, L'art au siècle d'Auguste. Lausanne, 1948, pp. 84-86. E. WiLl, Sur quelques figures de la gemma augustéenne. Latomus XIII (1954), p. 597 ff. Th. Kraus, Das römische Weltreich. Berlin, 1967, p. 283. Pl. $384 \mathrm{~b}$. 
historical event ${ }^{1}$, others are of the opinion that the artist had no specific victory in mind, but created the scene on the cameo merely to glorifiy the imperial family, and to underline its internal hierarchy.

Setting aside all theories irrevelant to the theme of Augustan apotheosis, brief mention will be made of the arguments supporting this aspect. Curtius is of the opinion that the upper scene takes place in heaven, and that Augustus is depicted as Jupiter. He also notes that the chariot is that of an apotheosis and confirms this opinion that it could not be of the sort used for celebrating a victory, as Charbonneaux, Gagé and others wish to believe. If we follow this opinion, we see Augustus here represented as a god, being crowned with laurel leaves by a figure who is generally supposed to be a personification of Oikumene, the inhabited world. He is seated beside the goddess Roma, and above his head is represented the sign of Capricorn, under which Augustus was born or conceived. Beneath his seat is an eagle, the symbol of Jupiter. Tiberius approaches in order to pay homage to him whom he believes is the fundamental source of his victory. In the lower panel, one sees Roman soldiers in the act of mounting a victory in the presence of captive barbarians.

Another cameo which aims at the glorification of the imperial family, living and dead, is the Grand Camée de France ${ }^{2}$. Like the Gemma Augustea, there are two scenes on the Grand Camée, the higher representing a view of heaven and earth, while the lower scene depicts the captive Germans and Parthians. In the centre, Tiberius is identified with Jupiter with the attributes of lituus and sceptre; he is wearing the aegis which covers his legs. Livia as Ceres is seated on his left, while Tiberius offers the lituus to a young warrior who is generally identified as Germanicus. Between them stands a figure who is possibly the mother of Germanicus, Antonia. The small boy is probably Caligula, the youngest son of Germanicus, beside whom is the wife of Germanicus, Agrippina the Elder. Behind the throne is the Younger Drusus with his wife Livilla, who is

1 I.e. one of Tiberius' victories over the barbarians, 7 B. C. or 14 A. D.

2 A. Furtwaengler, Die antiken Gemmen. Pl. LX. Vol. II, pp. 268-271. J. Gagé, La Victoria Augusti et les auspices de Tibère. RA XXXII (1930) pp. $19 \mathrm{ff}$. CAH Vol. of Plates IV, p. 156. J. Charbonneaux, L'art au siècle d'Auguste, pp. 86-89. Pl. 85. 
pointing upwards towards the winged horse, a symbol of apotheosis, on which rides Germanicus who died in the East in 19 A.D.

The eagle came to take an important place in the imperial cult, for it was linked specially with the notion of 'ascension' - the bird which flew up from the earth, higher and higher towards the sun, captured the imagination and symbolized the ascent of the emperor's soul to the heavens to take its place among the gods. The idea of the emperor ascending to the heavens on the back of an eagle was borrowed from the Oriental belief that the eagle was the bird of the sun-gods, the Baals, and its upward flight suggested the ascension of the ruler who was about to take his place with the gods. As a development in the imperial cult, the practice grew up of fastening an encaged eagle to the top of the funeral pyre of the dead emperor, which, on its release would bear aloft to the heavens the emperor's soul ${ }^{1}$.

Dio makes a direct allusion to this practice when describing the funeral of Augustus. He notes that the centurions followed the decree of the Senate in taking torches and lighting the pyre from beneath. An eagle was released as the pyre itself was consumed, which encouraged the belief that the soul of the emperor was borne to heaven ${ }^{2}$. The eagle came to be common in imperial art, and the apotheosis of emperors is suggested by their representation in

1 Cf. Fr. Cumont, Astrology and Religion among the Greeks and Romans. London, 1912, and Etudes syriennes. Paris, 1917, pp. 35-118. In the latter work, the author discusses the origin of the eagle as a symbol of apotheosis. He gives an example of a Christian work where this pagan symbolism is converted to Christian usage. Cf. Fr. Cumont, Recherches sur le symbolisme funéraire des Romains, Paris 1942, pp. 97, 154, 240, 357, 437, 458; Lux Perpetua, Paris 1949, pp. 294 ff., 324. In the Acta Andreae et Matbiae, Ch. 17 (Acta Apostol. Apocrypha) the disciples of these two apostles tell of their ascension, when, during their sleep, eagles came down from heaven and flew up with their souls to paradise. When they awoke, their souls were brought back in the same way. A. RoEs, L'aigle psychopompe de l'époque impériale. Mélanges Charles Picard II, 1948, pp. 881-891, gives examples of figures on the backs of winged creatures from Classical Greek art. This author maintains that a Babylonian origin of Syrian figures of apotheosis would be too remote. The same author writes of the eagles as a representation of apotheosis in L'aigle du culte solaire syrien, RA XXXVI (1950) pp. 129-146. At the end of this article, the author poses a final question - was the idea of the ascension of a king the invention of the Chaldean priests in the Hellenistic period or did it have a Persian origin? (p. 45). Cf. H. Jucker, Auf den Scbwingen des Göttervogels. JBM XXXIX and XL (1959-60), pp. 266-288.

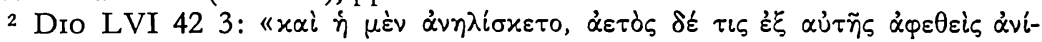

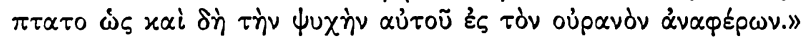


sculpture, on coins and on cameos ${ }^{1}$. The emperor or empress concerned is usually depicted on the eagle's back, or occasionally on that of a peacock.

On the reverses of coins, the eagle occurs in various forms, and, with the legend 'consecratio', it is obviously a symbol of apotheosis. Perhaps the most expressive is the type with the eagle bearing the emperor on its back, its wings outstretched in its upward flight. This type of reverse becomes popular under Antoninus Pius, where several coins depict the apotheosis of Faustina ${ }^{2}$.

The same type is found on the reverse of coins in honour of Divus Hadrianus and Divus Marcus. The reverse of an undated aureus of about 138 A.D. shows an eagle with wings spread, flying upwards and bearing Divus Hadrianus on its back. The Divus is holding a sceptre and his mantle is blown up around his head ${ }^{3}$. The Divus Marcus type is very similar; its probable date is 180 A.D. Here again, the eagle is soaring upwards, holding a thunder-bolt in its claws. Divus Marcus is being borne upwards into glory as he is framed between the eagle's wings, holding a long sceptre in his left hand ${ }^{4}$.

This particular image of apotheosis is not found on coins for the emperors of the first century, but it is found on cameos for Nero, and possibly Germanicus. The latter is a well-known cameo in the Bibliothèque Nationale, and it is known as the 'Apotheosis of Germanicus' 5. Whether or not the person on the back of the eagle

1 For a selection of such coins, cf. C. H. V. Sutherland, Coinage in Rom. Imp. Policy p. 207 \& Pl. IX 12; p. 32 \& Pl. I 15. H. Mattingly, E. Sydenham RIC p. 90, no. 357: Aes from Lugdunum. Reverse: eagle with spread wings. P. 95 \& 105: Eagle on globe - popular in Gaul (Pl. IV \& Pl. V).

2 For examples of this type: H. Matringly BMC (Ant. Pius) IV. nos. 1424, 1425 (Pl. 34, 9), 1426, 1427, 1428 (PL. 34, 3.). For a variant of this type, Faustina is carried to heaven by a peacock, cf. P. L. StrAck, Die Reicbsprägung zur Zeit des Antonius Pius. Untersuchungen zur römischen Reichsprägung, Teil III. Stuttgart, 1937, no. 1237. (Pl. VI).

${ }^{3}$ H. Mattingly BMC Vol. IV. no. 32. Pl. I. 15 (PL. VII).

4 Ibid. no. 394; 395, pl. 101, 6. (Pl. VIII.

5 J. Bernoulli, Die Bildnisse der römischen Kaiser. Berlin/Stuttgart, 1886. On p. 234, the author puts forward the argument that Germanicus never received deification, and suggests Augustus, Claudius or Trajan in his place. Cf. also, J. H. Middleton, The Engraved Gems of Classical Times. Cambridge, 1891, p. 61. E. Babelon, Catalogue des Camées Antiques et Modernes de la Bibliothèque Nationale, Paris, 1897, pp. 137-140. Pl. XXIX, no. 265. - G. Charles-PiCard, L'art romain. Pl. X, p. 177. The author underlines how the art of engraving stones, which 
is in fact Germanicus, has never been finally established, but he is obviously an emperor or a member of the imperial family. The male figure is seated on the back of the eagle with his head turned towards the left. In his right hand, he is carrying a lituus and in his left, a double cornucopiae. He is about to be crowned by a Victory, which is holding a wreath in her outstretched hands. The composition is typical of the imperial apotheosis as found on second century coins.

Another cameo depicting a similar scene of consecration is in the Library of Nancy ${ }^{1}$. This time it is Nero who is seated on the back of an eagle, holding a cornucopiae in his left hand, while a Victory stands on his right hand. The eagle is a particularly fine specimen; the position of its body and wings gives the bird an arched effect, as if its whole being were taut and poised, ready for its flight upwards on its sacred mission.

These illustrations of apotheosis which depict the emperor on the back of an eagle, are perhaps the most powerful in translating the notion of 'ascensio' into a concrete yet highly suggestive form. Yet the eagle appears in other less-striking attitudes, though still in the role of symbolizing deification; for example, the head or bust of the emperor, with a bird, probably an eagle, flying upwards, but separated from the figure of the emperor. There is no question of the emperor being actually seated on the back of the eagle, yet the symbolism is clear. This type may be seen on a cameo in Copenhagen ${ }^{2}$; the head of the emperor, possibly Augustus, is crowned with a wreath, while below the small figure of an eagle is flying upwards. The idea is the same as in the previous examples, though it is now simplified and less stylized. This type is also found on coins issued during the lifetime of an emperor - for example, some coins of Trajan show a bust of the emperor above the figure of a flying eagle ${ }^{3}$. This illustration is not found in Rome, which bears out the fact that divine honours or implications of divinity were received in the East during the lifetime of the emperor, which would not be tolerated at Rome.

received such attention during the first century, was used largely to further imperial propaganda.

1 A. Furtwaengler, Die antiken Gemmen. Vol. III, p. 324, fig. 168.

2 P. Fossing, Catalogue of the Antique Engraved Gems and Cameos. Copenhagen, 1929 , p. 177 , no. 1199 . Also, 1202-3.

3 H. Mattingly BMC. Phoenicia, 11; 12; 13; 16; 20. (Trajan) 1930 Nineveh. $8 ; 12 ; 30 ; 31$. 
A further development along the same lines are the portraits of three members of the imperial family over the outstretched wings of an eagle ${ }^{1}$. This coin is similar to a coin from Alexandria which has the heads of three divinities - a small statue of Harpokrates between Serapis and Isis ${ }^{2}$. The closeness in style shows how such illustration on coins would underline the divine aspect of the emperor and members of his house.

Both the comet and the eagle play an important role as a means of impressing the people of the emperor's divine status, particularly since the 'ascent' was visible to all. It was not always so easy to ascertain the manner of ascension in the case of Drusilla, the sister of Gaius, who was declared worthy of divine honours in all the cities and she received the name of Panthea. A senator, Livius Geminius, declared on oath that he had seen Drusilla ascending to heaven and conversing with the gods ${ }^{3}$. This declaration he made with great solemnity, calling down destruction upon himself and his children if his statement were not true, but the effect of his words are lessened somewhat by the additional remark that the senator received a million sesterces for his pains.

The idea of the ascent of the souls of the members of the imperial house, and the various symbols illustrating this theme, became more part of imperial propaganda and hence took on an increasingly meaningful place in late imperial thought and expression. In its late form, the central thought becomes more important than the stylistic perfection ${ }^{4}$.

A remarkable ivory panel from a diptych in the British Museum depicts various symbols of apotheosis which had taken their place in the thought and art of this period. Although late in comparison with the other monuments that have been considered ${ }^{5}$ a closer glance at this ivory would perhaps sum up the previous considerations

1 BMC Cremna, 1965, 12-4-1.

2 BMC Alexandria, 749.

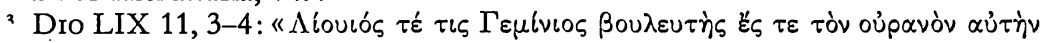

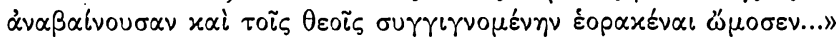

4 E. Kitzinger, Early Medieval Art in the British Museum. London, 1963, p. 13, states that this type of composition "is meaningless without a spectator.»

5 O. M. Dalton, Catalogue of Ivory Carvings of the Christian Era, London, 1909 , p. 2 , dates it in the early fourth century, because there is "no trace of the 'contabulatio' which became general during the fourth century.» Kitzinger, Early Med. Art. p. 13, dates it about the end of the fourth century (PL. IX). 
more concisely than a number of vague terms. This panel shows the apotheosis of an emperor, and it is likely that the second panel, now lost, illustrated a similar scene of apotheosis for an empress, and not an 'adventus-scene' as has been recently suggested ${ }^{1}$.

This panel is particularly significant because it contains several symbols of deification in the one representation. In the lower part, a bearded figure is seated on a triumphal car, holding a long sceptre in his left hand and a sprig of laurel in his right. It is not certain whom this figure represents, although Antoninus Pius is perhaps the most likely; the most recent interpretations have favoured Julian the Apostate, due to the presence of Sol Invictus and that of the elephants, seen as the symbols of the Eastern campaigns ${ }^{2}$.

The car is drawn by four elephants with four men on their backs. Such a quadriga was among the divine honours offered to a Divus; Suetonius speaks of how Claudius allowed a car drawn by elephants for Livia in the 'circensis pompa' similar to that which had been decreed for Augustus ${ }^{3}$. Illustrations of such scenes are found on coins; the reverse of an aureus of Nero ${ }^{4}$ shows a chariot drawn by four elephants. Divus Augustus and Divus Claudius are seated on two chairs; both are radiate. Augustus holds a patera in his right hand and a sceptre in his left, while Claudius holds an eagle-tipped sceptre in his right hand.

A similar scene shows Faustina the Elder receiving the same honour. She is seated on a throne drawn by two elephants and she is holding two corn-ears in her right hand and a vertical torch in her left ${ }^{5}$. As a symbol of eternity, the presence of elephants is most fitting on this panel of apotheosis.

1 A. St. Clair, The Apotheosis Diptych. The Art Bulletin XLVI(1962), p. 207.

2 Various interpretations are given in the following books: A. MASKELL, Ivories. London, 1905, p. 60 favours Marcus Aurelius Romulus. H. Graeven, Heidnische Diptychen. RM XXVIII (1913), pp. 198-304, sees it as the consecration of Constantius Chlorus. R. Delbrück, Die Consulardiptychen, Berlin/Leipzig, 1929. No. 59, pp. 227-230 gives Antoninus Pius as his choice. The following authors propose Julian the Apostate as the deified emperor in this diptych: R. Herzog TTZ XIII (1938) p. 116 ff. A. Alföldr, Die Kontorniaten. Leipzig, 1943, I, p. 43. K. WesseL, Eine Gruppe oberitalischer Elfenbeinarbeiten. JdI LXIII/ LXIV (1950), pp. 143-146. A. St. ClaIr, The Apotbeosis Diptych, p. 205.

3 Suer. Claud. 11, 4: "Aviae Liviae divinos honores, et circensi pompa currum elephantorum Augusto similem decernenda curavit.»

${ }^{4}$ BMC Nero, no. 7. Pl. 38, 4. Cf. also no. 8. Pl. 38, 5.

5 BMC Ant. Pius, no. 1434. Pl. 35, 1. 
In the centre of the panel is a draped funeral pyre, formed like three steps where from the topmost, a fourhorse chariot is about to take off for the heavens, driven by a beardless youth, whose cloak is swept upwards forming an arc above his head, and giving the impression of speed and movement ${ }^{1}$. The identity of this personage is uncertain ${ }^{2}$. To the right of the funeral pyre, two eagles have begun their heavenward flight, soaring upwards as a symbol of the soul of the emperor. That there are two eagles supports the theory that the second panel illustrated the apotheosis of a Diva, for, in the texts, there is mention only of a single eagle being released from the funeral pyre.

The upper part of the ivory shows the final ascension of the Divus; he is being borne up by two naked angel-type beings, who have large wings from their shoulder-blades and smaller wings from their heads. These two figures have been described in various ways ${ }^{3}$; there is no denying, however, that they are particularly similar to the Hypnos and Thanatos which are depicted on a lekythos in the British Museum ${ }^{4}$.

Looking down from the clouds, the gods, perhaps the ancestors of the Divus, await his arrival. An arc in the right upper corner containing six signs of the zodiac, represents the sky. The central character in this composition is the emperor; all other details on the panel are there merely to clarify his position. It is especially noteworthy because it does in fact contain a number of symbols closely akin to the idea of apotheosis; the elephant as the symbol of eternity; the eagles which bear the emperor's soul to heaven; the chariot, whose driver may well be the personification of the emperor's genius, which would link the scene on earth with that in heaven.

1 A similar portrayal is found on some 'consecratio' coins, e. g. BMC Ant. Pius, no. 1425, Pl. 34.9; no. 1428, Pl. 34.3. For a recent find in sculpture, cf. L. KaHIL, Laodicée du Lycos. Le Nymphée. IIIe Partie, La Sculpture. Québec/ Paris, 1969, p. 211. Pl. LXXXIV. 2. Cat. no. 36.

2 A. St. Clarr, The Apotheosis Diptych, p. 205, identifies this figure as Sol, and makes reference to a similar representation on a coin honouring Marcus Aurelius. Cf. BMC IV p. 693. No. 25.

3 E.g. 'genii' (Kitzinger), 'wind-gods' (Volbach), 'Flügeldämonen' (Delbrück) and 'robustes gaillards' (Cabrol-Leclerq).

${ }_{4}$ The number of the lekythos is D 59. Cf. O. Dalton, Catalogue of Ivory Carvings, p. 2. Delbrück does not agree with this interpretation, but the similarity is nevertheless striking; one figure is bearded and the other beardless; both support the figure of the Divus between them. 
This ivory panel is important because it comes at the end of an epoch, and it depicts the fullness of thought behind the notion of ascension and consecration. In the context of this work, which as far as possible deals with the atmosphere and parallels around the New Testament implications of cult, it is a work of the future, a later and richer development in the thought behind the artistic portrayals of this aspect of apotheosis.

To understand the Christian concept of ascension, one must have a profound knowledge of the climate of thought at this period of history - a growing awareness of the renewal of interest in the afterlife owing to the increase of mystery-cults in the Roman Empire in the first century A.D. ${ }^{1}$. A realization that ascensions were symbolized in various ways to stress the idea of an upward movement, and a knowledge of the extent to which these symbols found their way into the various art-forms of the time, clarify the notion of glorification, and show how it was expressed to appeal to the popular imagination. Thus the whole idea of 'ascensio', which holds an important place in Christian teaching, forms part of the whole complex thought around 'life-after-death' at this epoch. During recent years, many of the traditional interpretations of the New Testament have undergone a severe scrutiny, and in particular, those concerning the glorification of Christ - His Death, Resurrection, and Ascension.

There are a number of interpretations of the Ascension, and although one may appeal to our contemporary way of thinking more than another, it is nevertheless impossible to make any final pronouncements whether the Ascension was a historical fact or not. It seems that this point is not so vital after all; the basis of Christian belief is that Christ was glorified, and this is the important, the essential part of the whole question; whether an ascension of some sort actually took place, or whether the account was merely the human expression of a reality, after the event of glorification, is of minor importance ${ }^{2}$. However, we shall look at the different interpretations

1 In particular, the relation between the ascension and the solar cults becomes more pronounced; the symbol of Helios' four-horsed chariot is taken over into Christian iconography. Cf. O. Perler, Die Mosaiken der Juliergruft im Vatikan. Freiburg/Schw. 1953, p. 20f. pp. 23ff. and Pl. XI. n. c-f.

2 Bibliography for the biblical interpretation of Ascension in New Catbolic Encyclopedia, San Francisco, Toronto, London, Sydney 1965 Vol. I, p. 933 in part. J. DaniÉlou, The Theology of Jewish Christianity, ed. and tr. by J. A. Baker. 
of Christ's Ascension, to see how they fit against a historical background.

Among the various interpretations of the Ascension of Christ, many theologians believe that it is the historical account of an extremely impressive episode before a number of witnesses ${ }^{1}$. The actual Ascension was most appropriate because it fitted in with the conceptions of the times, while at the same time, it underlines the qualities of Christ's glorified Body, which was no longer bound by the laws of gravity. R. P. Renié maintains, along with many theologians who support this school of thought, that the Ascension was a 'mouvement local', and that the Risen Body of Christ actually rose up into the air; a fact that was witnessed by his disciples and later recorded by these eye-witnesses, although the Acts of the Apostles do not give any positive hint as to those disciples who were present for this event. The cloud which hid Christ from the view of his disciples was a sign of the presence of God; a sign which was already familiar in the Old Testament, as when Moses led the Istaelites out of Egypt: "And the Lord went before them by day in a pillar of cloud to lead them along the way, and by night in a pillar of fire to give them light, that they might travel by day and by night; the pillar of cloud by day and the pillar of fire by night did not depart from before the people» ${ }^{2}$.

There is another interpretation of these texts which puts forward the possibility that Christ was "at the right Hand of the Father» on the very day of His Resurrection. Death-Resurrection-Ascension sum up the whole conception of Christ's glorification and these three stages should be considered as a single action, and not as three distinct phases in the redeeming work of the Saviour. The glorification of Christ was the conclusion of His Passion and Death, and it was not identical with the account of the spatio-temporal Ascension as given in the Acts ${ }^{3}$; it is apart from this visible Ascension, it is

Chicago 1964. E. H. Schillebeeckx, Ascension and Pentecost. Worship 35 (1961), 336-363. For the theological aspects of Ascension, cf. New Catholic Encyclopedia Vol. I. p. 936.

1 R. P. J. Renié, Actes des Apôtres. Paris, 1949, p. 42. This view reiterates that of E. Jacquier, Les Actes des Apôtres, Paris, 1926, p. 19, who maintains that 'he was lifted up'... "indique une ascension calme et historique».

2 Ex. XIII 21-22.

3 Acts I 9-11. Cf. F. X. Durrwell, The Resurrection, London/Melbourne, 1960 , p. $38 \mathrm{ff}$. 
a "change in his very being». Fr. Durrwell supports this view with the fact that St. John omits any reference to a historical event, but is nevertheless very conscious of the return of Christ to His Father, as when he records the meeting of Christ with Mary Magdalen on the day of the Resurrection: "Go to my brethren and say to them, I am ascending to my Father and to your Father, to my God and to your God» ${ }^{1}$. Should the glorification of Christ and the historical fact of ascending in the view of the disciples have been a single action, it would be inconceivable that St. John would have mentioned the one without the other ${ }^{2}$.

There are thus two different lines of thought on the subject of the Ascension of Christ, one theological and the other historical - the former stressing more profoundly the 'essential' Ascension, the glorification of Christ whereby He took His place "with the Father»; the latter is concerned with the 'actual' visible Ascension, which gave the Apostles proof that Christ was indeed glorified.

From the purely historical point of view, the fact that the essential Ascension was or was not identical with the actual Ascension is not of vital importance, though it is necessary to see the implications behind these assertions since they are at once the means of placing the Ascension of Christ on quite another plane from those of the pagan myths. That Christ ascended in the sight of His disciples is possibly a historical fact; the details given in the Acts are so precise that it would perhaps seem inconsistent to refuse credence to this section merely because it is an unlikely happening according to twentieth century standards. As part of the whole mystery of the Redemption, the Ascension of Christ for the believing Christian has many aspects which set it far above the 'types' which are found in pagan literature; there is no question of seeing this event as merely 'another in a series'. The Ascension is the culmination of the whole mystery of the Incarnation, and the prelude of the Coming of the Spirit on the newly-founded Church ${ }^{3}$.

If we accept that the purely 'essential' glorification of Christ was

$1 \mathrm{Jn}, \mathrm{XX} 17$.

2 Cf. P. Benort, Exégèse et théologie, Paris 1961, I, pp. 363-411.

3 E. Schillebeeckx, Christ, the Sacrament of Encounter with God. London, $1966^{4}$, p. 26. The author sees the Ascension of Christ as the investiture of Christ risen from the dead as universal king and Lord, the glorification of Christ, and the prelude to the giving of the Spirit and the termination of Christ's earthly mission. 
simultaneous with the Resurrection, the question arises why Christ should have seen fit to ascend from the earth in the view of his disciples 'after forty days'. If there were a historical Ascension, it was no doubt to make clear to the disciples that this was the last of His earthly apparitions; there was certainly a note of finality in the scene described in the Acts, the rising up into the sky which is further impressed on the minds of the spectators by the very definite words of the angels: "Men of Galilee, why do you stand looking into heaven? This Jesus, who was taken up from you into heaven, will come in the same way as you saw him go into heaven" ${ }^{1}$.

There is no question as to whether or not Christ would make another appearance after His visible Ascension, and the disciples realized that from this moment, they had to learn to rely on the invisible presence of Christ in His Church. But the historical setting behind the whole idea of 'ascensio' even in the form of pagan myths, reflects the mentality of men at this epoch; it is difficult to imagine the disciples having a complete understanding of the mystery of the glorification of Christ with all its implications at this point, especially before the Coming of the Spirit, but they were accustomed to the notion that the Father was in heaven, and that Christ was going to take his place at the right hand of the Father. For the non-Christians, the sign of glorification was the ascent from this world to the dwellingplace of the gods, a sign which expressed this idea clearly to the ordinary people, whom the emperors endeavoured to convince. It was essential that the disciples should understand that Christ had gone to take His place with the Father in glory, and for this reason, any occasion of doubt had to be eliminated from their minds. That Christ should use a sign which was already well-known, and which had been used in the different cultures down the centuries for the apotheosis of a ruler, was in keeping with His teaching methods throughout His public life, of underlining a truth by using a sign which already held a special significance for the people. It was by this means that they were led to understand the meaning of those spiritual truths, which of themselves would have been incomprehensible to the ordinary mind.

This is not to say that beyond all doubt, the Ascension of Christ was not a historical fact, or that it had much the same value as the pagan legends which foreshadowed it, but it is admitting that the

1 Acts I 11. 
actual event was important only insofar as it illustrated a more profound truth on a spiritual plane. By ascending into heaven, Christ used a most suggestive visual-aid, which placed in the historical background of the period, would have expressed without ambiguity the glorification of Christ.

There is a final point to be considered for those who do not accept the historical Ascension. The actual question of whether or not the Ascension took place in time and space has not been considered in these pages, and in fact, it does not affect my conclusions. In considering the Ascension of Christ as the explanation of a reality, and in admitting a historical Ascension, it is as it were Christ himself who gave the explanation directly. For those who do not accept the Ascension as historical, the same conclusions still hold, for the explanation of Christ's glorification would have been given less directly through the medium of the author of the Acts. In other words, this author realized the reality of Christ's glorification, and wishing to express it in a manner understandable to the mentality of the time, gave the description of the Ascension, which was in line with the general ideas of apotheosis of the epoch, pagan or otherwise.

\section{The Profane and Religious Implications of the Term ' E}

A term which is linked with the notion of 'saviour' and 'protector' is that of $\varepsilon \pi \varphi \varphi a v n s$, and for this reason, it may be linked with the section dealing with 'blasphemous titles'; gradually this term developed as an additional divine attribute of the Hellenistic rulers, and later on, of the Roman emperors ${ }^{1}$. As a cult-word, it is also very close to the term $\pi \alpha \rho o u \sigma i \alpha^{\prime}{ }^{2}$.

The Roman emperors always worked towards stressing the legitimacy of their position and the idea of a special link with the

1 G. Thieme, Die Inschriften von Magnesia am Mäander und das Neue Testament. Göttingen, 1906, pp. 34-36: «A conspicuous manifestation of heavenly powers

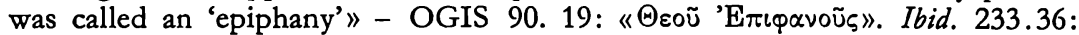

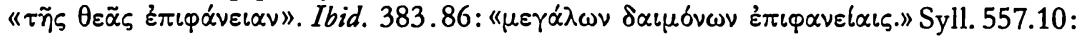

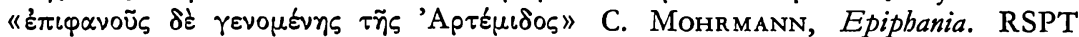
37 (1953), p. 647.

2 Cf. B. Rigaux, Les Epîtres aux Thessaloniciens. Paris, 1956. p. 204: "Sans aucun doute, dans ces textes (épîtres) 'é $\pi \iota \varphi \alpha ́ v \varepsilon l \alpha$ ' a pris la place de ' $\pi \alpha \rho o v \sigma i \alpha$ '. On pourrait parler de synonyme.» 
gods was particularly sought after. The notion of 'protecting gods' was one step in the direction, but it was only an aspect of the emperor's relationship with the gods, for he continued the well-established Hellenistic tradition of being honoured as an incarnate god; the emperor came to represent in a special way a 'deus praesens' ${ }^{1}$. As has already been noted in another context, the distinction between greatness and the divine became confused in men's minds, and the Hellenistic East had little difficulty in seeing the ruler as an ' $\theta$ sòs

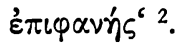

At this time, the term ' $\varepsilon$ $\pi \iota \alpha_{\alpha} \alpha \varepsilon \varepsilon$ ' developed the meaning of 'manifestation of a god', often for the purpose of bringing aid. In a certain sense, an epiphany was a 'saving' and there are definitely corresponding notions in the two expressions ${ }^{3}$. The term was very common in Asia Minor, and all over the Hellenistic East. It was usually used in connection with the solemn entry of a ruler into a city; since he was looked upon as a divine being, his coming was regarded as the apparition of a god.

Developing as it did from the Hellenistic ruler-cult into an official cult-term for imperial usage, it conveyed the glory of the visit of the emperor to a city. The emperor is looked upon as a god made manifest - there is a well-known inscription from Cos which was dated according to the number of years of Caligula's epiphany, when he made an official visit to the island ${ }^{4}$.

Although the actual entry into a city was the obvious form of an epiphany, there was also the actual identification of the ruler with a god which came to be regarded as a type of 'prolonged' epiphany, the god manifesting himself in the person of a man, whether he be Hellenistic ruler or Roman emperor.

Perhaps the best-known example from the Hellenistic period is that taken from the life of Alexander, whose ambitious exploits certainly captured the imagination of his subjects, and won for him

1 Cerfaux \& Tondriau, Culte des souverains, pp. 118-119.

2 K. Scotr, Emp. Worship in Ovid. TAPhA LXI (1930), pp. 43-69, in particular, p. 59. - O. Perler in Die Darstellung der Eucharistie auf dem Theodor-Mosaik in Aquileia. Rivista di Archeologia Cristiana. XLIII (1967), pp. 236-7 gives an example of the epiphany of Zeus-Theos from Dura Europos which influenced the representations of the imperial epiphanies.

${ }^{3}$ Cf. B. Rigaux, Epittres aux Thess., p. 202.

4 W. R. Paton \& E. L. Hicks, The Inscriptions of Cos. Oxford, 1891, p. 391:

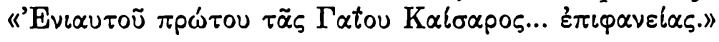


such extravagant honours towards the end of his life. The rulers used to imitate the gods, taking on themselves their attributes and acting in such a way as to stress the relationship between themselves and the gods. This would often develop to such a stage that on-lookers would tend to identify the ruler with a particular god; no longer was the ruler in the guise of Dionysus or Jupiter, but it was a manifestation of the god himself in the person of the ruler.

Plutarch shows Alexander imitating Dionysus in a procession through Carmania. Alexander was conveyed along very slowly on a raised dais drawn by eight horses, while he feasted day and night with his companions. There were countless wagons in the procession and the air was filled with the music of pipes and stringed instruments and song. Those who followed in the procession took part in all manner of bacchanalian revelry, as though, Plutarch remarks, «Bacchus himself were present ${ }^{1}$. Many of the on-lookers were no doubt convinced that the person they saw as the centre of the procession was Dionysus himself, present in the form of Alexander.

This episode would seem to be of doubtful origin, for, according to Arrian, "this statement seems incredible». Although certain authors mentioned this episode, «it was recorded neither by Ptolemy, son of Lagus, nor by Aristobulus, son of Aristobulus, nor by any other writer whose testimony on such points anyone would feel worthy of credit. It is sufficient therefore for me to record it as "unworthy of belief $»^{2}$. There is, however, a reference made to this title of Dionysus which was given to Alexander by the Athenians ${ }^{3}$.

A similar scene is described by Plutarch for Antony in 41 B.C., when he made his entry into Ephesus after his stay in Athens. Once again, we are faced with a tremendous bacchanalian procession, which must have caused a sensation at Ephesus; people dressed themselves up as Bacchus, Satyrs and Pans, and escorted Antony through the city amidst the ivy and thyrsus-wands, and the music of the harps and pipes and flutes. Antony himself was hailed as Dionysus, the Giver of Joy and Beneficient ${ }^{4}$.

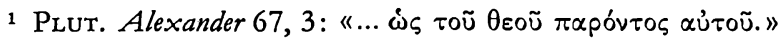

2 Arrian, Anabasis VI 28, 1 (transl. by E. J. Chinnock in The Greek Historians, Vol. II, ed. F. R. Godolphin. New York, 1942).

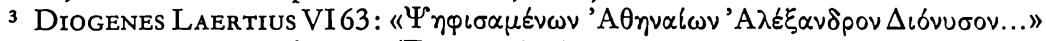

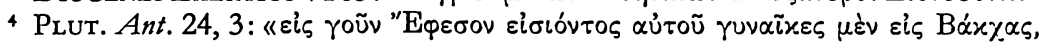


It is tempting to look on this event as a deliberate effort on the part of Antony to link himself with Julius Caesar who had a special connection with Ephesus, for it was the Ephesians who recognized

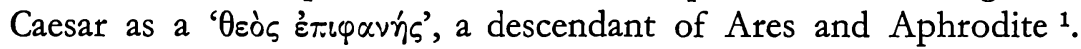
This inscription is used as a proof that Caesar was divinized during his lifetime and there is strong proof that he was identified with Jupiter before his death. This identification was, no doubt, encouraged by Caesar and his followers, and the episode of the refusal of the kingship in 44 B.C. could have been an indirect method of strengthening the ties between Caesar and his patron. Dio implies that the whole affair was suspected of having been deliberately organized; he gives the impression that this was not merely a personal suspicion, and if this was in fact the case, it is apparent how the offer of kingship could have been used to strengthen his 'divine' aspect ${ }^{2}$. When Antony had offered Caesar the diadem on behalf of the people, Caesar sent it to the statue of Jupiter on the Capitol, saying that Jupiter alone was the king of the Romans ${ }^{3}$. Had the people insisted on the kingship for him, Caesar could have accepted it, insofar as he was identified to a great extent with Jupiter. This close relationship with Caesar's patron god was again evident after his murder, when the first reaction of some of the mob was to convey the dead body to the Capitol and burn it there at the temple of Jupiter ${ }^{4}$.

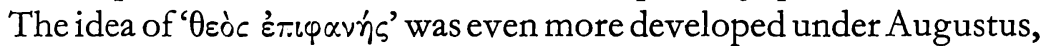
and it played an important part in the general growth of the official cult of the emperor. After a century of turmoil, the era of peace ushered in by Augustus' conquests was the inspiration of many poetic themes, and the poets of the period are full of flattery, hailing Augustus as a god manifest on earth, usually Jupiter, but also occasionally Mercury ${ }^{5}$. The testimony in poetical works is worth less

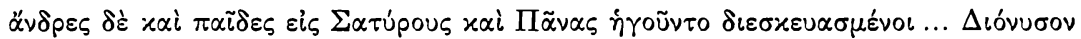

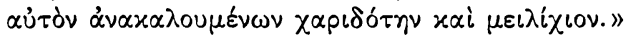

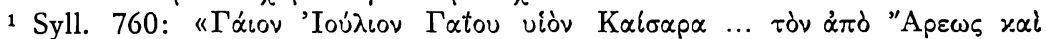

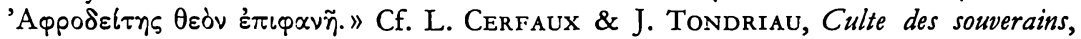
p. 298.

2 Dio XLIV 11, 2-3.

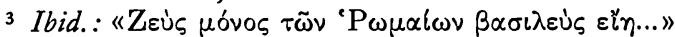

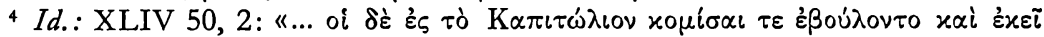

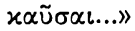

5 Cf. M. WARD, The Association of Augustus with Jupiter. SMSR IX (1933), p. 223. 
than that found in inscriptions, simply because poets were allowed to use exaggerated terms which were understood as poetic licence and thus tolerated, where other expressions of honour which tended towards the extreme were discouraged and even refused. Sometimes the flattery was more subtle. Ovid likens the palace to a home worthy of a god, and he asks if it be the home of Jupiter ${ }^{1}$.

In another context, Ovid goes even further by implying that although the relationship between the gods and the divine emperor is exceedingly close, there is nevertheless a difference between them. And, surprisingly enough, this difference is not one that lessens the prestige and dignity of the emperor, but, on the contrary, is to the emperor's advantage. It is that Augustus sometimes appears to be 'more manifest' (manifestior) and nearer to the people than the gods who are in heaven ${ }^{2}$.

Manilius mentions the close association between Jupiter and Augustus in his description of the family of the Julii, which has peopled the heavens, and which is governed by Augustus, with whom Jupiter chose to associate himself, while in the midst «stands the great and divine Romulus' ${ }^{3}$.

Although Augustus was the 'deus praesens' par excellence, he is not completely identified with Jupiter; on the contrary, it is occasionally obvious in inscriptions that though he is in close relationship with Jupiter, they are not a single entity. This point is illustrated from an inscription from an altar near Nîmes which is dedicated 'to the holiness of Jupiter and Augustus' ${ }^{4}$. In the East especially, Augustus was known as Jupiter or as Zeus Eleutherios. Two papyri from Oxyrhynchus bear witness to this in a completely unequivocal way. Both date from after the death of Augustus, during the reign of Tiberius, which means that the title continued to be used after

1 Ovid, Trist. III 1, 34-35 (ed. S. G. Owen, Oxford, 1915, repr. 1951): «Video... conspicuos postes tectaque digna deo. Et Iovis haec, dixi, domus est?»

2 Id. Pont. I 1, 63: "Ut mihi di faveant, quibus est manifestior ipse...» Cf. K. Scotr, Emp. Worship in Ovid, pp. 52-58. These pages deal particularly with the relationship of Augustus with Jupiter, especially p. 52.

3 Manilius, Astronomicon I 798-804 (ed. Th. Breiter, Leipzig, 1908): «Venerisque ab origine proles/ Julia descendit caelo, caelumque replevit; / Quod regit Augustus socio per signa tonante, / Cernit et in coetu divum Magnum atque Quirinum... Illa deum sedes; haec illis proxima, divum/ Qui virtute sua similes vestigia tangunt.»

4 H. Dessau, Inscr. Lat. Sel. II 1, 4012: "Sanctitati Iovis et Augusti.» 
Augustus' death. The first is from 19 A.D. and in it, Tiberius is called "Tiberius Caesar, Augustus Autokrator, son of the god Zeus Eleutherios Augustus» ${ }^{1}$. The second is very similar, although it comes nearly twenty years later, in 37 A.D. This is a declaration by a scribe denying any knowledge of extortion in the villages for which he is scribe. He swears an oath by 'Tiberius Caesar, New Augustus, Imperator, son of the god, Zeus Eleutherios' 2.

The term 'deus praesens' had a distinct place in the imperial cult, particularly in the Eastern part of the Empire, and the poets worked towards strengthening this belief. The effort of court poets becomes more concentrated towards the end of the century under Domitian, where one finds numerous examples in the writings of Martial and Statius.

The comparison which seemed to appeal most strongly was still that of the emperor with Jupiter; the references in the poetical works of this period are too numerous to note, and, indeed, would be unnecessary, where three or four would give the general impression of the poetical atmosphere ${ }^{3}$. It is a theme which court poets stressed considerably, possibly because it was so popular a notion; Domitian was a 'deus praesens' who insisted that he should be acknowledged as divine, and, in fact, inscriptions bear witness to this divine title outside poetry ${ }^{4}$. Domitian was also worshipped during his lifetime

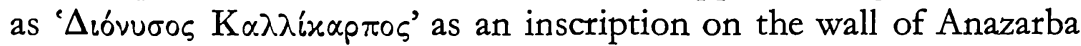
gives testimony:

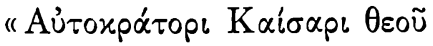

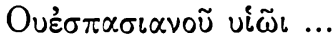

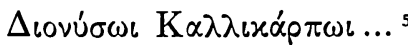

An inscription giving a decree of the town of Assos at the accession of Caligula in 37 A.D. conveys something of the eagerness of the Eastern cities to welcome their emperor as a god, and in reading it, even allowing for exaggerations common to the East, it is possible to capture something of the expectation of the people who were not

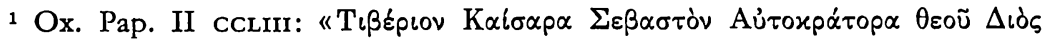

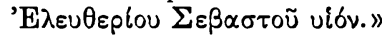

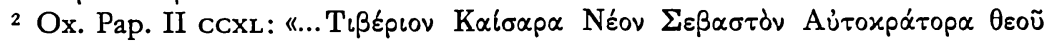
$\Delta$ iòs 'E $\lambda \varepsilon u \theta \varepsilon p$ íou $\Sigma \varepsilon \beta \alpha \sigma \tau o \tilde{u}$ víóv..."

${ }^{3}$ E. g. Martial XIV 1; IX 28, 10; IX 18, 7-8. Statius, Silv. I 6, 25-27.

4 IG XIII 1091: 'Zeus Eleutherios'.

5 Cf. J. KeIL \& A. WILhelm, Vorläufiger Bericht über eine Reise in Kilikien. Jahreshefte XVIII Beiblatt 56-8. 
atraid or embarassed to call their emperor a god ${ }^{1}$. That Caligula was recognized as a 'deus praesens' is not difficult to discern; Philo speaks of a temple in the Holy City which was to be converted into a shrine, to be dedicated to "Gaius, the New Zeus made manifest» ${ }^{2}$.

In the New 'Testament, the word 'é $\pi \iota \varphi \alpha$ 'veı $\alpha$ ' is used to describe the manifestation of Christ, his appearance in glory, for which the early Christians were constantly awaiting. C. Mohrmann sees the Christian use of the word as an image borrowed from the Hellenistic cult ${ }^{3}$. That the Christian notion of epiphany developed in comparison with the solemn entry of the Hellenistic rulers into a city is perhaps an over-simplification of the question, but there is little doubt that the use in the imperial cult must have coloured contemporary thought in the first century, and influenced the way in which the reality of the 'second coming' of Christ was expressed. This is much the same reasoning as is found in the section on the Ascension; a reality was expressed in terms which made it understandable to the general public, who were used to the idea of a solemn entry in glory of a ruler or emperor into a city, or the notion of the presence of a god in the person of an emperor. Possibly the 'Coming in glory' of Christ will be far removed from the ideas of the first century Christians of His 'Appearing', but they did indeed come to understand a future reality by a contemporary image. Whether this image was a deliberate 'borrowing' from the Hellenistic or imperial cult is doubtful, but it is likely that St. Paul was influenced by the pagan manifestations of the divine emperors, and the readers of the Epistles likewise could have hardly failed to colour the meaning of the term with what they had seen or heard of imperial epiphanies.

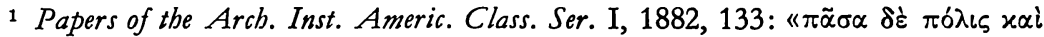

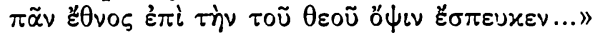

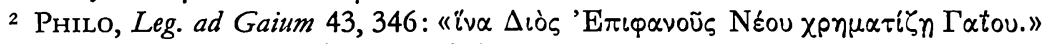

3 C. Mohrmann, Epiphania, p. 651: «Nous avons affaire ici à une image empruntée au culte du souverain hellénistique... l'avènement du Christ est comparable à l'entrée solennelle des souverains hellénistiques.» Cf. also, K. PRÜMM, Cbristentum als Neubeitserlebnis. Freiburg/Br. 1939: "Christi Kommen glich nur einem Königs- oder Kaiserbesuch in einer hellenistischen Stadt.» In contrast to this view, cf. B. Rrgaux, Epittres aux Thess. p. 234: "Les épiphanies grecques ne nous semblent que des parallèles assez lointains.» Cf. L. Cerfaux: \& J. TonDRIAU, Culte des souverains, p. 448: "Il est sûr que les chrétiens n'ont pas pris aux généraux romains l'idée que le Christ viendrait en gloire... la parousie et l'épiphanie du Christ sont essentiellement religieuses.» 
There are, no doubt, probable sources of the idea of epiphany from Old Testament writings; it is used in the Books of the Maccabees where mention is made of manifestations from heaven. In the second book, a synopsis is given which relates closely to this point; we are told the book contains the story of Judas Maccabaeus and his brothers, the purification of the great temple, the dedication of the altar, together with the war against Antiochus Epiphanes and his son Eupator, and the manifestations that came from heaven to hearten the brave champions of Judaism ${ }^{1}$.

In the following chapter, there is a vivid description of how Heliodorus attempted to confiscate funds from the temple Treasury at Jerusalem, which would have been a violation of the sanctity of the Temple. Heliodorus had already arrived at the Treasury with his bodyguard when "the Sovereign of Spirits and of every power caused so great an apparition that all who had dared to accompany Heliodorus were dumbfounded at the power of God and were reduced to abject terror ${ }^{2}$.

In the Psalms, the term is used with moderate frequency, but its translation is generally «to let one's face shine upon...». In Psalm XXXI 16 there is, in addition, the link already mentioned with 'saving': "Let your face smile upon your servant, save me in your love» ${ }^{3}$. There is a similar turn of phrase in Psalm CXVII 27, a processional hymn for the feast of Tabernacles, where the Psalmist declares: "Yahweh is God, he smiles on us...»" 4 .

Although the term is used in the Old Testament, and may very well be the root of the New Testament usage, its meaning is less like that of the New Testament, than the expression as used for the Hellenistic or imperial cult. The meaning in the New Testament has taken on some of the colour and movement of the cult-term, though I do not think its usage was to make a deliberate contrast between the imperial worship and the Christian ideas of Christ. Linked as it was with the parousia of Christ, the future Appearing of Christ took on an element of glory which was not always evident in the Old Testament use of the term. The examples quoted from the Maccabees

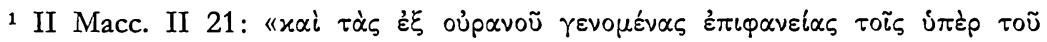

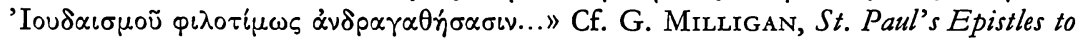
the Thessalonians, pp. 148-9.

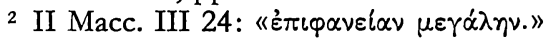

3 Ps. XXXI 16.

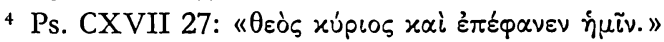


are perhaps halfway between the two interpretations; they are certainly nearer to the New Testament equivalent than the references found in the Psalms ${ }^{1}$.

In his second Epistle to the Thessalonians, St. Paul speaks of the destruction of the Rebel, when Christ will make his glorious Appearance at his future Coming ${ }^{2}$. If St. Paul were seeing the workings of the Rebel in all that was contrary to the teaching of Christ, it is possible that he had in mind those elements of the imperial cult which were excessive and blasphemous to Christian believers. In this context, St. Paul may well have contrasted the parousia of the Rebel with that of Christ. Although the two words convey the same idea as has already been noted, they are not completely synonymous in New Testament Greek; they do overlap in meaning. This is particularly clear in the previous reference, for the two words are

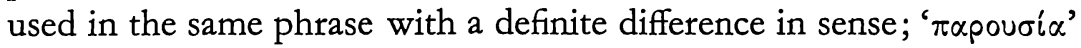
is the Coming, while ' $\varepsilon$ ' $\iota \varphi_{\alpha} \alpha \varepsilon \varepsilon \alpha^{\prime}$ ' is the actual Appearing of Christ when $\mathrm{He}$ comes.

In the Acts of the Apostles, Peter, together with the other Apostles, addressed the crowds, trying to convince them that the events of Christ's life, and the future event of His final Coming had already been prepared by prophecy: "The sun will be turned into darkness and the moon into blood before the great day of the Lord dawns» ${ }^{3}$. A similar reference is made to the Second Coming ${ }^{4}$ although neither ' $\varepsilon$ ' $\pi \varphi \varphi^{\prime} v \varepsilon\llcorner\alpha$ ' nor ' $\pi \alpha \rho \circ u \sigma i \alpha$ ' are used. At this Coming, Christ will deal with the accomplishment of salvation and not simply with sin, for the latter has already been vanquished through the first Coming of Christ. Speaking to the Corinthians ${ }^{5}$, St. Paul speaks of the gifts

1 Cf. E. Pax, 'E $\pi \iota \varphi^{\prime} v \varepsilon\llcorner\alpha$. Ein religionsgeschichtlicher Beitrag zur biblischen Theologie. München, 1955, pp. 208-214.

2 Cf. B. Rigaux, Epîtres aux Thess. Paris, 1956, pp. 196-206. L. Cerfaux, Christ in the Theology of St. Paul. New York/London, 1959, pp. 32-56. B. M. Nolan, The Parousia and the New Testament Eschatology. Irish Theological Quarterly XXXVI (1969), no. 4, pp. 288-289. For additional bibliography, p. 288, note 18.

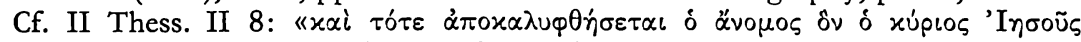

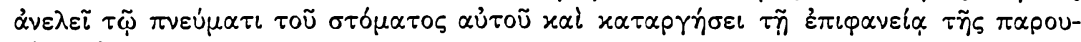

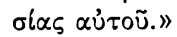

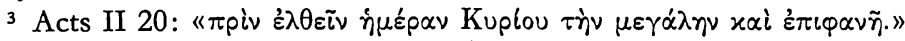

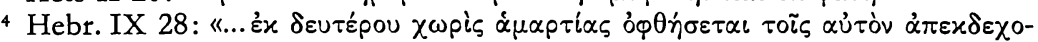

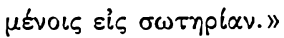

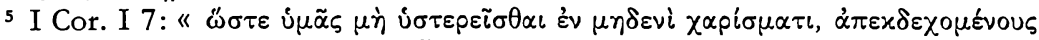

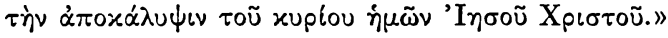


of the Spirit which are the reward of Christians who are awaiting the revelation of Christ.

This, in fact, is the life which St. Paul envisages for fervent Christians; the practice of virtue and the continuous expectancy of the future Appearing of Christ. Christ's epiphany will be a glorious event; He will appear in glory, an event which would make the imperial epiphanies but faint figures and shadows, though useful in a certain sense for a deeper understanding of a spiritual reality ${ }^{1}$.

St. Paul reiterates his views in his letters to Timothy; three times he makes references to the epiphany of Christ and the duty of all Christians to live according to the precepts taught by Christ, until the Appearing of the Lord: "I will put to you the duty of doing all you have been told, with no faults or failures, until the Appearing of Our Lord, Jesus Christ» ${ }^{2}$. In this context, there is at least a likelihood that Paul had imperial epiphanies in mind; he speaks of Christ as «the Blessed and only Ruler of all, the King of kings and the Lord of lords...» as if he were comparing Christ as a Ruler, King and Lord with the earthly rulers, kings and lords, whose activities must have been well-known to Paul, as a Roman citizen.

Epiphany in the New Testament does not refer without exception to the Appearing of Christ at his parousia, a glorious manifestation which will take place some time in the future. There is also the historical epiphany which took place at the first coming of Christ, the historical event of his Incarnation to bring about the redemption of mankind. Here again, it is possible to detect the closeness in the terms 'epiphany' and 'saviour', in much the same way as there is a link between the Incarnation and the Redemption. This interpretation is seen in the second Epistle to Timothy, where St. Paul speaks of the grace which «has already been granted to us, in Christ Jesus, before the beginning of time, but it has only been revealed by the Appearing of our Saviour, Christ Jesus» ${ }^{3}$. St. Paul uses the term 'epiphany' twice more in this short epistle, and in one text ${ }^{4}$ it is not

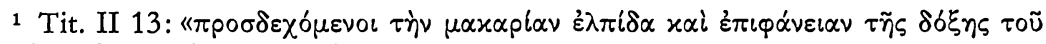

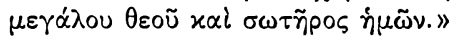

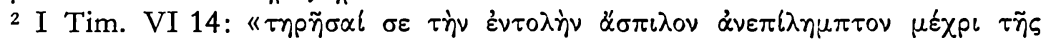

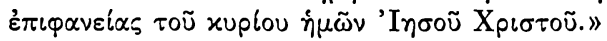

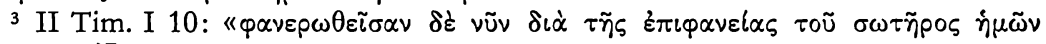

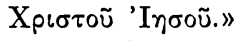

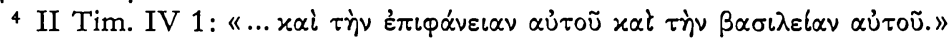


clear which Appearing he has in mind: «I will put this duty to you, in the name of His Appearing and of His Kingdom, proclaim the message and insist on it.» One's first reactions to this text is that St. Paul is referring to the first Appearing of Christ, which men had already experienced, and the Kingdom which he had founded by His Incarnation and the Redemption; not to some future kingdom of which Timothy would have had no tangible experience. This seems less likely, however, if taken in conjunction with the third reference to 'epiphany' in the epistle, which occurs only several verses later; there is no doubt about which Appearing St. Paul was thinking. He speaks of the "crown of righteousness reserved for me... which the Lord, the righteous judge will give to me on this day; and not only to me, but to all who have longed for His Appearing ${ }^{1}$. Coming as it does only a few verses after the previous mention, it is probable that the author had the future epiphany in mind in both cases.

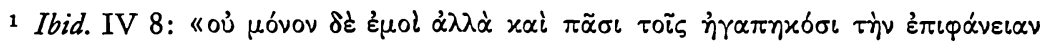
«ủं०ũ.» 


\section{PERSECUTION IN RELATION \\ TO THE IMPERIAL CULT}

The atmosphere throughout the Apocalypse is one of encouragement in the face of the powers of evil which would finally be overcome with the Second Coming of Christ. The idea of persecution permeates the pages of the Apocalypse and to neglect mention of this aspect of contact between the imperial cult and Christianity on the grounds that everything has already been said, would be to omit a substantial section of New Testament feeling on this matter, for the clash between early Christianity and the imperial authorities was brought to the public notice by the Christian refusal to worship the emperor.

The conflict is inferred explicitly in various passages of the Apocalypse and is hinted at in others. John speaks of the beast which will come out of the abyss to make war on the witnesses, and overcome and kill them ${ }^{1}$. Again, there is mention of «the beast who was allowed to make war on the saints and kill them ${ }^{2}$. But perhaps the most forceful reference to persecution is given in connection with the famous Prostitute, a type of the evil forces hostile to God. The author describes her in the most fearsome manner: "I saw that she was drunk, drunk with the blood of the saints, and the blood of the martyrs of Jesus ' ${ }^{3}$. Later on, the persecution of Christians would become more widespread, but the position in the second half of the first century is not as clear and straightforward as one might suppose. In the context of imperial worship, it is probably easier to grasp the situation after a short discussion of the position in the

1 Apoc. XI 7.

2 Ibid. XIII 7.

3 Ibid. XVII 6. 
early second century, looking at the situation when it had developed enough to form the means of judging whether or not a man belonged to the Christian sect.

\section{a) Direct Persecution and Its Causes}

There has been a tendency throughout to see and judge the imperial cult under its various aspects from a Christian point of view, endeavouring to judge the significance of State-controlled worship in an atmosphere of developing Christian thought and attitude. To obtain a glimpse of the Roman view of Christianity, one of the best means is found in studying the correspondence of Pliny the Younger with the emperor Trajan, while the former was attempting to restore order in the disorganized province of Bithynia and Pontus. Having received a number of accusations «sine auctore» containing a great number of names of Christians, Pliny was anxious to know the right way of settling the issue. It seems that the mere acknowledgment of being a Christian was in itself a crime, or that the Christians performed certain criminal deeds. Some of the suspects at once sought to clear themselves by offering wine and incense to the statue of the emperor, recognizing him as the guardian spirit of the empire ${ }^{1}$.

Eusebius, however, looks on the correspondence of Pliny from quite a different point of view. As governor of Bithynia, Pliny was alarmed at the number of martyrs, the result of intensive persecution, and so he sent a report to Trajan of the numbers who were being put to death for the Christian faith. Trajan's reply that Christians were not to be hunted out, but punished only if they were met with, meant, according to Eusebius, that the threat of persecution was stifled at least to some extent ${ }^{2}$.

1 Pliny, Letters X 96. Cf. L. Номо, Les empereurs romains et le christianisme. Paris, 1931, p. 52 f. P. DE LABRiolle, La réaction paienne. Paris, 1934, pp. 28-35, makes some remarks concerning the authenticity of these Letters. J. LAST, The Study of the Persecutions. JRS XXVII (1937), p. 91 notes that the reason for this policy is not given - the correspondence between Pliny and Trajan does not give any clue. He adds: "One thing, however, is certain: the correspondence does not prove that the Christians were oppressed because they refused to supplicate pagan gods.»

2 Eusebius, $H E$ III 33, transl. G. A. Williamson. New York, 1966. 
Pliny put forward a series of questions which gave the impression that his situation was not so common at this epoch, that precedents had not been formed nor stereotyped answers prepared to meet all such occurrences. Seemingly similar experiences by governors of neighbouring provinces were not there to guide Pliny in the making of decisions in these matters, and he was obliged to place his diffculties before the emperor himself. Pliny realized that Christianity was a crime, but was unable to decide whether the criminal offence was in the fact that Christianity was something worthy of condemnation.

Pliny wished to know whether certain distinctions would be legitimate in assessing such crimes - should the age of the 'criminal' be taken into account? Should the obviously repentant be entirely forgiven? Those who readily confessed that they held the Christian beliefs were forthwith punished; as much to correct the grave fault of obstinacy as to punish Christians for their religious tenets. Believers who were Roman citizens escaped on-the-spot condemnation, but were sent off to Rome to be tried, since all Roman citizens had the right to appeal to Rome, as St. Paul appealed to Caesar ${ }^{1}$. "Caesarem appello» was a solemn formula, which gave the accused men the right to go to Rome from whathever part of the empire they were at the time, in order to be judged by the emperor in person. This appeal could either be made in writing or else by word of mouth.

Charges were also made anonymously, but these were not encouraged, as they were looked on as a very pernicious means of maintaining justice and order. In his reply, Trajan gives directives that such accusations should be ignored unless signatures be attached, as such practices could become dangerous tools in the hands of a weak ruler. Some of the accused immediately denied that they had ever belonged to the Christian sect, and as a proof of their unfailing loyalty to the emperor, repeated invocations after the governor, and religious rites of wine and incense were offered by them before Trajan's statue. This had been placed on purpose with those of the gods, and they finally went so far as to blaspheme the name of Jesus, which proved conclusively they had no longer adhered to the Christian faith. Any suspected Christian cleared his name once he had worshipped the

1 Acts XXV 11. 
statue of the emperor and the images of the gods, while, at the same time, they blasphemed the name of Christ.

In connection with these pledges of loyalty to the emperor, a description is given of the innocuous 'agapé' celebration, around which grew up such a veil of mystery and suspicion. Charges were brought against the Christians for many atrocious crimes, including the sacrifice of children, but in this letter, it is affirmed that, according to Pliny's informant, the Christian meeting involved nothing more than an innocent meal taken in common, during which the participants bound themselves by oath to avoid fraud, theft or adultery. In spite of Pliny's attempt to discover any deeper significance by torturing two slaves - deaconesses, - nothing further came to light which was, up to this point, not known.

Pliny's attitude towards Christianity was that it was a contagious superstition, which, although widespread to the point of leaving the pagan temples deserted, could be overcome if the necessary steps were taken. The offering of a pardon to those who 'repented' would, no doubt, have reaped good results among those who were unable to face the consequences of their action if they refused to honour the emperor by not offering incense to his statue, the 'statue of the beast'.

Early evidence for persecution during the first century is sketchy and far from satisfactory; much is surmized by later writers, until it is difficult to make unbiased judgments as to the extent and importance of Christian persecution. Melito's Apology from the middle of the second century A.D. ${ }^{1}$, speaks of Nero and Domitian "who alone have wished to accuse our doctrine, from whom also it has come to pass because of this absurd custom of false accusation that falsehood has become current against the Christians». From its origin, the Christian Church was the object of persecution both from its Jewish and its imperial adversaries. The Jewish conflict was brought about almost naturally from the fact that Christianity was born from Judaism; it accepted the Bible and much of its cultural development and history, and yet it rejected Judaism as a religion of the new covenant and it is for this reason that antagonism developed.

The imperial persecution began later in the century, and for

1 Eusebius, HE IV 26, 9. Also, L. H. Canfield, The Early Persecutions of the Christians. New York, 1913, p. 150. 
different motives. Christianity, like Islam, is a convert-making religion; it could thus prove a danger to society and undermine the authority of the State, since much of its teaching was in conflict with official state teaching and religion, and the Kingdom of Christ was suspected to be taking the place of the empire of the Caesars.

It would seem that Christianity only became a 'crime' towards the end of the first century under Domitian or in the early years of the second century; before this, persecutions had been local affairs, due to diverse causes and of short duration. Tacitus makes it quite clear that even though he has little patience with Christianity and looks upon it as a 'dangerous superstition', the charge that the Christians were responsible for the fire which started in Rome in 64 A.D. was quite false and was put forward in an attempt to counteract reports which were (circulating), putting the blame of the fire at Nero's own door ${ }^{1}$.

The first persecution was local rather than universal, and the number of martyrs is unknown, although Tacitus speaks of 'a vast multitude'. There is, however, no evidence from the passage of Tacitus that the persecution had anything to do with a Christian refusal to join in the imperial cult worship ${ }^{2}$, though it would appear from this context that it was the direct result of Nero's attempt to escape blame for the great fire of Rome by accusing the Christians, who were generally detested by their pagan contemporaries. In order to put a stop to the rumour which was so obviously putting forward Nero's name as the instigator of the fire, Nero inflicted torture and other punishments on those Christians, who, according to Tacitus, were hated because of their abominations and crimes ${ }^{3}$.

At this point, Tacitus gives a short account of the reason for the name of Christians, and briefly establishes the historical background for the death of Christ. This author then notes that the first to be

1 Tac. Ann. XV 44, 2: «Ergo abolendo rumori Nero subdidit reos, et quaesitissimis poenis adfecit, quos per flagitia invisos vulgus Christianos appellabat.»

${ }^{2}$ Cf. H. Last, The Study of the Persecutions. JRS XXVII (1937) pp. 89-90: "There is nothing in fact to suggest that the Neronian attack was undertaken because the Christians were held false to some religious duties imposed on them either by their Roman citizenship or by their inclusion in the Roman Empire.» Also, R. M. Grant, Pliny and the Christians. HThR XLI (1948) no. 4, pp. 273-4, for a comparison with the position at a later date.

3 TAC. Ann. XV 44, 4, cf. above note 1. Also cf. p. 151, note 3, the letter of Clement of Rome to the Corinthians. 
arrested were those who openly confessed their faith ${ }^{1}$, and then later when confessions had been wrung out of those known to be Christians, a great number were taken ${ }^{2}$.

Tacitus was no longer attempting to keep to the original charge; with such great numbers under arrest, it was no longer convincing that so many had been involved in the original crime of setting fire to Rome. As a trumped-up charge was necessary to 'legalize' the arrest of these Christians, they were accused of 'odium humani generis' - hatred of their fellow-men. As far as it was possible to read into these words, there is no indication that this charge included a hatred of the emperor insofar as he tried to usurp the place of God in the lives and worship of the Christians, and indeed of all men. However, Nero's hatred of Christians which resulted in his choosing them to act as his victims, was no doubt fanned into flame by the Christians' refusal to give Caesar divine honours, and already the emperor must have been well aware of the situation and would want to revenge himself on the Christians in this way.

Tacitus then gives some details of the torments inflicted on the Christians; not only were they killed, but they were forced to meet death in the most inhuman fashion; covered with animal skins, they were torn apart by dogs ${ }^{3}$. Another example of Nero's extreme lust for cruelty is seen in the order to use Christians as 'living torches' to light up the imperial gardens; attached to crosses, they were set alight, a sadistic parallel to the crime which they said to have committed ${ }^{4}$.

Ch. Hülsen put forward a plausible solution to this question of motive on the part of the emperor, by suggesting that the Christians may have aroused suspicion, if, after the fire, they abstained from taking part in the sacrifices and processions offered to the gods in an attempt to regain their favour. This could have given the impression that they were in some way connected with the fire ${ }^{5}$.

1 Ibid. XV 44, 4: "Igitur primum correpti qui fatebantur...»

2 Ibid.: "Deinde indicio eorum multitudo ingens... convicti sunt.»

3 Ibid.: «Et pereuntibus addita ludibria, ut ferarum tergis contecti laniatu canum interirent.»

${ }^{4}$ Ibid.: «... aut crucibus adfixi [aut flammandi, atque] ubi defecisset dies in usum nocturni luminis urerentur.»

${ }^{5}$ CH. Hülsen, The Burning of Rome under Nero. AJA 13 (1909) pp. 45-48. This was denied by A. BouchÉ-Leclerce, L'intolérance religieuse et la politique. Paris, 1911, pp. 106-157. This author affirms that the supplication to Vulcan, Ceres and Proserpina was not a great feast; Roman citizens alone were invited 
Tacitus gives the traditional view of the persecution under Nero, but there is much to suggest that he could have misinterpreted the facts and linked together two unconnected happenings, the fire of Rome and the persecution of the Christians. For Tacitus is not the only source of the Neronian persecution, and the other sources do not connect the fire with the ensuing persecution ${ }^{1}$. Suetonius, for example, lists a number of things which were punishable and repressed under Nero - eating-houses were forbidden to have anything other than vegetables and the like; the games of the charioteers were forbidden and the factions of the pantomine players were banished, together with the players themselves ${ }^{2}$. Under the same repressive measures, the Christians, whom Suetonius considered as the members of a new and pernicious superstition, were severely punished. There is no mention that this punishment was for any specific crime, yet had this been the case, there would be little doubt but that it would have been mentioned.

Clement of Rome, writing to the Corinthians, in the last year of the first century A.D., refers to the «jealousy and envy» that caused the persecution and martyrdom of «the greatest and most holy pillars» ${ }^{3}$. Peter was martyred through "unmerited jealousy» and Paul's terms of imprisonment were the result of «jealousy and strife» 4 as was the torture and martyrdom of vast numbers of Christians.

Clement is, no doubt, referring to the Neronian persecution and the "jealousy and strife» is probably an allusion to the jealousy of

to take part in such festivities, and Jews and Christians would not have been expected to attend. He adds: "Dans une si grande ville, de population si mêlée, même l'abstention de citoyens romains eût passé inaperçue.» This is true, but the very fact that Christians and Jews did not take part in such sacrifices would leave them open to suspicion and calumny during times of calamity, especially by those who were looking for a scape-goat.

1 For a discussion of the motives alleged by Tacitus and Suetonius, cf. A. BouCHÉ-LECLERCQ, L'intolérance religieuse, p. 106 ff.

2 Suet. Nero 16, 3: "Multa sub eo et animadversa severe et coercita nec minus instituta; adhibitus sumptibus modus; publicae cenae ad sportulas redactae; interdictum ne quid in popinis cocti praeter legumina aut holera veniret, cum antea nullum non obsonii genus proponeretur; afflicti suppliciis Christiani, genus hominum superstitionis novae ac maleficae; vetiti quadrigariorum lusus, quibus inveterata licentia passim vagantibus fallere ac furari per iocum ius erat; panto minorum factiones cum ipsis simul relegatae...» Cf. J. Moreau, La persécution du christianisme dans l'empire romain. Paris, 1956, p. 18.

${ }^{3}$ Clement, To the Corintbians 5, 2, ed. by James A. Kleist, The Epistles of St. Clement of Rome and St. Ignatius of Antioch, London, 1946, p. 87.

4 Ibid. p. 12. 
Jews provoked by the success of the Christians and the numbers of their converts ${ }^{1}$.

It is generally accepted that the persecution mentioned throughout the Apocalypse applied to the later struggle against the Christians under Domitian. Towards the end of the reign of Domitian, there was a furious attempt to crush Christianity from the empire before it was too late, and there is evidence that seems to establish that some of the victims at least, held high positions in the state. In 91 A.D., the ex-consul Acilius Glabrio was obliged to fight a lion and two bears, and Dio records the death of Flavius Clemens in the year 95 A.D., saying that he was slain 'along with many others' 2 The charge against them was 'atheism', which might well have been the charge brought against the Christians; it was also described as 'living according to Jewish ways'. Part of the same movement was the banishment of the wife of Flavius Clemens, Flavia Domitilla, to the island of Pontia, and John, the author of the Apocalypse, to the island of Patmos. Eusebius describes Flavia Domitilla as the niece and not the wife of Flavius Clemens ${ }^{3}$, a consul at Rome for that year, who was sent into exile to the island of Pontia because she bore witness to Christ.

According to the Apocalypse, the persecution extended to Asia Minor and it would appear that this time it had very definite connections with the imperial cult; all were persecuted who refused to wear the mark of the beast on their foreheads ${ }^{4}$.

The position of confessing Christians under Trajan was that they were worthy of death, and this was the aftermath of the period of persecution under Domitian. Tertullian gives two reasons why Christians might have been looked on as 'public enemies'; firstly because they did not offer vain and flattering honours to the emperor, and secondly, because they did not take part in the celebrations of the imperial feastdays, except in the interior of their hearts ${ }^{5}$. The festivities would include processions and prayers for the emperor

1 Ibid. p. 105 note 25.

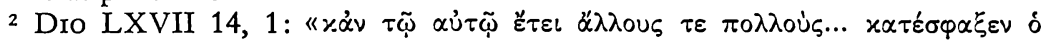

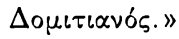

3 Eusebius, HE 3, 18.

4 Cf. L. H. Canfield, Early Persecutions, pp. 83-4.

5 Tert. Apol. 35, 1: «Propterea igitur publici hostes Christiani, quia imperatoribus neque vanos neque mentientes neque temerarios honores dicant, quia verae religionis homines etiam solemnia eorum conscientia potius quam lascivia celebrant.» 


\section{PARADOSIS}

Contributions to the History of Early Christian Literature and Theology XXIII

Sr. DOMINIQUE CUSS, F.C.J.

IMPERIAL GULT AND HONORARY TERMS IN THE NEW TESTAMENT 
and because the Christians failed to take part, any calamity would be laid at their door, and they would be held responsible. Another aspect of the importance of such participation is seen in the lines of Ovid ${ }^{1}$, where the poet lists the acts of devotion which true citizens should pay to their emperor. The offering of incense and the paying of vows to the emperor were tokens of loyalty towards the State ${ }^{2}$. Therefore it is easy to see how abstention from such acts, even on religious grounds, came to be interpreted as disloyalty to the State. Religious differences at once took on a political aspect ${ }^{3}$. It was unfortunate for the Christians that the expression of loyalty to the imperial authorities should have been the direct worship of the emperor, for in this they were unable to comply, although they might be good citizens on every other count. It was the deification of the emperor, the divine honours which were offered to him, even during his lifetime, which savoured of Anti-Christ, and it was against this that the Christians had to struggle. The attitude of the author of the Apocalypse is quite different from that of St. Paul in his letter to the Romans ${ }^{4}$, and it would seem that the whole situation had changed radically since 57/58 A.D. Even under the second period of persecution, it was not the State as an institution that was questioned and refused, but the means of ascertaining loyalty to the State ${ }^{5}$.

Although the general impression from Christian sources was that the persecution towards the end of the century under Domitian was considerably more widespread than that of the Neronian epoch, not all later writers support this view; Tertullian certainly gives a milder description than the author of the Apocalypse. In comparing the two periods of strife, Tertullian speaks of Nero as the first to wage war on the Christians with 'the imperial sword'. He goes on to describe Domitian, who had much of the cruelty of Nero, and how this emperor inaugurated a period of persecution which was of seemingly short duration, "for, being in some degree human, he

1 Ovid, Trist. II 53-60.

2 Cf. K. Scotr, Emperor Worship in Ovid. TAPhA LXI (1930) p. 58.

3 Cf. S. L. Guterman, Religious Tolerance and Persecution in Ancient Rome. London, 1951, p. 160. This author gives the modern equivalent to such a situation in the present-day salute to the flag of the country, which is more a political than a religious ceremony.

4 Rom. XIII 1-7.

5 Cf. W. R. Halliday, The Pagan Background of Early Cbristianity, Liverpool, 1925 , p. 24. 
soon stopped what he had done and restored those he had banished» ${ }^{1}$.

It is difficult to judge from historical sources only, the extent and duration of this second persecution, but it probably started towards the end of Domitian's reign, and was brought to a conclusion only by his death. With Domitian's developing awareness of the possibilities of his own divine status, it is evident that the framework of loyalty-testing by imperial worship was gradually constructed during his reign ${ }^{2}$.

\section{b) Indirect Persecution}

Writing about persecution, brief mention should be made of the other groups which suffered restrictions in some form, so as to avoid the impression that it was the Christians only who suffered in this way. Apart from direct persecution, a more subtle means of control was exercised by the State affecting all groups which could be a potential danger to the State or emperor. Owing to the uncontrollable number of slaves, the emperor realized the danger of organized groups trained to work together for any purpose. Secret societies had always been regarded with suspicion but Augustus went even further in keeping a close scrutiny on any religious society and, if unregistered, it could be suppressed and its members punished. Various examples under Augustus illustrate this point; one of the most striking is his refusal to allow a private fire-brigade to function even for the common good, since its members could easily become a danger to the State whose standing army was inadequate to meet such disasters as might result from such bodies of men. This caution on the part of the emperors continued well after the time of Augustus. In reply to a request by Pliny to institute a guild of firemen consisting of a hundred and fifty members, Trajan drew his attention to the fact that the province in general, and Nicaea and Nicomedia in particular, had been greatly disturbed by such societies ${ }^{3}$; Trajan's view

1 Tert. Apol. 5, 3-4: "Consulite commentarios vestros, illic reperietis primum Neronem in hanc sectam cum maxime Romae orientem Caesariano gladio ferocisse. Sed tali dedicatore damnationis nostrae etiam gloriamur... Temptaverat et Domitianus, portio Neronis de crudelitate, sed qua et homo, facile coeptum repressit, restitutis etiam quos relegaverat.»

2 Cf. E. G. Selwyn, The Persecutions in I Peter. SNTS Bulletin I (1950) p. 47.

3 Pliny, Letters X 34: "Sed meminerimus provinciam istam et praecipue eas 
was that whatever the aim of forming a guild, it would end up as a political association before long, and thus prove a menace to those who had to keep the peace.

Unregistered clubs were looked upon with grave suspicion and trade unions were likewise considered potential hives of unrest and had no legal status until the reign of Septimius Severus. But gradually the steadily increasing concept of unity gave rise to the formation of sodalities and clubs at a local level, which included artisans and traders of all sorts.

The position of religious societies and clubs attached to the various cults and religions of the Empire was safe insofar as they were generally accepted. As Workman has pointed out, the Romans were great opportunists, and protected and encouraged the cults which were prevalent in a given area; in Jerusalem, the interests of Jehovah were protected, in Ephesus, those of Artemis ${ }^{1}$. In an empire which boasted of many different tribes and races, toleration could only be a local affair anyway, as different gods had the monopoly of worship according to the region. There are instances of various religious groups being restricted, as, for example, the Bacchanalia in the second century B. C. By the Senatus Consultum de Bacchanalibus in 186 B. C., the Bacchanalia were forbidden and all secret rites whether public or private ${ }^{2}$. Livy states that the task was entrusted to the consuls of destroying forms of Bacchic worship, first of all at Rome and then throughout Italy ${ }^{3}$.

In the early Empire, the cult of Isis was restricted by Augustus when he forbade Egyptian rites to be celebrated inside the pomerium in 28 B.C. ${ }^{4}$. A scandal at the temple of Isis at Rome was the cause

civitates eius modi factionibus esse vexatas. Quodcumque nomen ex quacumque causa dederimus iis, qui in idem contracti fuerint, hetaeriae aeque brevi fient.»

1 Cf. H. B. Workman, Persecution in the Early Church, p. 38. H. Idris Bell, Cults and Creeds in Graeco-Roman Egypt. Liverpool, 1954, p. 82: "It is a fallacy to suppose that the Romans persecuted any form of religion purely on grounds of religious belief... When she attempted to suppress a cult, she did so on moral or on political grounds, or on both together."

${ }^{2}$ CIL I$^{2} 581$ Dessau, Inscr. Lat. Sel. I 18. Livy XXXIX 18, 7: «Datum deinde consulibus negotium est ut omnia Bacchanalia Romae primum, deinde per totam Italiam diruerent. $)$

${ }^{3} I d$. XXXIX 18, 8: "In reliquum deinde senatus consulto cautum est ne qua Bacchanalia Romae neve in Italia essent.» Cf. Lex. Alt. Welt, col. 426427. Also, M. P. Nilsson, The Dionysiac Mysteries of the Hellenistic and Roman Age. Lund, 1957, p. 18.

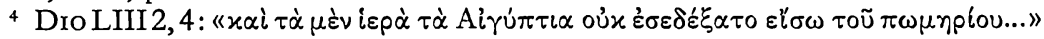


of the persecution ordered by Tiberius, when the priests of Isis were crucified, the temple of Isis was razed to the grounds and the statue of Isis was thrown into the Tiber ${ }^{1}$. Suetonius relates how Tiberius forbade foreign religions and forced the followers of Isis to burn all their vestments and sacred vessels ${ }^{2}$.

The Jews likewise suffered in the same year under Tiberius, apparently because of the great number of converts which they were making ${ }^{3}$. The Jewish youths were sent from Rome to Sardinia on the pretext of performing their military service, while the others were exiled from Rome ${ }^{4}$. This policy was renewed under Claudius, when the Jews were exiled from Rome, because they were said to be a source of disquiet by their continual uprisings ${ }^{5}$.

There is some doubt as to the fate of the astrologers and the magicians; according to Suetonius, Tiberius wanted to banish them but was won over by their supplications and allowed them to remain on the understanding that they gave up the practice of their arts ${ }^{6}$. Dio is more explicit in his account of the fate of the astrologers and magicians; in 16 A. D., Tiberius put to death those who were foreigners and banished all those who had not given up the practice after his previous decree forbidding their arts ${ }^{7}$.

Christianity, with its strict views on monotheism and its worldwide claims, soon found itself regarded with acute suspicion which developed steadily until it finally erupted into persecution. It is

For Augustus' attitude towards foreign cults, cf. SuEt. Aug. 93, 1: «Peregrinarum caeremoniarum sicut veteres ac praeceptas reverentissime coluit, ita ceteras contemptui habuit.» For bibliography for Isis-cult, cf. G. Wissowa, Religion und Kultus der Römer. Munich, 1902, pp. 292-299. FR. Cumont, Les religions orientales dans le paganisme romain. Paris, 1929, pp. 69-94. P. F. Tschudin, Isis in Rom. Basel, 1962. R. Mer KelbaCH, Die griechischen und römischen Isisfeste. 1964, Lex. Alt. Welt, col. 1412 .

1 Jos. Ant. XVIII 65-80.

2 Suet. Tib. 36, 1: «Externas caerimonias, Aegyptios... ritus compescuit, coactis qui superstitione ea tenebantur religiosas vestes cum instrumento omni comburere.»

3 Dio LVII 18, 5.

4 SUET. Tib. 36, 2: «Iudaeorum iuventutem per speciem sacramenti in provincias gravioris caeli distribuit, reliquos gentis eiusdem uel similia sectantes urbe summovit sub poena perpetuae servitutis nisi obtemperassent.»

5 Suet. Claud. 25, 11.

6 Suet. Tib. 36, 3: «Expulit et mathematicos, sed deprecantibus ac se artem destituros promittentibus ueniam dedit. »

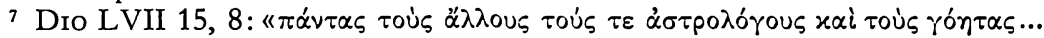

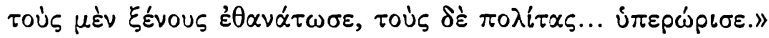


interesting to note, that in spite of the many details in which Christianity might be likened to Mithraism, at least exteriorly, nevertheless Mithraism was not a persecuted religion, and even won the privilege of having emperors among its devotees, long before Christianity was an accepted religion. This was due to the fact that Mithraism sheltered itself behind the religion of the Great Mother, whereas the Jewish religion quickly found itself in a position where it was more expedient to cause a rift between itself and the developing Christianity. While Mithraism was able to gain strength from the fact that it absorbed into itself the best elements found in the surrounding paganism, Christianity had always remained aloof from any contamination through contact with non-Christian sects, and it contained an absoluteness which would not accept the idols of paganism, whether they be found in the statue of a god, or the image of an emperor. It is perhaps this sense of the Absolute which has held Christianity together down the ages. The sense of the Absolute did give a very real sense of security which formed the climate for early Christian thought and living.

This background of liberty for the extension of local cults shows clearly the necessity for Augustus to establish a religion common throughout the empire with which to link together the creeds and races scattered throughout the whole empire. This cult of the emperor had similar festivals, temples, priesthood and sacrifices to those which grew up in the Christian Church and it was because of the similarities that much of the antagonism grew up in the following centuries until the conversion of Constantine.

Imperial worship was at its most fervent in Asia; after the decline of Pergamum, Smyrna became the great centre of Asiatic worship, and though in the West this new religion was often merely a patriotic formality, in the East there was a great tendency to pay to the emperor the honours which were given to the local deity. Not only the emperor, but also his family, were eligible for divine honours.

Christians were adamant in their refusal to accept the idea of imperial apotheosis, despite the various devices brought forward to disguise the worship paid to the emperor, and the attribution of divine prerogatives to men. It was this refusal of the Christians that caused them to be looked upon as anarchists and enemies of the State, and they were easily discernible when it came to offering sacrifices of incense to 'Caesar the Lord' as opposed to 'Christ the 
Lord'. Thus on the great imperial feast-days, the mob-violence towards Christians was looked on as an expression of loyalty towards the emperor, and, for this reason, the magistrates were loth to prevent such activities, even if only on political grounds. An example of this is the martyrdom of St. Polycarp, who suffered death at Smyrna on February 23rd 155 A.D. on a festival-day of Smyrna ${ }^{1}$.

Pagan superstition was, no doubt, an important factor in the persecution of Christians; any natural catastrophe was interpreted as the failure of Christians to placate the gods with sacrifices. This opinion reached a climax in the fourth century when the barbarian invasions were blamed on the continual neglect of the gods by the Christians. The Christians themselves did much to form popular opinion against them, because of their seemingly magical practices and their extreme ideas on chastity, which, in Roman eyes, undermined the institution of marriage, as it was forbidden for a Christian to marry a heathen.

The ill-will of the Jews was another potent cause of unrest; hostility between Christian and Jew continued to grow, owing in part to the fact that the Christians were often considered as one section of the Jewish religion. The Jewish Christian, in particular, was in a difficult position as he was regarded as neither Christian nor Jew ${ }^{2}$.

The imperial authorities persecuted Christianity because it could so easily prove the cause of political disturbance; their condemnation was the consequence of their strong loyalties to a Saviour and Lord who was not a Roman emperor. This, coupled with a Christian refusal to worship the emperor, was considered as disloyalty, and from a Christian point of view, there was no compromise between Christ and Caesar.

1 For a discussion of the date of the martyrdom of St. Polycarp cf. P. TH. Camelot, Martyre de Polycarpe. Sources chrétiennes. Paris, 19694, p. 199.

2 H. B. Workman, Persecution, p. 52. The two permanent causes for persecution of the Christians outside all political or social spheres are discussed by this author. 


\section{CONCLUSION}

The imperial cult in its early stages did not constitute a threat to one particular religion except in isolated instances, such as Caligula's intention of erecting his statue in the Temple of Jerusalem which could have developed into a serious threat for the Jewish religion. From inscriptions and papyri, it is evident that the imperial cult was widespread even by the end of the reign of Augustus, yet it was only towards the end of the first century that imperial worship was demanded by the emperor, and it was at this point that the apparently insoluble difficulties arose. It is significant that in the Gospels there is no apparent clash between the imperial authorities and the first Christians; Christ himself preached a doctrine which accepted the pagan domination in its political sphere, although it must be kept in mind that the Gospels were not intended as a political handbook. Similarly, St. Paul was far from condemning the Roman Empire; he advocated loyalty and prayers for those in authority, and there is nothing in his writings which leads us to suppose that this Empire was obliging Christians to act in a way that was totally contrary to their beliefs and loyalty in the religious sphere.

The Christian religion had always been suspect insofar as it was totally different from existing religions, but it could hardly be described as a religion for slaves and fanatics; in the first years of the Christian community, many middle-class people were named as Christians ${ }^{1}$. Possibly as persecution took its toll, the numbers of

1 In Acts XVII $11 \mathrm{f}$. Paul and Silas preach in Beroea where they find the Jews are more open-minded and ready to listen than those of Thessalonika. Many Jews were converted during this visit, as well as «many Greek women from the upper classes. Ananias and Sapphira were landowners (V 1) and Tabitha (IX 36) spent her time "doing good and giving in charity", which presupposes that she was not destitute herself. Cf. C. SpICQ, Les Epitres Pastorales. I. Paris, 19694, Excursus I. Les Femmes chrétiennes, pp. 423-424. 
this class of people diminished; it became increasingly difficult to remain a Christian in a prominent position whereas the slaves and lower classes in general were protected by the anonymity of their lack of rank.

The whole climate surrounding the Apocalypse of John is totally different; there is a completely changed atmosphere and the position of the Christians had undergone a radical change. Now the imperial authorities have taken a deliberate stand and imperial worship made obligatory. Gradually the custom grew up of persecution for non-conformity in this policy. In the Apocalypse, the Christians were encouraged to bear with the persecution and they were given a strong element of hope in the truth that Christ would return and conquer the enemies of his followers.

Persecution was, on the whole, a local affair during the first century and the willingness of the Christians to endure a cruel martyrdom gave a certain glamour to the atrocities perpetrated in an attempt to stamp out any possible disloyalty to the State. This attitude was in itself an embarrassment to the Roman authorities, who were loth to encourage what seemed to them to be an unnecessarily fanatical point of view, and it was unfortunate for both sides that the test of loyalty should have been this question of imperial worship, for this was the one point where there could never be any compromise between the two.

Because of the vastness of the subject, I have limited this work to some of the less-known aspects of the cult, which, although on the periphery of imperial worship, nevertheless played their part in building up the atmosphere around the person of the emperor. Necessarily, there are some points which have already received considerable attention such as the whole question of persecution, but to omit them would have given an incomplete overall view. The material aspects of the imperial cult have already been treated in detail - altars, statues, processions and games, to name the most obvious. This work deals more with the notions behind cultterms and expressions, and the possible scandal which could have been given by Christian and pagan alike. On the whole, I have not attempted to give the source of Christian terms, which are externally similar to those used for honorary purposes or directly for cultworship, but rather I have tried to see how far pagan usage could have influenced the meaning of the terms in the Christian sense. 
The greatest difficulty for the historian is that his judgment may be influenced by subsequent knowledge, and in the case of the imperial cult there is a danger of applying the later developments to an earlier period, which would necessarily complicate the whole question. For this reason special stress has been laid on the evidence of inscriptions and from contemporary texts.

Since this work has been confined to terms and aspects of cult-worship implied in the New Testament, it was not intended to give a complete survey of the development of the cult during the first century. The majority of such New Testament references are found in the Apocalypse, and for this reason, the position of the imperial cult as it was towards the end of the first century has tended to dominate the scene. In some case, it has been necessary to go beyond the limits of the first century to find a suitable illustration for a point, as, for example, in the case of the notion of ascension; the first century is singularly poor in pictorial evidence compared with the following centuries, when the idea developed considerably from the reign of Antoninus Pius onwards. Apart from the textual illustrations from the Hellenistic epoch, examples have in general been taken from the first century A.D., and the correspondence of Pliny and Trajan is among the latest. Exceptions from later centuries, such as excerpts from the writings of Tertullian, or from the Synod of Elvira, have been used to stress particular points by giving a glimpse of their future development. 


\section{SCRIPTURAL INDEX}

Old Testament

Exodus IV 22, p. 74. XIII 21-22, p. 131.

Numbers XXIV 17, p. 121.

Deuteronomy I 31, p. 131. XXXII 8 \& 10, p. 131.

II Kings II 9-12, p. 116.

II Maccabees II 21, p. 141. III 24, p. 141.

Job I 6, p. 121.

Psalms II 7-8, p. 74.

XXXI 16, p. 141.

LXXX 6, p. 74.

LXXXIX 26-27, p. 74.

CXVIII 27, p. 141.

Ecclesiasticus IV 11, p. 121.

Isaiah XIV 12-14, p. 121. LXIII 15, p. 131.

Daniel III 15, p. 105.

VII 1-9, p. 51.

IX 31-55, p. 51.

New Testament

Matthew IV 3-6, p. 73.

XI 27, p. 73.

XIV 23, p. 73.

XVI 16, p. 73.

XXI 1-11, p. 84.

XXI 15-16, p. 85.

XXII 16-22, p. 37.

XXVII 39-44, p. 73.

Mark I 1, p. 73.

III 11, p. 73.

V 7, p. 73.

IX 7, p. 73.

XI 8-11, p. 84.

XII 13-17, pp. $37 \& 73$.

XIII 32, p. 73.

XIV 61, p. 73

XV 39, p. 73.
Luke I 35, p. 73.

IV $3 \& 9$, p. 73.

$\mathrm{X} 22$, p. 73.

XIX 28-38, p. 84.

XIX 39-40, p. 85.

XX 25, p. 37.

John I 49, p. 73.

III 17, p. 74.

IV 42 , p. 71.

$\mathrm{X} 36$, p. 73.

XII 12-19, p. 84.

XVIII 36, p. 44.

XIX 12, p. 44.

$\mathrm{XX} 17$, p. 74.

$\mathrm{XX} 28$, p. 63.

XX 31, p. 73.

Acts I 9-11, pp. 131 \& 133.

II 20 , p. 142.

VII 11 f., p. 159.

XII 21-23, pp. 85 \& 86.

XIX 23-41, pp. 86 \& 87.

XXV 11, p. 147.

XXV 25, p. 59.

Romans I 4, p. 73. XIII 1-7, pp. 39 \& 153.

I Corinthians I 7, p. 142.

VI 1, p. 40.

VIII 5-6, p. 63.

II Corinthians II 8, p. 40.

Philippians II 2, p. 63.

II $10-11$, p. 88.

II Thessalonians II 4, p. 52.

Timothy II 2, p. 41. III 6, p. 87. VI 14, p. 143.

II Timothy I 14, p. 143. IV 1, p. 144. IV 8, p. 144.

Titus II 13, p. 143. III 1, p. 43. 
Hebrews IX 28, p. 142.

I Peter II 13-17, p. 42.

I John IV 14, p. 71.

Apocalypse. I 8, p. 90.

I 17, p. 62.

IV 10-11, pp. 53 \& 62.

XI 7, pp. $50 \& 145$.

XI 16, p. 63.

XIII 1 f., p. 50.
XIII 7, p. 145. $\& 112$.

XIII 11-17, pp.86, 96, 104

\section{INDICES}

\section{Greek and Latin Literary Sources}

Appian: 115.

Arrian: 136.

Aurelius Victor: 58, 59.

Augustine of Hippo: 94.

Bede, the Venerable: 52.

Cicero: 28, 30.

Clement of Rome: 151, 152.

Dio: $26,33,34,47,48,55,57,58,77$, $79,80,83,86,92,95,97,98,99,100$, $102,107,108,111,112,118,119$, $120,124,137,152,156$.

Diodorus of Sicily: 66.

Dionysius of Halicarnassus: 64, 66.

Eusebius: 146, 148, 152.

Horace: 76.

Hippolytus: 102, 103.

Jerome: 84, 94.

Josephus: $46,60,68,69,81,82,86$, 110, 111, 156.

Lactantius: 94.

Martial: 139.

Manilius: 138.

Ovid: 138, 153.

Philo: 67, 70, 109, 111, 140.

Pliny (the Elder): 23, 32, 83.

Pliny (the Younger): 79, 98, 112, 146, 154.

Plutarch: $23,24,28,29,65,66,82$, 85, 101, 105, 117, 118, 136.

Polybius: 46.

Seneca: 106, 119, 120.

Servirus: 30.

Statius: 139.

Strabo: 26, 27.
Suetonius: $34,41,45,47,49,55,57$, $73,76,80,82,83,91,92,97,100$, $101,106,108,112,114,117,119$, $120,151,156$.

Tacitus: $27,33,34,47,49,55,56,78$, $83,91,93,99,100,106,107,114$, $149,150$.

Tertullian: 42, 56, 57, 58, 118, 152, 153.

Valleius Paterculus: 122.

Virgil: 28.

Zonaras: 94, 95.

Place Names

Achaia: 93.

Alexandria: 25, 60, 104, 108, 127.

Antioch (Syria): 26.

Artaxata (Neronia): 26.

Assos: 139.

Athens: 65, 67.

Assyria: 24.

Babylon: 24, 121.

Bauli (Baiae): 48.

Bethlehem: 121.

Bithynia: 146.

Bovillaes: 106.

Caesarea: 26, 27, 59, 85, 86.

Carmania: 136.

Cilicia: 27, 28, 29.

Cos: 135.

Cremna: 127.

Cynthus: 95.

Cyzicus: 101.

Dicaearchia: 109.

Egypt: 25, 32, 33, 72, 109, 114, 121.

Ephesus: 86, 87, 101, 102, 136, 137, 155. 
Galatia: 53.

Gaul: 99.

Gischala (Galilee): 66, 81, 133.

Halicarnassus: 64.

Ilium: 23, 26.

Judaea: 27, 48, 59, 110, 114.

Jerusalem: $69,81,91,109,141,155$, 159.

Laodicaea: 101.

Lugdunum: 125.

Miletus: 102.

Mopsuestia: 46.

Naples: 81.

Olympia: 72.

Nicomedia: 154.

Nineveh: 126.

Pannonia: 47.

Paphos: (Augusta): 27.

Pergamum: 27, 34, 72, 101, 102, 157.

Persia: 24.

Philadelphia: 101.

Phoenicia: 126.

Pontia: 152.

Pontus: 146.

Puteoli (Pozzuoli): 48.

Rome: 29, 31, 32, 36, 43, 69, 79, 81, 82, 147, 150, 151, 155, 156.

Samaria (Sebaste): 27.

Sardinia: 156.

Sardis: 101.

Seuleucia (Pieria): 26.

Sichar: 70.

Smyrna: 27, 101, 102, 157, 158.

Spain: 99.

Syria: $48,95$.

Tiberias: 68, 81, 110.

\section{Deities}

Apollo: 28, 64, 72, 73, 77, 79, 80, 102, 113, 114.

Artemis (Diana): 86, 87, 88, 102, 155.

Asclepius: 64.

Athena: 23.

Baals: 124

Castor and Pollux: 108.

Ceres: 123.

Dea Roma: 31, 32, 101, 122, 123.

Deified abstractions: 31, 107.

Dionysus (Bacchus): 25, 136.

Faunus: 28.

Genius: 32.
Harpokrates: 127.

Hera: 24.

Herakles (Hercules): 28, 79.

Hypnos and Thanatos: 129.

Isis: 64, 127, 155, 156.

Jupiter (Zeus): 64, 108, 109, 111, 123, 136, 137, 138, 139, 140.

Jupiter Julius: $76,97$.

Lares: $30,31$.

Latinus: 28.

Manes: 31.

Mars: 77, 120, 121.

Mercury: 137.

Picus: 28.

$\mathrm{Ra}: 72$.

Romulus: 117, 118, 120, 138.

Serapis: 64, 104, 127.

Sol Invictus: 128.

Venus: 119, 121.

\section{General Index}

Acclamations: $52,74,75,78,79,81$, $82,83,84,85,86,88$.

Agrippina: 123.

Alexander : 23, 24, 25, 26, 115, 135, 136.

Altars:

- Ara Pacis: 97.

- Fortuna Redux: 99.

- Pax Augusta: 99, 100.

Antiochus III: 46.

Anti-Christ: 52, 94, 95.

Antigonus: 65.

Antoninus Pius: 101, 125, 128, 161.

Antony: 137.

Apocalypse: passim.

Apotheosis: 29, 116, 120, 121, 122, $123,125,128,129$.

Ascension: 20, 113, 115, 116, 117, 118, $124,126,130,131,132,133,134,140$. Atia: 72, 73, 113.

Augustiani: 77, 78, 79, 80, 101, 111.

Augustus: passim.

Bacchanalia: 155.

Beasts (of the Apocalypse): 96, 97, 104.

Benefactor: $69,81,82$.

Caesar (G. Julius): 30, 31, 38, 39, 42, $44,67,71,72,76,97,115,117,118$, 119, 137, 147. 
- (Friends of -): 44, 45, 46, 48.

- (Worship of -): 42.

Caligula: $39,48,59,67,68,99,100$, $102,105,107,108,109,110,111,120$, 123, 135, 139, 146, 159.

Camillus: 66 .

Cameos:

- Apotheosis of Germanicus: 125, 126.

- Gemma Augustea: 122, 123.

- Grand Camée de France: 123.

Cato (the Younger): 85.

Christ: $35,36,38,40,41,45,48,54$, $62,63,70,79,84,85,115,121,130$, $131,133,134,141,142,-143,144$, 145, 147, 148, 158.

Christian(s): 35, 39, 40, 41, 42, 43, Claudius: $40,48,59,71,120,128,156$.

Commodus: 83, 111.

Demetrius: 65 .

Di Manes: 29, 31.

Divi Filius: 71, 72, 73, 74.

Divus: $38,68,128,129$,

- Augustus: 81, 106, 120, 128.

- Claudius: 73, 128.

- Hadrianus: 125.

- Julius: 31, 34, 73, 121.

- Marcus: 125.

- Vespasianus: 73.

Domitian: $28,39,49,57,58,83,102$, $105,112,139,148,149,152,153$, 154.

Drusus: 47, 99, 123.

Drusilla: 127.

Eagle: 124, 125, 126, 127.

Elvira (Synod of -): 103, 161.

Epiphany (Appearing): 20, 35, 134, 135, 136, 140, 141, 142, 143, 144.

Faustina: 125.

Festus: 59, 61.

Flamen Augustalis: 97.

Flamines: 103.

Titus Flamininus: 66.

Friend (Title of -): 46, 47, 49.

Galba: 49, 82, 90.

Games (Festivals, shows): 102, 103.

Genius (Numen): 31, 32, 33, 37.
Germanicus: 99, 119, 123, 124, 126.

Gracchi: 29, 30, 46.

Herod (Agrippa): 26, 27, 37, 59, 85. Herodes: 61.

Lagids: 45.

Lese-Majesty: 44, 45.

Livia: 34, 100, 120, 123, 128.

Livilla: 123,

Livius Drusus: 46.

Livius Geminius: 127.

Lord (Kyrios): 52, 53, 54, 55, 56, 57, $59,60,61,62,63,70,71.158$.

Lysander: 24.

Maecenas: 76.

Marius: 29.

Mithraism: 157.

Mithridates: 66.

Nero: $39,49,62,75,77,78,79,80,81$, $82,86,88,89,90,91,92,93,94,95$, $99,101,105,111,128,148,149,150$, 151, 153, 154.

Nero Redivivus: 20, 88, 92, 94.

Otho: 82,83 .

Parousia: 134, 141.

Paul (Saint): 36, 39, 40, 41, 42, 43, 52, 59, 63, 158.

Pax Augusta: 67, 100.

Pax Romana: 39.

Persecutions: 21, 145, 146, 148, 149, $150,151,152,153,154,155,159$, 160.

Peter: 42.

Pilate: 44, 45, 48.

Polycarp (Saint): 61, 158.

Pompey: 33.

Preserver: 68.

Priesthood (Priest): 95, 97, 98, 99, 100, 103, 104, 106.

Ptolemies: 25, 32, 136.

Quinquennium Neronis: 39.

Res Gestae: 99.

Rosetta Stone: 26. 
Saviour (Soter): 24, 52, 62, 63, 64, 65, Theos: 25, 27.

$66,67,68,69,70,71,81,82,115$, Tiberius: $33,34,37,38,44,45,47,48$, 131, 143.

Scillitan Martyrs: 61.

Sejanus :48, 100, 107, 119.

Seleucids: $26,45$.

Seleucus VI: 46.

Septemviri Epulones: 100.

Septimius Severus: 155.

Sicarii : $60,61$.

Sodales Augustales: 97, 100.

Statues (Images of the Beast): 104, 105, 106, 107.

Tarquinius: 64.

$55,56,73,99,100,102,105,106$, $107,109,122,123,139,156$.

Timothy : 41.

Titus: 43, 68, 71, 81, 95.

Trajan: 98, 105, 112, 126, 146, 147, 152, 153, 154, 161.

Vespasian: 49, 61, 68, 69, 71, 81, 104, 114.

Vestal Virgins: 99, 100.

Victory: 31, 126.

\section{MODERN SCHOLARS}

Alföldi A.: 128.

Allo E. B.: 19, 64, 90, 96

Babelon E.: 125

Bailey C. : 32, 33

Barclay W.: 96, 121

Bate H. N.: 91, 94

von Baudissin W. W.: 54

Benoît P.: 132

Bernoulli J.: 125

Bevan E.: 25, 45, 46

Bikerman E. : 25, 26, 45

Boismard M. E.: 50

Bömer Fr.: 68

Bouché-Leclercq: 150, 151

Brown R. E.: 50

Brun L.: 50

Bultmann R.: 54, 64

Bureth P.: 59,61

Cabrol F.: 129

Camelot Th.: 61, 158

Canfield L. H.: 148, 152

Cerfaux L.: 19, 43, 53, 72, 135, 137 , 140,142

Chadwick H.: 102

Charbonneaux J.: 98, 122, 123

Charles-Picard G.: 98, 125

Charlesworth M. P.: 24, 29

Cichorius C.: 77

Clair A. St.: 128, 129

Cochrane C. N.: 27

Cullmann O.: 40, 51, 56, 62, 64, 70
Cumont Fr.: 124, 156

Curtius L.: 122, 123

Dalman G.: $38,55,72,73$

Dalton O. M.: 127, 129

Daniélou J.: 130

Deissmann A.: $35,54,58,69,71,72,73$

Delbrück R.: 128, 129

Deonna W.: 55

Dessau H.: 138, 155

Dix G.: 102

von Dobschütz E.: 63

Dodd C. H.: 42, 53

Durrwell F. X.: 131, 132

Eitrem S.: 107

Farrer A.: 50

Farnell L. R.: 25

Festugière A. J.: 55, 56

Fincke A.: 57

Fitzmyer J. A.: 50

Foerster W.: 54

Fossing P.: 126

Fränkel M.: 72

Friedländer L.: 75

Fuller R. H.: 73

Furtwängler A.: 106, 122, 123, 126

Gagé J.: 77, 84, 88, 123

Glasson T. F.: 50

Graeven H.: 128

Grant R. M.: 149 
Green W. M.: 31

Grenfell B.: 59

Gsell S.: 121

Guterman S. L.: 153

Habicht C.: 25, 26

Haerens H.: 64

Hahn F.: 63

Halliday W. R.: 153

Hanson A. T.: 50

Harnack A.: 70

Hefele C. J.: 103

Heinen H.: 72

Héring J.: 39

Herner S.: 54

Herzog R.: 128

Hicks E. L.: 101, 135

Hoffman Lewis: see Lewis $H$.

Homo L.: 146

Hülsen Ch.: 150

Hunt A.: 59

Idris-Bell H.: 155

Jacquier E.: 86, 87, 131

Jucker H.: 124

Kahil L.: 129

Kahler H.: 98

Keil J.: 138

Kennedy H. A. A.: $64,71,96$

Kern O.: 73

Kiddle M.: 89, 96

Kittel G. : 64, 65

Kitzinger E.: 127, 129

Klauser Th.: 75

Kleist J. A.: 86, 151

Koehler L.: 63, 69

Kraus Th.: 98, 122

de Labriolle P.: 146

Lagrange M. J.: 44, 84

Last J.: 146, 149

Leenhardt Fr.: 39

Lewis Hoffman M. W.: 96

Linssen H.: 57

Loesch St.: 39

Loewe H.: 38

Macgregor G. H.: 44

MacKenzie J. L.: 84

MacMullen R.: 75, 89
Magie D.: 26

Maskell A.: 128

Mattingly $\mathrm{H} .: 38,41,118,119,120$, 125, 126

Médébielle A.: 116

Merkelbach R.: 156

Meyer P.: 61

Middleton J. H.: 125

Milligan G.: 141

Mohrmann Ch.: 134, 140

Momigliano A.: 77

Moreau J.: 151

Moretti G.: 97

Morfat J.: 43

Morrison C. D.: 68

Murphy R. E.: 50

Newton C. T.: 101

Nilsson M. P.: 64, 155

Nock A. D.: 25, 50, 62, 64

Nolan B. M.: 142

Owen E. C. E.: 61

Paton W. R.: 135

Pax E.: 142

Perler O.: 79, 84, 130, 135

Peterson E.: 39, 77, 87, 88

Pickard Ch.: 124

Preston R. H.: 50

Prümm K.: 25, 54, 140

Quell G.: 54

Ramsay W. M.: 53, 87

Renan E.: 94

Renié R. P. J.: 131

Richards H.: 53

Rigaux B.: 50, 134, 135, 140, 142.

Rissi M.: 62.

Rodenwaldt G.: 97, 122

Roes A.: 124

Roscher W. H.: 53

Rostovtzeff M.: 34, 77

Rouffiac J.: 67

Ryberg I. Scott: 98

Schillebeeckx E. H.: 131, 132

Schnabel P.: 25

Schonfield H. J.: 86

Scott K.: 104, 105, 114, 135, 138, 153

Selvyn G.: 154

Seyrig H.: 34 
Shervin-White A. N.: 44

Spicq C.: 40, 41, 43, 45, 48, 87, 159

Staerck W.: 64

Stauffer E.: 102

Steinmüller J. E.: 84

Strack P. L.: 125

Sullivan K.: 84.

Sutherland C. H. V.: 125

Sydenham E.: 118, 119, 125

Taeger Fr.: 72, 91

Tarn W. W.: 25

Taylor L. R.: 19, 25, 33, 34

Taylor V.: $71,73,74$

Thieme G.: 69, 73, 134

Tillyard H. J. W.: 88

Tondriau J.: 19, 43, 53, 72, 135, 137, 140

Toynbee J.: 98
Trench R. C.: 55

Tschudin P. F.: 156

Volbach W. F.: 129

Ward M.: 137

Weinstock S.: 98

Wendland P.: 64

Wenger L.: 34

Wessel K.: 128

Sir Wheeler M.: 98

von Wilamowitz-Moellendorff U.: 77

Wilcken U.: 25, 59

Wilhelm A.: 138

Will E.: 122

Windisch H.: 61

Wissowa G.: 156

Workman H. B.: 155, 158

Zucker Fr.: 77 


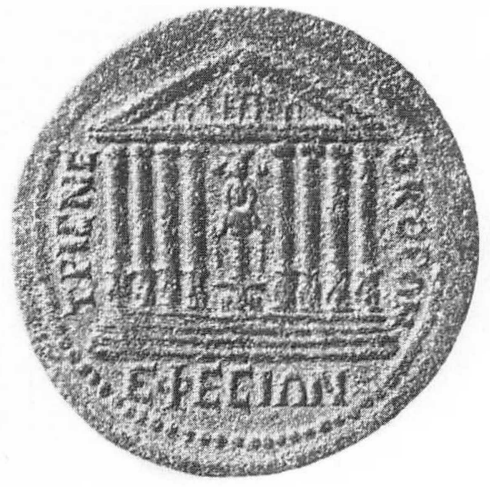

Plate I: p. 86.

Shows the Temple and Statue of Diana. The Inscription reads - "TRIC NEOKOR $\Omega N$ EPHESI $\Omega N »$.

This is uncatalogued. British Museum, 9-9-83 (Acquisition number) 1970. (From the R. E. Hecht Collection, 17.93.)

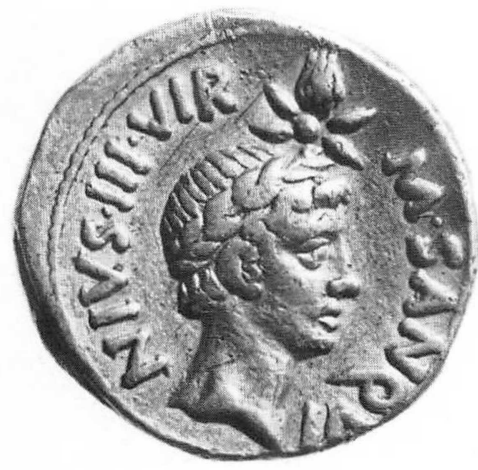

Plate III: p. 118.

Julius Caesar deified. Youthful head, laureate, right. Above, comet with four rays and a tail. Inscription reads - $« \mathrm{M} \cdot \mathrm{SAN}$ QVINIVS.III.VIR».

BMC I Aug. 69. Pl. 2. 19.

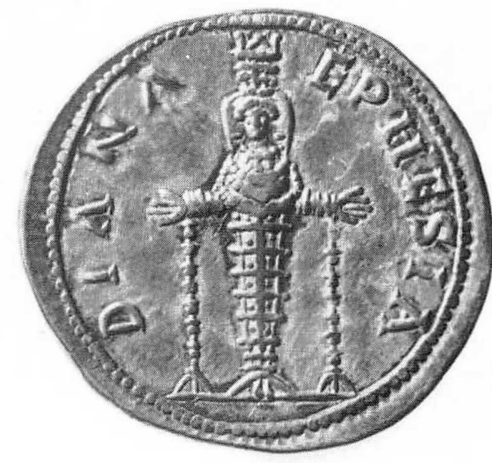

Plate II: p. 86.

A cultus statue of Diana of Ephesus, standing front with arms extended. Inscription reads - "DIANA EPHESIA». Uncatalogued. British Museum, 9-8-1 (Acquisition number) 1968.

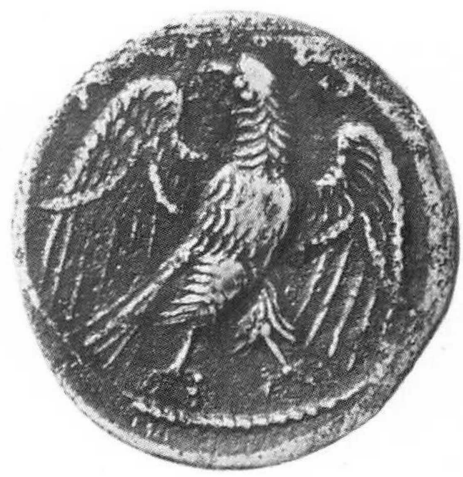

Plate IV: p. 125.

Eagle standing with wings outspread, head turned left.

BMC I Aug. 561. 


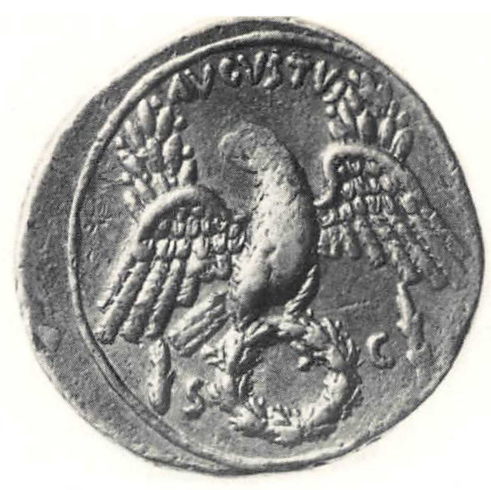

Plate V: p. 125.

Eagle with wings spread, standing front, on an oakwreath, head turned left. Be hind, both left and right, laurel branches. Inscription in the Arc above - «AUGUSTUS » and to left and right of the laurel wreath - «S C». BMC I Aug. 656. Pl. 16.4 (cf. Sutherland, op. cit., p. 32).

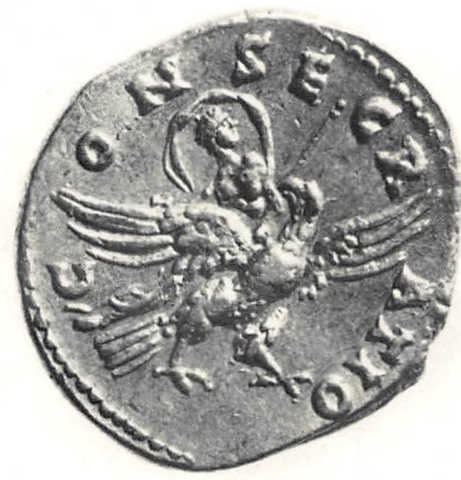

Plate VII: p. 125.

Eagle with wings outspread soaring aloft, right; body, right; head, left. It is carrying Divus Hadrianus on its back. His robe forms a circle round his head and he is holding a sceptre. Inscription reads «CONSECRATIO».

BMC IV 32. Pl. 1.15.

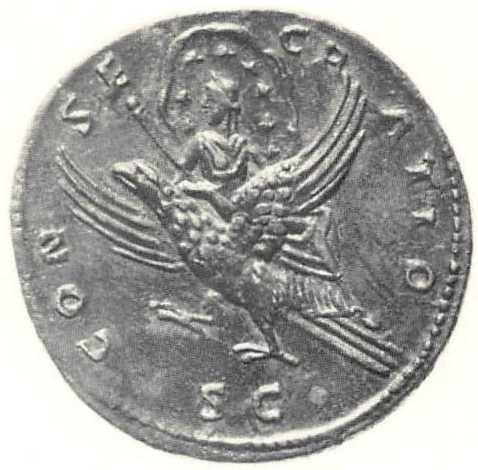

Plate VI: p. 125.

Eagle flying, left. Faustina on its back, holding a sceptre in her right hand.

The Inscription is "CONSECRATIO S C». BMC IV Ant. Pius 1428. Pl. 34.3.

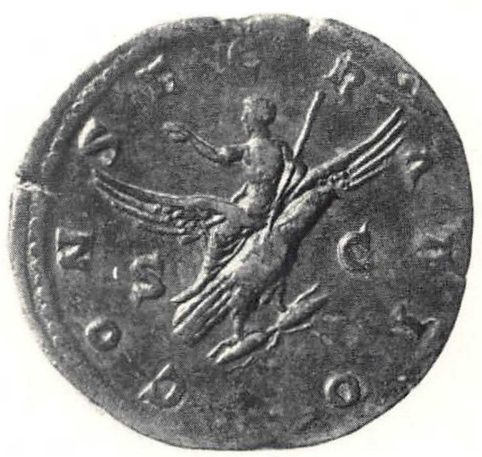

Plate VIII: p. 125.

Eagle with wings outspread, holding a Thunderbolt. Divus Marcus is on its back. Inscription - "CONSECRATIO S C». BMC Commodus No. 394

(cf. also No. 395 Pl.101. 6). 
Plate IX p. 127

"The Apotheosis Diptych", The British Museum.

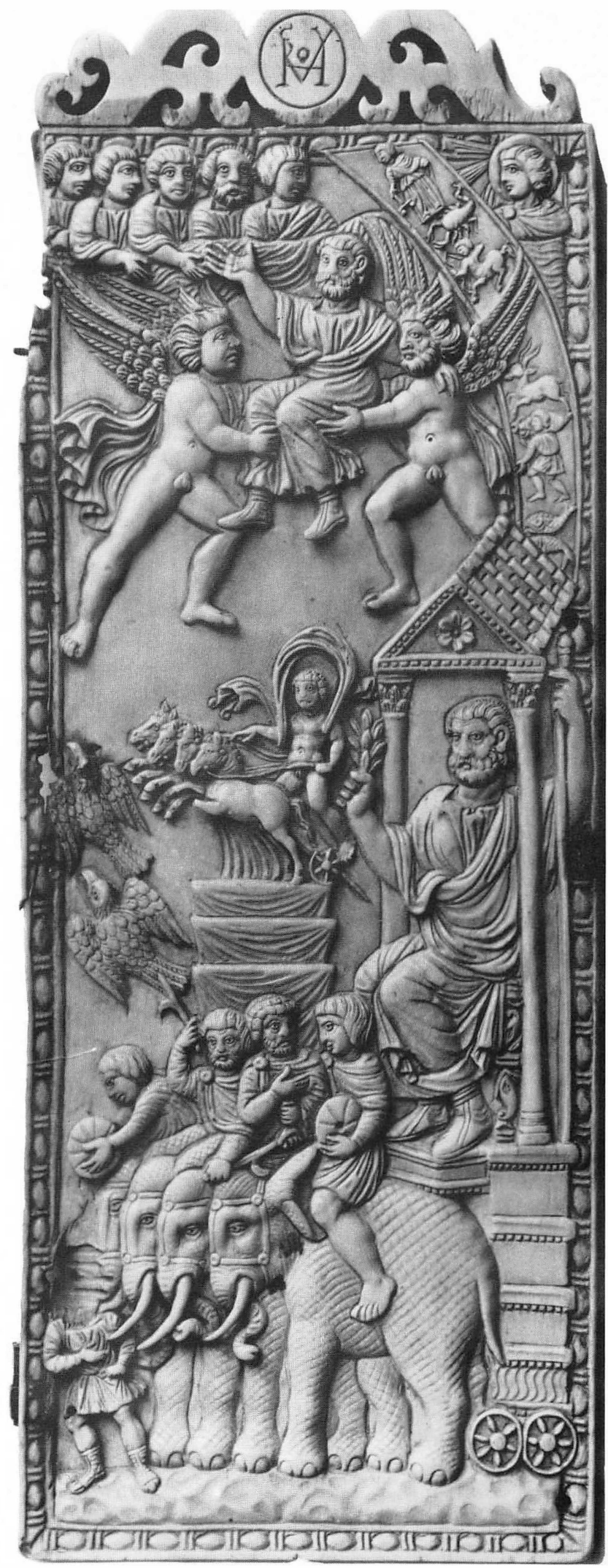


I. Leonhard Weber: Hauptfragen der Moraltheologie Gregors des Großen. Ein Bild altchristlicher Lebensführung. xII-288 S. (1947). vergriffen

II. Andreas Schmid O. S. B.: Die Christologie Isidors von Pelusium. $\mathrm{xx}-114$ S. (1948).

Fr. 9.-

III. Joseph K. Stirnimann: Die Praescriptio Tertullians im Lichte des römischen Rechts und det Theologie. xII-180 S. (1949). vergriffen

IV. KarL Federer: Liturgie und Glaube. Eine theologiegeschichtliche Untersuchung. viri-144 S. (1950).

vergriffen

V. Arors MüLler: Ecclesia-Maria. Die Einheit Marias und der Kirche. 2. überarbeitete Auflage. xviII-242 S. (1955).

Fr. 20.-

VI. Henri de Riedmatten O. P.: Les Actes du Procès de Paul de Samosate. Etude sur la Christologie du IIIe au IVe siècle. 172 p. (1952).

épuisé

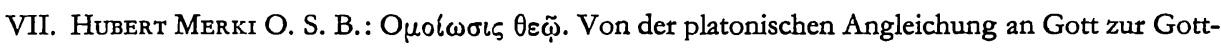
ähnlichkeit bei Gregor von Nyssa. xx-188 S. (1952).

vergriffen

VIII. Othmar Heggelbacher: Die christliche Taufe als Rechtsakt nach dem Zeugnis der frühen Christenheit. IX-196 S. (1953).

vergriffen

IX. Mark Dorenkemper C. PP. S.: The Trinitarian Doctrine and Sources of St. Caesarius of Arles. IX-234 p. (1953).

out of print

X. Tarsicius van Bavel O. E. S. A.: Recherches sur la Christologie de saint Augustin. XIII-189 p. (1954).

épuisé

XI. Luigr I. Scipioni O. P.: Ricerche sulla Cristologia del «Libro di Eraclide» di Nestorio. La formulazione teologica e il suo contesto filosofico. $x-186$ p. (1956).

Fr. 14.-

XII. Gervais Aeby OFM. Cap.: Les Missions Divines. De saint Justin à Origène. XIII-194 p. (1958).

épuisé

XIII. Franz Faessler O. S. B.: Der Hagios-Begriff bei Origenes. Ein Beitrag zum Hagios-Problem. XVIII-242 S. (1958). vergriffen

XIV. Ivo AUf DER MaUr O.S. B.: Mönchtum und Glaubensverkündigung in den Schriften des hl. Johannes Chrysostomus. xvi-205 S. (1959).

Fr. 15.-

XV. Othmar Perler: Ein Hymnus zur Ostervigil von Meliton? (Papyrus Bodmer XI). 96 S. (1960).

Fr. 8.50

XVI. Jean-Louis Maier: Les Missions Divines selon saint Augustin. $\mathrm{x}-226$ p. (1960).

Fr. 18.-

XVII. Charles William Neumann S. M.: The Virgin Mary in the works of Saint Ambrose. xVI-280 p. (1962).

Fr. 22.-

XVIII. Baniero Cantalamessa OFMCap.: La Cristologia di Tertulliano. xIV-213 p. (1962).

Fr. 20.-

XIX. Jean-Louis MaIer: Le Baptistère de Naples et ses mosaĩques. Etude historique et iconographique. xII-175 p. Avec 12 planches (1964).

Fr. 23.-

XX. John Edward Chisholm C. S. Sp.: The Pseudo-Augustinian Hypomnesticon against the Pelagians and Celestians. Vol. I, Introduction. xvi-222 p. (1967).

Fr. 25.-

XXI. John Edward Chisholm C. S. Sp.: The Pseudo-Augustinian Hypomnesticon against the Pelagians and Celestians. Vol. II, The First Critical Edition of the Text.

in preparation

XXII. Dirk Van Damme O. P.: Pseudo-Cyprian, Aduersus Iudaeos. Gegen die Judenchristen. Die älteste lateinische Predigt. xix-200 S. (1969).

Fr. 25.- 


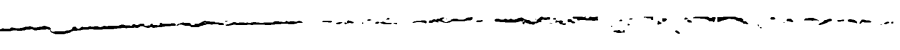

